Florida International University

FIU Digital Commons

FIU Electronic Theses and Dissertations

University Graduate School

7-20-2004

\title{
Distribution and occurrence of inorganic and organic contaminants in sediments and whole fish tissue of Everglades and Biscayne National Parks
}

Adolfo M. Fernandez

Florida International University

DOI: $10.25148 /$ etd.FI15101381

Follow this and additional works at: https://digitalcommons.fiu.edu/etd

Part of the Environmental Sciences Commons

\section{Recommended Citation}

Fernandez, Adolfo M., "Distribution and occurrence of inorganic and organic contaminants in sediments and whole fish tissue of Everglades and Biscayne National Parks" (2004). FIU Electronic Theses and Dissertations. 3346.

https://digitalcommons.fiu.edu/etd/3346 
FLORIDA INTERNATIONAL UNIVERSITY

Miami, Florida

DISTRIBUTION AND OCCURRENCE OF INORGANIC AND ORGANIC

CONTAMINANTS IN SEDIMENTS AND WHOLE FISH TISSUE OF EVERGLADES

AND BISCAYNE NATIONAL PARKS

A thesis submitted in partial fulfillment of the

requirements for the degree of

MASTER OF SCIENCE

in

ENVIRONMENTAL STUDIES

by

Adolfo M. Fernandez 
To: Dean R. Bruce Dunlap

College of Arts and Sciences

This thesis, written by Adolfo Manuel Fernandez, and entitled Distribution and Occurrence of Inorganic and Organic Contaminants in Sediments and Whole Fish Tissue of Everglades and Biscayne National Parks, having been approved in respect to style and intellectual content, is referred to you for judgment.

We have read this thesis and recommend that it be approved.

Piero Gardinali

Gary M. Rand

Rudolf Jaffe, Major Professor

Date of Defense: July 20, 2004

The thesis of Adolfo M. Fernandez is approved.

Dean R. Bruce Dunlap College of Arts and Sciences

Dean Douglas Wartzok University Graduate School

Florida International University, 2004 


\section{DEDICATION}

To my friends and family for always being there. 


\section{ACKNOWLEDGEMENTS}

I would like to thank my major professor, Dr. Rudolf Jaffe for his guidance and patience and for giving me the opportunity for a fulfilling learning experience.

Most importantly, I would like to thank Dr. Piero Gardinali for truly being a mentor to me with all his good-hearted support and understanding and his patience in teaching me the right way to do things and for letting me be a member of his FIU "Family".

I would like to thank Dr. Gary Rand for his encouragement and support throughout my graduate and undergraduate career.

I would also like to thank Dr. Yong Cai for always giving me his time and help.

I would like to thank Dr. William Perry and Dr. Sue Perry of Everglades National Park, for their logistical and financial support for this project. Also, Omar Becerra, Erik Nelson, and Jeff Klein, of the ENP research staff for all their help with my fieldwork.

I Acknowledge DOI-NPS-ENP for funding through the Cooperative Agreement \# 1443CA5280-01-007

I would like to thank Dr. Albert Sabucedo and Myron Georgiadis for their time and help.

I give special thanks to Mark Cejas, Karla Pacheco, Stephanie Cohan, Beatriz Torres, and

Vernon Lawrence for their hard work in helping me with everything. Also Loreta Alvarez, Arlette Azua, Ingrid Zamora, Charles Maxey, Luis Arroyo, Steph Bell, Wu, and Simrat Singh for toiling along side me and giving me reasons to smile, laugh, and yell.

Thanks also to SERC, the Environmental Studies department, and the Chemistry department.

Finally, I thank Eliana Dominguez for always being there and helping me get by. 


\begin{abstract}
OF THE THESIS Whole Fish Tissue of Everglades and Biscayne National Parks

by

Adolfo M. Fernandez

Florida International University, 2004

Miami, Florida

Professor Rudolf Jaffe, Major Professor
\end{abstract}

Distribution and Occurrence of Inorganic and Organic Contaminants in Sediments and

This study provides a detailed survey of the presence, concentration levels, and spatial distribution of organic and inorganic contaminants in sediment and tissue samples collected within Everglades and Biscayne National Parks. The results of these analyses revealed elevated concentrations of arsenic, and lead and chromium in Everglades National Park (ENP) sediments exceeding Potential Effects Levels (PEL) in 9,5 and $5 \%$ of sediment samples and concentrations of nickel exceeding Threshold Effects Levels (TEL) in 5\% of samples. In Biscayne National Park, arsenic exceeded TEL in $44 \%$ of sediment samples. Organic analyses of ENP sediments revealed elevated concentrations of DDT and its metabolites in $5 \%$ of the samples. Fish tissue analysis indicate that Endosulfan may pose a hazard in aquatic environments due to its high frequency of detection, Endosulfan sulfate in $85 \%$ and $\beta$-Endosulfan in $5 \%$ of samples. 


\section{TABLE OF CONTENTS}

CHAPTER

PAGE

1. INTRODUCTION 1

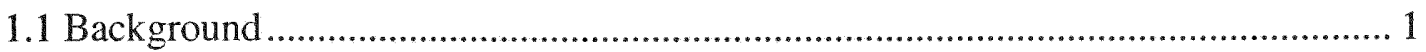

1.2 Fate of Hydrophobic Organic Contaminants in the Aquatic Environment .............. 4

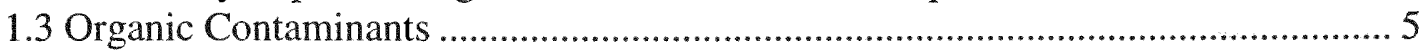

1.3.1 Organochlorine Pesticides ............................................................................ 5

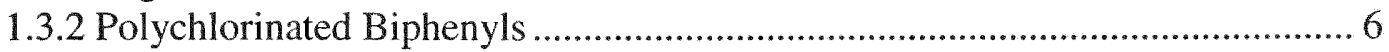

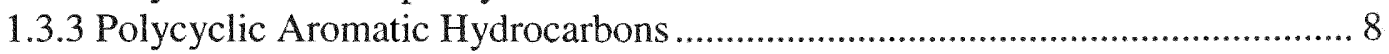

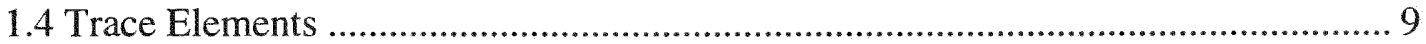

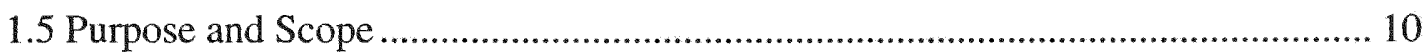

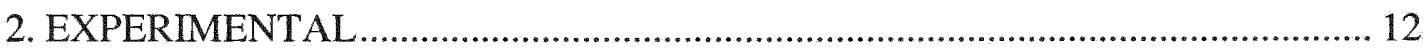

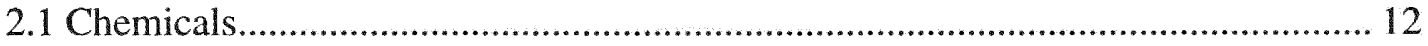

2.2 Sampling Strategy and Site Locations ............................................................. 12

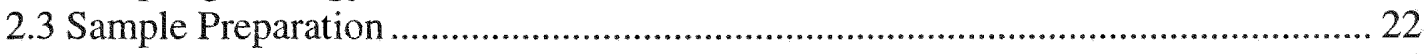

2.3.1 Dry Weight Determination of Sediments ....................................................... 22

2.3.2 Organic Matter Determination of Sediments .................................................. 22

2.3.3 Sediment Grain Size Analysis........................................................................... 23

2.3.4 Sediment preparation for ICP-MS determination of Metals .......................... 24

2.3.5 Sediment preparation for GC-ECD determination of Organochlorine

Pesticides, PCBs, and GC-MS determination of PAHs........................................... 25

2.3.6 Percent Dry Weight Determination of Tissue.................................................. 26

2.3.7 Determination of Percent Lipid in Tissue ..................................................... 27

2.3.8 Fish tissue preparation for GC-ECD determination of Organochlorine

Pesticides, PCBs, and GC-MS determination of PAHs........................................... 28

2.3.9 Preparation of fish tissue samples for ICP-MS determination

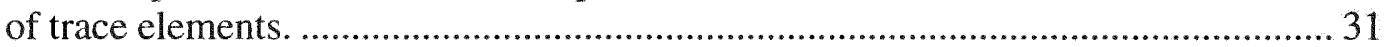

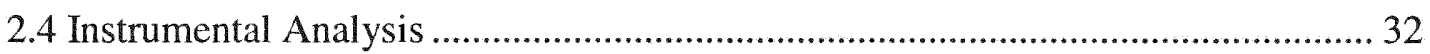

2.4.1 Organochlorine Pesticide and PCB determination by GC-ECD ..................... 32

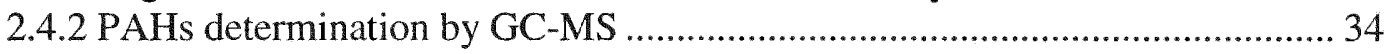

2.4.3 Trace and Major Element Determination by ICP-MS .................................... 37

2.4.3.1 ICP-MS determination of sediment samples ............................................. 38

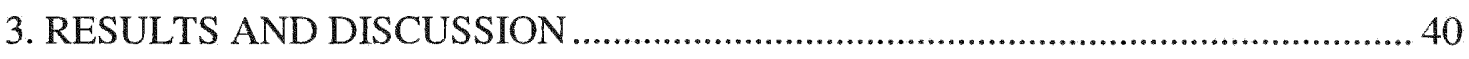

3.1 Sediment Contamination Assessment .................................................................. 40

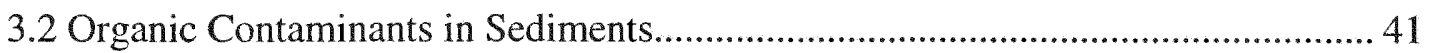

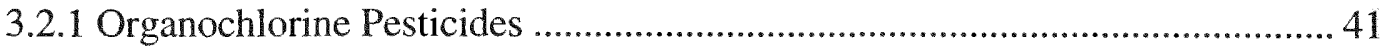

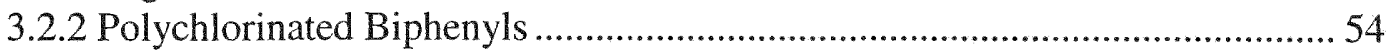

3.2.3 Polycyclic Aromatic Hydrocarbons ................................................................. 57

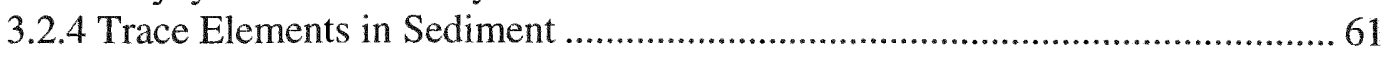


3.3 Organic Contaminants in Whole Fish Tissue Samples......................................... 86

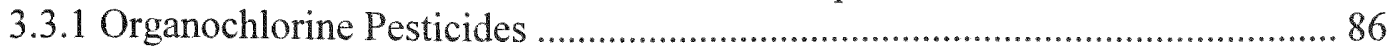

3.3.2 Polychlorinated Biphenyls ......................................................................... 95

3.3.3 Polycyclic Aromatic Hydrocarbons ........................................................... 97

3.4 Trace Elements in Whole Fish Tissue Samples ............................................. 101

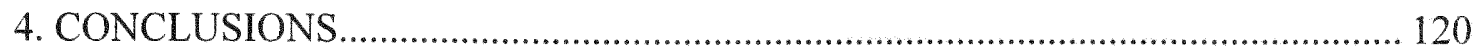

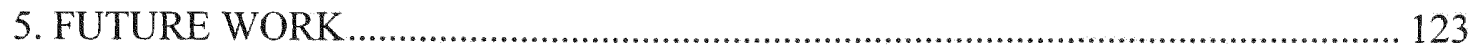

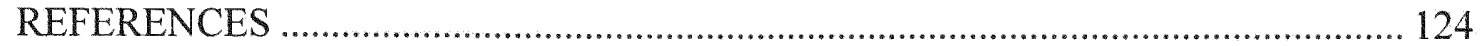

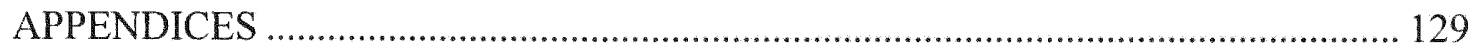




\section{LIST OF TABLES}

TABLE

PAGE

Table 1.- Locations of Sediment Sample Stations in Everglades National

Park.

Table 2.-Locations of Sediment Sampling Stations in Biscayne National Park

and Florida Bay.

Table 3.-Locations of Fish Sampling Stations In Everglades National Park and Florida Bay.

Table 4.- Organochlorine Pesticides and Polychlorinated Biphenyls of interest.

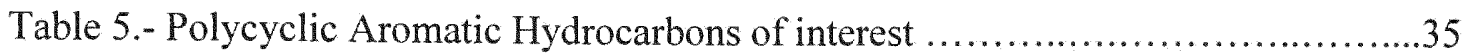

Table 6.-Trace and Major Elements of interest...................................... 38

Table 7.-Concentrations of Organochlorine Pesticides and Polychlorinated

Biphenyls in Sediment samples.

Table 8.-Concentrations of Polycyclic Aromatic Hydrocarbons

in Sediment samples.

Table 9.-Concentrations of Trace and Major Elements in Sediment samples.

Table 10.-Concentrations of Organochlorine Pesticides and Polychlorinated Biphenyls in Tissue samples.

Table 11.-Concentrations of Polycyclic Aromatic Hydrocarbons

in Tissue samples

Table 12.-Concentrations of Trace and Major Elements in Tissue samples. 


\section{LIST OF FIGURES}

FIGURE

PAGE

Figure 1.-Map of ENP sediment sample stations.................................14

Figure 2.-Map of BNP sediment sample stations...................................17

Figure 3.-Map of Florida Bay sediment sample stations..............................18

Figure 4.-Map of ENP and Florida Bay fish sample stations.........................21

Figure 5.-Ranked concentrations of p-p'DDT in ENP sediment.........................43

Figure 6.-Ranked concentrations of p-p'DDD in ENP sediment ...................43

Figure 7.-Ranked concentrations of p-p'DDE in ENP sediment .......................44

Figure 8.-Ranked concentrations of Dieldrin in ENP sediment .......................44

Figure 9.-Spatial distribution of p-p'DDT in ENP sediment..........................45

Figure 10.-Spatial distribution of p-p'DDE in ENP sediment ........................46

Figure 11.-Spatial distribution of Endosulfan Sulfate in ENP sediment.................48

Figure 12.-Ranked concentrations of Endosulfan Sulfate in ENP sediment..............49

Figure 13.-Boxplot graph of total DDT distribution within study area.................52

Figure 14.-Boxplot graph of p-p'DDE distribution within study area....................52

Figure 15.-Boxplot graph of o-p'DDE/ $\alpha$-endosulfan distribution within study area.......53

Figure 16.-Boxplot graph of Endosulfan sulfate distribution within study area...........53

Figure 17.-Spatial distribution of Polychlorinated Biphenyls ..........................55

Figure 18.-Box plot graph of total PCB distribution within study area....................56

Figure 19.-Spatial distribution of total PAHs in sediment samples......................59

Figure 20.-Box plot graph of total PAH distribution within study area..................60

Figure 21.-Ranked concentrations of lead in ENP sediments.......................64 
Figure 22.-Ranked concentrations of chromium in ENP sediments....................64

Figure 23.-Ranked concentrations of arsenic in ENP sediments......................65

Figure 24.-Ranked concentrations of nickel in ENP sediments......................65

Figure 25.-Ranked concentrations of arsenic in BNP sediments.......................66

Figure 26.-Spatial distribution of arsenic in sediment samples .......................67

Figure 27.-Spatial distribution of beryllium in sediment samples......................68

Figure 28.-Spatial distribution of chromium in sediment samples......................69

Figure 29.-Spatial distribution of cobalt in sediment samples.........................70

Figure 30.-Spatial distribution of copper in sediment samples..........................71

Figure 31.-Spatial distribution of lead in ENP sediments...............................72

Figure 32.-Spatial distribution of nickel in sediment samples..........................73

Figure 33.-Spatial distribution of vanadium in sediment samples......................74

Figure 34.-Spatial distribution of zinc in sediment samples.......................... 75

Figure 35.-Concentrations of arsenic vs. aluminum in ENP sediments..................77

Figure 36.-Concentrations of chromium vs. aluminum in ENP sediments...............77

Figure 37.-Concentrations of copper vs. aluminum in ENP sediments.................78

Figure 38.-Concentrations of nickel vs. aluminum in ENP sediments..................78

Figure 39.-Concentrations of lead vs. aluminum in ENP sediments...................79

Figure 40.-Concentrations of zinc vs. aluminum in ENP sediments...................79

Figure 41.-Concentrations of arsenic vs. aluminum in BNP sediments ................80

Figure 42.-Distribution of Beryllium concentrations within study area..................81

Figure 43.-Distribution of Vanadium concentrations within study area................8 82

Figure 44.-Distribution of Chromium concentrations within study area.................82 
Figure 45.-Distribution of Cobalt concentrations within study area...................83

Figure 46.-Distribution of Nickel concentrations within study area...................83

Figure 47.-Distribution of Copper concentrations within study area.....................84

Figure 48.-Distribution of Zinc concentrations within study area.....................84

Figure 49.-Distribution of Arsenic concentrations within study area...................85

Figure 50.-Distribution of Lead concentrations within study area......................85

Figure 51.-Spatial distribution of p-p'DDE detected in fish tissue samples..............88

Figure 52.-Spatial distribution of Endosulfan sulfate detected in fish tissue samples......89

Figure 53.-Distribution of total DDT concentrations in fish within study area............90

Figure 54.-Distribution of p-p'DDE concentrations in fish within study area............91

Figure 55.-Distribution of Endosulfan Sulfate concentrations in fish within study area............................................................. 91

Figure 56.-Spatial distribution of estimated water concentrations of endosulfan sulfate based on fish tissue concentrations.......................94

Figure 57.-Distribution of Total PCBs concentrations in fish within study area...............................................................

Figure 58.-Spatial distribution of total PCBs detected in fish tissue samples.............96

Figure 59.-Spatial distribution of total PAHs detected in fish tissue....................99

Figure 60.-Distribution of total PAH concentrations in fish within study area............100

Figure 61.-Spatial distribution of arsenic in whole fish tissue $\ldots \ldots \ldots \ldots \ldots \ldots \ldots \ldots \ldots \ldots$

Figure 62.-Spatial distribution of beryllium in whole fish tissue .....................104

Figure 63.-Spatial distribution of cadmium in whole fish tissue........................105

Figure 64.-Spatial distribution of cobalt in whole fish tissue...........................106

Figure 65.-Spatial distribution of chromium in whole fish tissue.....................107 
Figure 66.-Spatial distribution of copper in whole fish tissue.........................108

Figure 67.-Spatial distribution of lead in whole fish tissue............................109

Figure 68.-Spatial distribution of nickel in whole fish tissue ..........................110

Figure 69.-Spatial distribution of silver in whole fish tissue..........................111

Figure 70 -Spatial distribution of vanadium in whole fish tissue......................112

Figure 71.-Spatial distribution of zinc in whole fish tissue............................113

Figure 72.-Distribution of arsenic concentrations in fish within study area.............114

Figure 73.-Distribution of beryllium concentrations in fish within study area...........114

Figure 74.-Distribution of chromium concentrations in fish within study area..........115

Figure 75.-Distribution of cobalt concentrations in fish within study area.............115

Figure 76.-Distribution of copper concentrations in fish within study area............116

Figure 77.-Distribution of lead concentrations in fish within study area...............116

Figure 78.-Distribution of nickel concentrations in fish within study area..............117

Figure 79.-Distribution of silver concentrations in fish within study area..............117

Figure 80.-Distribution of vanadium concentrations in fish within study area..........118

Figure 81.-Distribution of zinc concentrations within in fish study area..............118 


\section{INTRODUCTION}

\subsection{Background}

South Florida is in the process of undergoing the largest environmental restoration project in the history of the United States, namely, the Comprehensive Everglades Restoration Project (CERP). The CERP priorities include altering the system's hydrology in order to improve the quality, quantity, and timing of water flows into and throughout the Everglades. The project addresses water quality issues, specifically the effects of increased levels of nutrients and mercury on the structure and function of ecosystems in the Everglades region. While these and other aspects of troubled ecosystems in South Florida have been identified, many others are still being investigated. Little consideration has been given in the restoration effort to the role that pesticides and other organic and inorganic contaminants play in the structure and function of ecosystems in the Everglades although this is clearly a recommendation of the Science Subgroup (1996) in all physiographic regions that comprise South Florida.

The need to fill the void with more information on chemical contaminants in the Everglades gains in importance since an increasing number of anthropogenic contaminants are capable of disrupting endocrine function in vertebrate and invertebrate wildlife. Pollutants such as trace metals, PCBs, organochlorine pesticides, PAHs and others, can reach these aquatic environments through atmospheric transport, agricultural, industrial, municipal and tourism-related activities. However, limited information is available about the presence and the levels of such pollutants within Everglades National Park. This study presents preliminary data on eleven major and trace metals, PCBs, 
organochlorine pesticides and PAHs in sediments and tissue samples from Everglades, and Biscayne National Parks, and discusses their environmental significance.

Most monitoring studies in South Florida have focused on concentrations of contaminants present in different environmental compartments (exposure assessment). For example, the South Florida Water Management District (SFWMD) began monitoring pesticides in water and bottom sediment in South Florida canals in the mid 1980's (Pfeuffer, 1985, 1991). Recent sediment and water analyses in South Florida by SFWMD indicate that atrazine, ametryn, bromacil, simazine, diuron, alpha-endosulfan, beta-endosulfan, endosulfan sulfate, ethion, hexazinone and norflurazon were the most frequently detected pesticides in surface water. While DDE, DDD, ametryn, atrazine, dicofol, diquat, and endosulfan sulfate were the most frequently detected pesticides in sediment samples between 1991 and 1995 (Miles and Pfeuffer, 1997).

Several of the SFWMD sampling sites were located in the Everglades Agricultural Area (EAA) and others were in the Homestead Agricultural Area (HAA) adjacent to Everglades National Park. At most sampling sites for water and sediment more than one pesticide was detected in each sample. The U.S. Geological Survey (U.S.G.S.) through its National Water Quality Assessment (NAWQA) program is also measuring the occurrence of pesticides in water, sediment and fish. Recent analysis of fish (i.e. largemouth bass, Florida gar) collected in 1995 show that concentrations of organochlorine residues including DDT and its degradation products (p,p'-DDE) have remained prevalent in freshwater fish and are similar to measurements in the early 1970's in canals of the northern Everglades (Haag and McPherson, 1997). PCBs were not as frequently detected in 1995 as in the 1970's but concentration ranges were similar. 
One study conducted as part of the National Oceanic and Atmospheric Administration (NOAA) Status and Trends Program (Long, E. et al. 1999) surveyed the toxicity of Biscayne Bay sediments collected from a large number of samples (226). For this study, a suit of toxicity tests were conducted on all samples collected as well chemical analysis for the presence of chlorinated pesticides, polychlorinated biphenyls, polycyclic aromatic hydrocarbons, and trace elements. The results of this study revealed that the levels of toxicity and chemical contamination are similar to or less severe than the national average based upon previous NOAA studies. However, several contaminants appear at elevated concentrations, these include DDT and its metabolites, PCBs, and trace elements including copper, lead, mercury, cadmium and zinc.

These studies, however, do not provide a comprehensive assessment of the levels of these contaminants over a wide geographic range nor do they employ consistent methods of analysis upon uniform matrices. This research project represents one of the first investigations to define pesticide, $\mathrm{PCB}, \mathrm{PAH}$, as well as major and trace metal distributions, and their toxicological implications and hazard to ecological receptors in the Everglades and Biscayne National Parks. This study area will focus on sites within Everglades National Park (ENP) as well as sites within Biscayne National Park (BNP). The data generated from this study will form the basis for the initial phase (hazard identification) of an ecological risk assessment under the USEPA framework and it will provide a scientific information base to meet some of the goals/objectives of the South Florida Ecosystem restoration effort recommended in the science plan by the interagency Science Subgroup (1996). 
This project has relevant and significant scientific merit because of the wide scale uses of pesticides in South Florida, the documented levels of detectable pesticide residues in soil, water, sediment and biota, the limited data on pesticide, PCB, PAH and trace element exposure, and biological effects in the Everglades and the known sensitivity of various organisms to these organic contaminants. Additionally, wide-scale changes in the hydrology of the Everglades system resulting from proposed CERP projects may have a significant impact on the presence, transportation, and availability of certain contaminants.

\subsection{Fate of Hydrophobic Organic Contaminants in the Aquatic Environment}

Sediments are complex mixture of materials, which are comprised of detritus, inorganic and organic particles, and are relatively heterogeneous in terms of physical, chemical and biological characteristics. Sediments are regarded as the ultimate sink for persistent pollutants discharged into the environment and are one of the best media for the long-term monitoring of many contaminants. In addition, due to various diagenetic processes, sediment-bound metals and other pollutants may remobilize and be released back to overlying waters and in turn impose adverse effects on terrestrial and aquatic organisms ( $\mathrm{Li}$ et al., 2000). Sediment quality investigations conducted by NOAA and the Florida Department of Environmental Protection (FDEP) have indicated that toxic chemicals are found in the sediments and biota of Florida estuaries (NOAA, 1997) which resulted in the promulgation of Sediment Quality Assessment Guidelines (SQAQ'S) used to assess the environmental quality of coastal areas and embayment (McDonald, 1994). 
In addition to soil and sediment analysis, chemical analysis of fish tissue is a useful tool for assessing the magnitude of contamination of certain pollutants within a region. Contaminants such as chlorinated pesticides and PCBs are hydrophobic and tend to accumulate in the lipid tissue of living organisms. Different processes affect the accumulation of persistent hydrophobic chemicals in aquatic organisms (Jaffe 1991). The uptake of these chemicals directly from the environment through the gills or by direct contact with skin is a process known as bioconcentration. Uptake through the ingestion of contaminated biota is referred to as biomagnification. An important parameter necessary for the assessment of contamination through these processes is the bioavailability of a contaminant. Bioavailability is defined as the fraction of the total bulk of a substance in the environment that can be potentially taken up by an organism during its lifetime. Since soils and sediments are the ultimate sinks for such contaminants, their characteristic properties such as organic matter content and particle size distribution are important factors in determining the bioavailability of these substances (Jaffe 1991, Van der Oost 2003).

\subsection{Organic Contaminants}

\subsubsection{Organochlorine Pesticides}

Organochlorine pesticides (OCPs) are an important group of contaminants of concern in the South Florida region because of its extensive history of intensive agriculture. It is estimated that 14,590 tons of pesticides are applied in south Florida each year (Miles and Pheuffer, 1997). OCPs such as DDT, methoxychlor, chlordane, aldrin, dieldrin/endrin, heptachlor and endosulfan were introduced as pest control agents after 
the Second World War (Manahan, 2000). Their high toxicity against insects made them very popular insecticides and their use spread widely in the following decades. However, most of these compounds are very stable against decomposition or degradation in the environment, they have very low solubility in water, and they are highly soluble in hydrocarbon-like environments, such as the fatty material in living matter (Baird 1999).

The properties of OCPs make them environmentally persistent globally and they are thus, exerting chronic-toxic effects on wildlife and humans (Logananthan, 1994). OCPs are released locally into the environment during application through agricultural runoff, leaching and aerial spray drift. They are also transported globally via the atmosphere resulting from volatilization from soil and crops (Hites 1987). Once in the atmosphere, OCPs can be deposited in remote areas in the form of wet or dry deposition (Van Dijk and Guicherit, 1999, Hites 1987). Although most OCPs were banned in the US in the 1970's due to their toxicity, persistence, and tendency to bioaccumulate, they continue to be detected in water, sediment and aquatic biota through out the world (Sapozhnikova and Schlenk, 2004).

\subsubsection{Polychlorinated Biphenyls}

Polychlorinated Biphenyls (PCBs) are common sediment pollutants. PCBs comprise a class of 209 nonpolar, chlorinated hydrocarbons with a biphenyl nucleus on which one to ten of the hydrogen atoms have been replaced by chlorine atoms. The entire set of 209 PCBs forms a set of congeners. When PCBs are subdivided by degree of chlorination, the term homolog is used, e.g., trichlorobiphenyl homologs. PCBs of a given homologous group with a different chlorine substitution position pattern are called 
isomers e. g. 2,3,4-trichlorophenyl and 3,3',5-trichlorobiphenyl are two of the twelve trichlorobiphenyl isomers (Erickson, 1997).

Commercial PCBs were manufactured and sold as complex mixtures containing multiple isomers with different degrees of chlorination. PCBs have low water solubility, low vapor pressures, and are soluble in most organic solvents, oils, and fats. PCBs are very stable compounds and do not degrade easily (Erickson, 1997). Because of their lipophilic characteristics and their persistence, they also tend to bioaccumulate (Erickson, 1997). Although use of PCBs has been banned or restricted in most industrial countries, environmental levels are only slowly decreasing (Wania, and Daly, 2002).

PCBs are extremely persistent to chemical and biological degradation and are highly hydrophobic, thus, they tend to accumulate in sediments adsorbed on small particles (Van der Oost, 1996). More than $90 \%$ of the environmental burden of PCBs is found in soil and sediments (Cousins et al., 1999). Consequently, soils and sediments which once acted as a sink for these compounds have become a source volatilizing PCBs back to the atmosphere (Cousins et al., 1998). The environmental transport of PCBs is complex and global. Volatilization of PCBs from spills, landfills, road oils, and other sources results in measurable atmospheric emissions. Atmospheric transport is the primary mode of global distribution of PCBs. Environmental levels of PCBs increase near their sources, thus urban areas have generally higher concentrations than pristine environments. PCBs are considered ubiquitous pollutants found in nearly all marine plant and animal specimens including, fish, mammals, birds (especially piscivorous species), bird eggs, and, of course humans. 
1.3.3 Polycyclic Aromatic Hydrocarbons

Polycyclic Aromatic Hydrocarbons (PAHs) are another group of ubiquitous organic contaminants present in coastal marine sediments. The distribution and fate of PAHs in aquatic systems has received much attention due to their mutagenic and carcinogenic effects (Grimmer, 1983) and their demonstrated impact on ecosystems (Neff, 1979). Due to their highly hydrophobic and stable chemical structure, PAHs are not very soluble in the water phase but sorb rapidly and strongly onto particles (Sheedy et al., 1998). The strong adsorption of PAHs on sediment particles could reduce their bioavailability, reducing their biodegradation rates and preserving them in sediments. PAHs are efficiently metabolized by phase I enzymes in fish liver resulting in low clearance time and therefore due not tend to bioaccumulate in fish tissue (Van der Oost, et al., 2003).

PAHs are components of fossil fuels such as coal and oil and they are produced in the combustion of organic matter. The occurrence of PAHs in coastal sediments is well documented and mainly due to both natural and anthropogenic sources (Buehler et al., 2001). Among these, pyrogenic, (mainly combustion of fossil fuel and vegetation), and petrogenic (petroleum products) inputs are the two main sources (Jones, 1989). It has been estimated that on a global scale, the distribution of PAHs in contemporary aquatic environments is dominated by input from pyrogenic sources mainly from anthropogenic combustion processes. Studies have shown that PAHs from pyrogenic and petrogenic sources exhibited different chemical behaviors and distributions in marine sediments (Mastral, 2002). For example, PAHs from pyrogenic sources tend to be more strongly associated with sediment and soot particles and more resistant to microbial degradation 
than PAHs from petrogenic sources (Wang, 2001). Lang, et al. (2002) conducted a study in the Miami area to identify and characterize the distribution of PAHs in the atmosphere. The results of this study indicate that automobile exhaust is the predominant emission source for atmospheric PAHs in this area, while other sources such as waste incineration, power plants, and biomass combustion contribute a lesser fraction. Based on these results and the increasing population and urbanization of the south Florida area, an increase of PAH deposition in the Everglades Region can be expected.

\subsection{Trace Elements}

Trace metals such as lead, cadmium and arsenic are naturally present in the environment at very low levels. Some of these, such as copper and zinc, are required as nutrients for plants and animals at very low concentrations, but at enriched levels can be toxic (Papagiannis 2004, Barwick 2003). Trace elements are a considerable environmental hazard due to their extensive use, toxicity, widespread distribution, and environmental persistence. Metals are for the most part transported from place to place via the atmosphere, as gases or as species adsorbed on or absorbed in suspended particulate matter. The ultimate sinks for metals are soils and sediments (Baird, 1999).

In South Florida, trace metal contamination can be attributed to both local and regional sources as well as trans-oceanic transport i.e. African dust (Dvonch et al., 1999; Graney et al., 2004; Holmes and Miller, 2004). Specifically, local sources include municipal solid waste incineration facilities, with emissions characterized by elevated concentrations of zinc, lead, mercury, chlorine, and bromine (Graney et al., 2004). Oil fired power plants, which are common in south Florida are associated with emissions of 
Vanadium and Nickel (Graney et al., 2004; Dvonch et al., 1999). Additionally, substantial amounts of particulate material containing zinc, lead, and copper, have been found in emission from municipal and medical waste incineration and cement production facilities (Graney et al., 2004). Global transport is another important source of trace metal contamination in south Florida, with African dust accounting for about $25 \%$ of arsenic deposition (Holmes and Miller, 2004). In South Florida, mercury contamination has received much attention due to the elevated concentrations detected in water, sediments, soils, and biota at various trophic levels (USEPA 2002). Although mercury contamination will not be addressed in this study, its presence as a trace element contaminant should be taken into consideration when discussing the distribution of other trace elements in the study area.

\subsection{Purpose and Scope}

Due to the extensive development, persistence of intensive agriculture in southeast Florida, and the presence of sediment and tissue contaminants in other south Florida localities, a complete assessment of the sediment quality of the Everglades watershed was conducted.

The main objectives for the study are as follows:

- Provide a detailed survey of the presence, concentration levels, and spatial distribution of organic and inorganic anthropogenic contaminants in sediments and whole fish tissue collected within the Everglades and Biscayne National Parks. 
- Establish the potential hazard associated by the presence of common contaminants using Sediment Quality Assessment Guidelines (SQAGs).

- Development of a chemical-toxicological information base that will assist in filling existing data gaps and managing the South Florida Ecosystem restoration efforts.

- Identify sites within ENP and BNP where additional monitoring should be considered. 


\section{EXPERIMENTAL}

\subsection{Chemicals}

Water $\left(\mathrm{H}_{2} \mathrm{O}\right)$, dichloromethane $\left(\mathrm{CH}_{2} \mathrm{Cl}_{2}\right)$, pentane $\left(\mathrm{C}_{5} \mathrm{H}_{12}\right)$, hexane $\left(\mathrm{C}_{6} \mathrm{H}_{14}\right)$ of pesticide grade or equivalent, hydrogen peroxide $\left(\mathrm{H}_{2} \mathrm{O}_{2}\right)$, and nitric acid $\left(\mathrm{HNO}_{3}\right)$, hydrochloric acid $(\mathrm{HCl})$ of trace metal grade, and silica gel (60 mesh), alumina, sodium sulfate $\left(\mathrm{Na}_{2} \mathrm{SO}_{4}\right)$, sand, fiber glass, and metallic copper $(\mathrm{Cu})$ were obtained from Fisher Scientific (Fair Lawn, NJ). All chemicals were used as received with the exception of anhydrous sodium sulfate, sand, glass fiber, which were combusted at $450{ }^{\circ} \mathrm{C}$ for 4 hours. The silica was activated in the oven at $170^{\circ} \mathrm{C}$ for $16 \mathrm{hrs}$.

Standards of all the contaminants analyzed were purchased from different companies such as Supelco, Chem service, and Ultra scientific. Standards used for the trace metal analysis were obtained from GFS chemicals

\subsection{Sampling Strategy and Site Locations}

The sampling strategy for the project was based on the assumption that regions of the Everglades National Park (ENP) located near the Homestead Agricultural Area are more prone to chemical residue deposition, exposure and adverse effects than more remote areas. A list of sampling locations and dates for ENP is given in table 1. The first sediment-sampling event for Everglades National Park was performed between August and September of 2001. A map of ENP sediment sample stations is given in figure 1 . Samples were collected from 5 transects. The first transect follows an east-west direction across the northern boundary of the park which receives water from the Water 


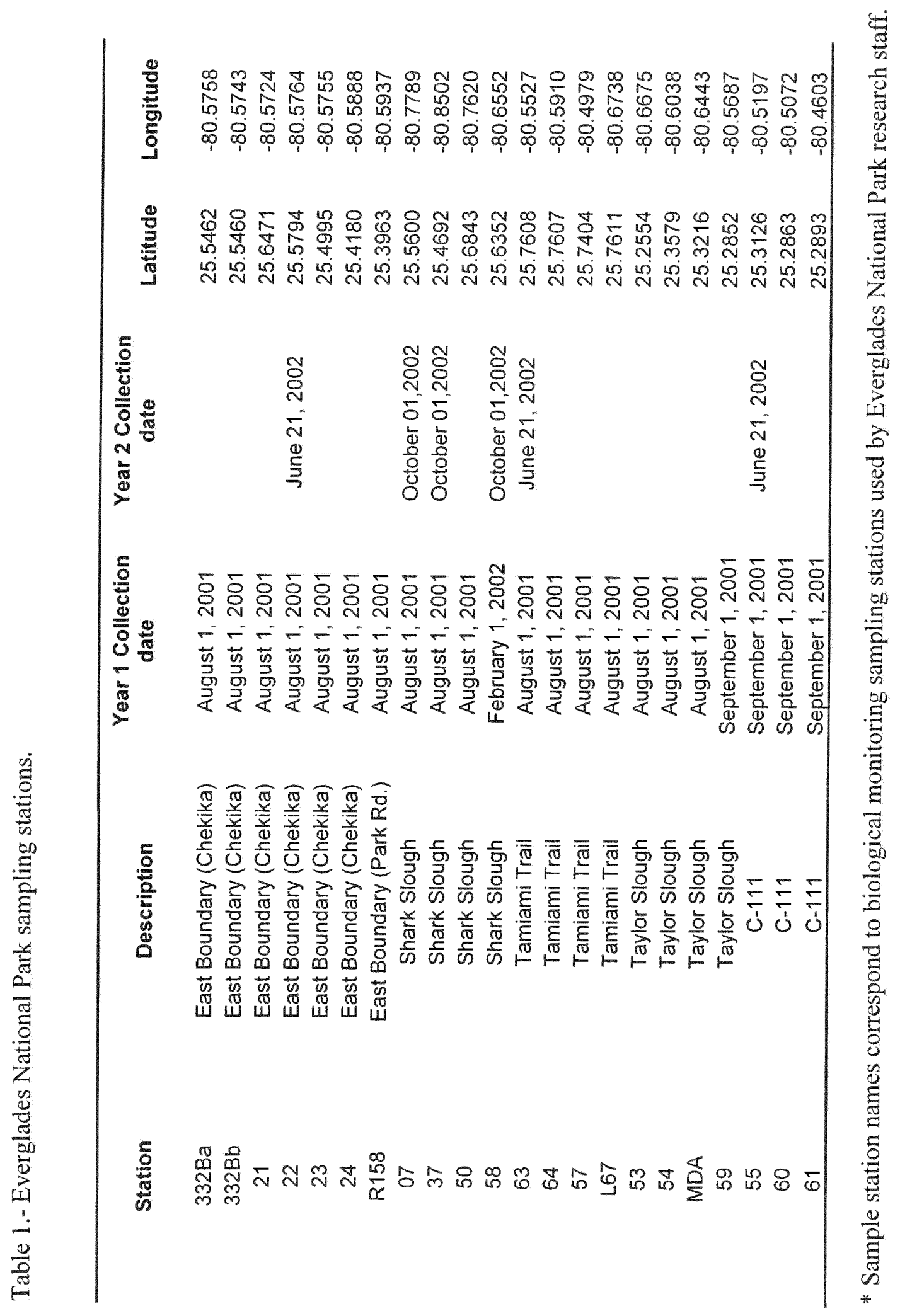




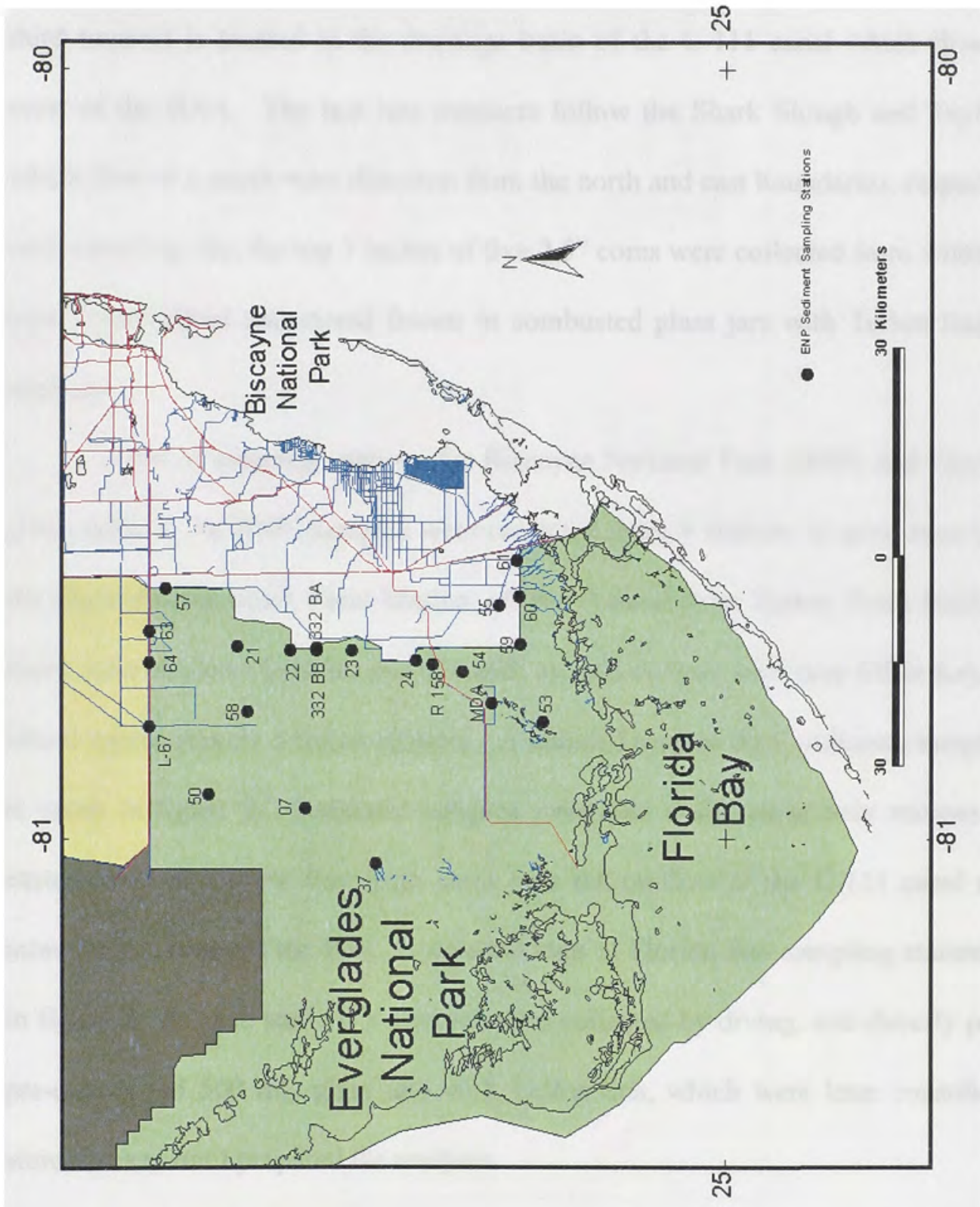

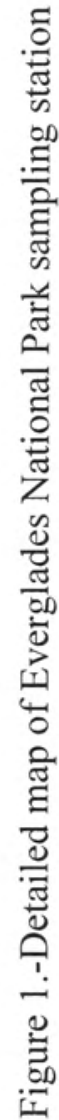


Areas to the north of the Park and lies just south of Tamiami Trail, the major highway in this area. The second transect follows a north-south direction across the eastern boundary of the park, this transect lies closest to the Homestead Agricultural Area (HAA). The third transect is located in the drainage basin of the C-111 canal which flows through most of the HAA. The last two transects follow the Shark Slough and Taylor Slough which flow in a south-west direction from the north and east boundaries, respectively. At each sampling site, the top 3 inches of five 2.5 " cores were collected from within a $100 \mathrm{~m}^{2}$ area, consolidated and stored frozen in combusted glass jars with Teflon lined lids for analysis.

A list of sampling stations for Biscayne National Park (BNP) and Florida Bay is given table 2. In BNP, samples were collected from 9 stations at areas near land along the channel from Black Point Marina, off the channel from Turkey Point Nuclear Power Plant, near outflows from an inland canal, as well as from sites near Elliot Key, a barrier island approximately 8 miles offshore. A detailed map of BNP sediment sample stations is given in figure 2. Sediment samples were also collected at four stations from the eastern area of Florida Bay from areas near the outflow of the C-111 canal as well as more remote areas of the Bay. A detailed map of Florida Bay sampling stations is given in figure 3. At each station, 3 samples were collected by diving, and directly placed into pre-combusted $500 \mathrm{~mL}$ glass jars with Teflon lids, which were later consolidated and stored frozen until prepared for analysis. 


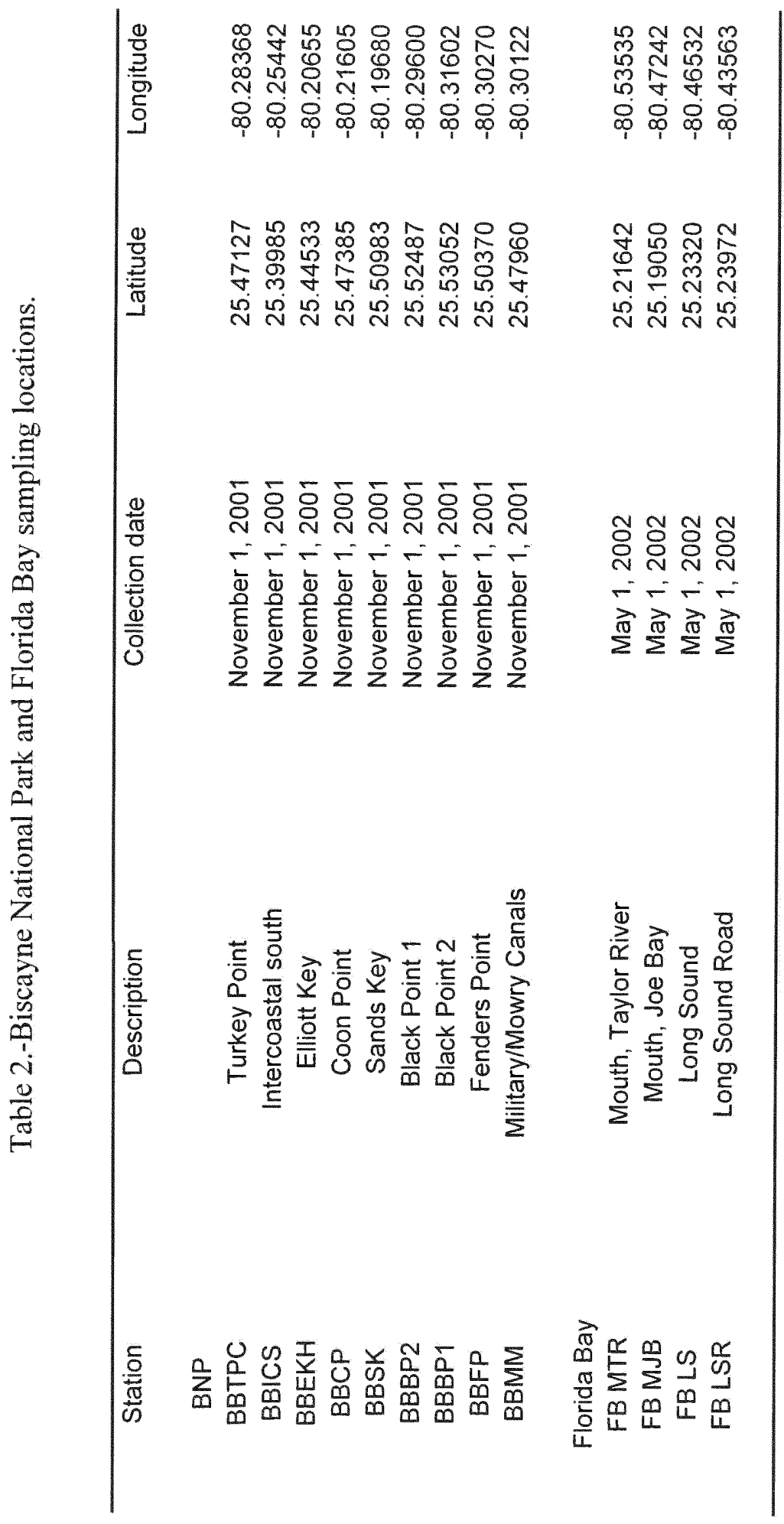




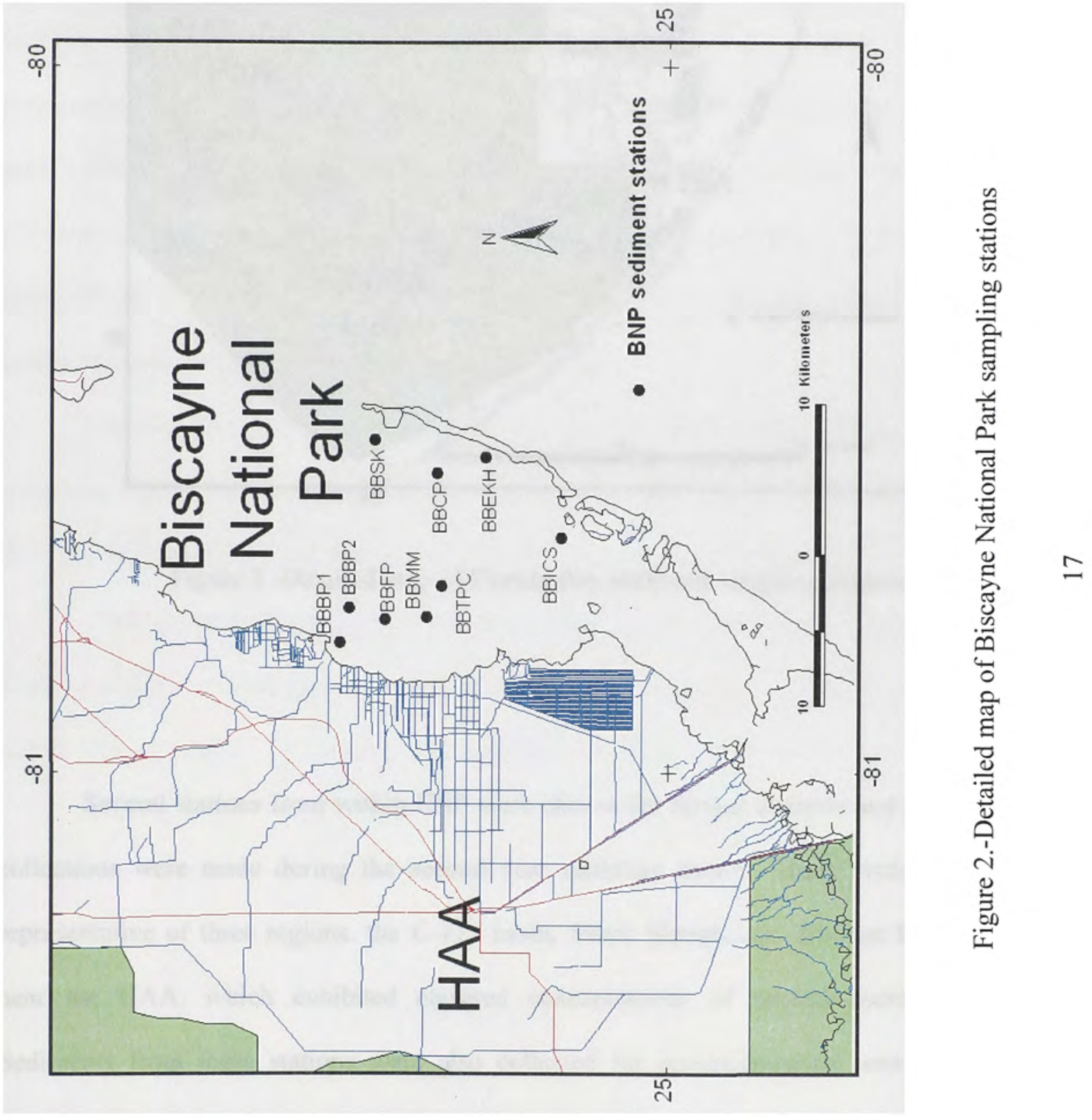




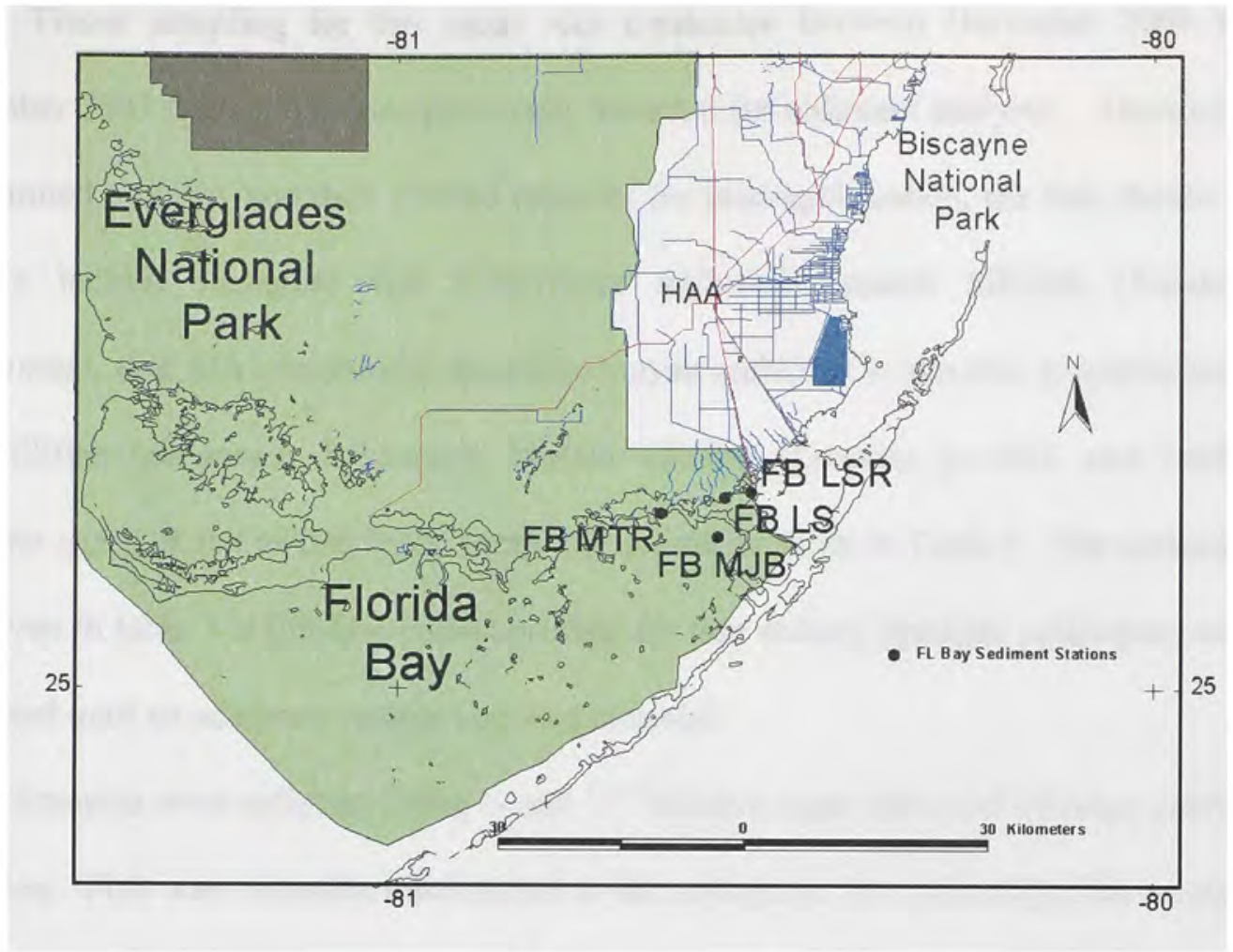

Figure 3.-Detailed map of Florida Bay sediment sampling stations.

Several stations from within ENP were chosen for further analysis and sediment collections were made during the second year sampling event. These stations were representative of three regions, the $\mathrm{C}-111$ basin, Shark Slough, and the East Boundary near the HAA, which exhibited elevated concentrations of several contaminants. Sediments from these stations were also collected for ecotoxicological assays to be conducted by FIU's ecotoxicology laboratory. 
Tissue sampling for this study was conducted between December 2001 and September 2003 from 14 stations previously sampled for sediment analysis. Because of their limited mobility and their limited capacity for biomagnification, the fish chosen for analysis include mosquito fish (Gambusia holbrooki, marsh killifish (Fundulus confluentus), flag fish (Jordanella floridae), mayan cichlid (Cichlasoma urophthalmus), pike killifish (Belanesox belizanus), bluefin killifish (Lucania goodie), and sunfish (Lepomis spp.). A list of fish tissue sampling stations is given in Table 3. The collection date given in table 3 is the first collection date for that station; multiple collections were conducted until an adequate sample size was attained.

Samples were collected using $1 / 4$ and $1 / 8$ " minnow traps deployed 24 hours prior to collection. Fish were identified and sorted at the collection sites and composite samples $(\mathrm{N}>20)$ were homogenized, then stored at $<-10^{\circ} \mathrm{C}$ until ready for analysis.

Fish samples were also collected from 6 stations in Florida Bay using cast nets. These samples included larger species of fish such as mojarra (Cichlasoma spp.) and mullet (Mugil spp.). A detailed map of fish sampling stations is given in figure 4 


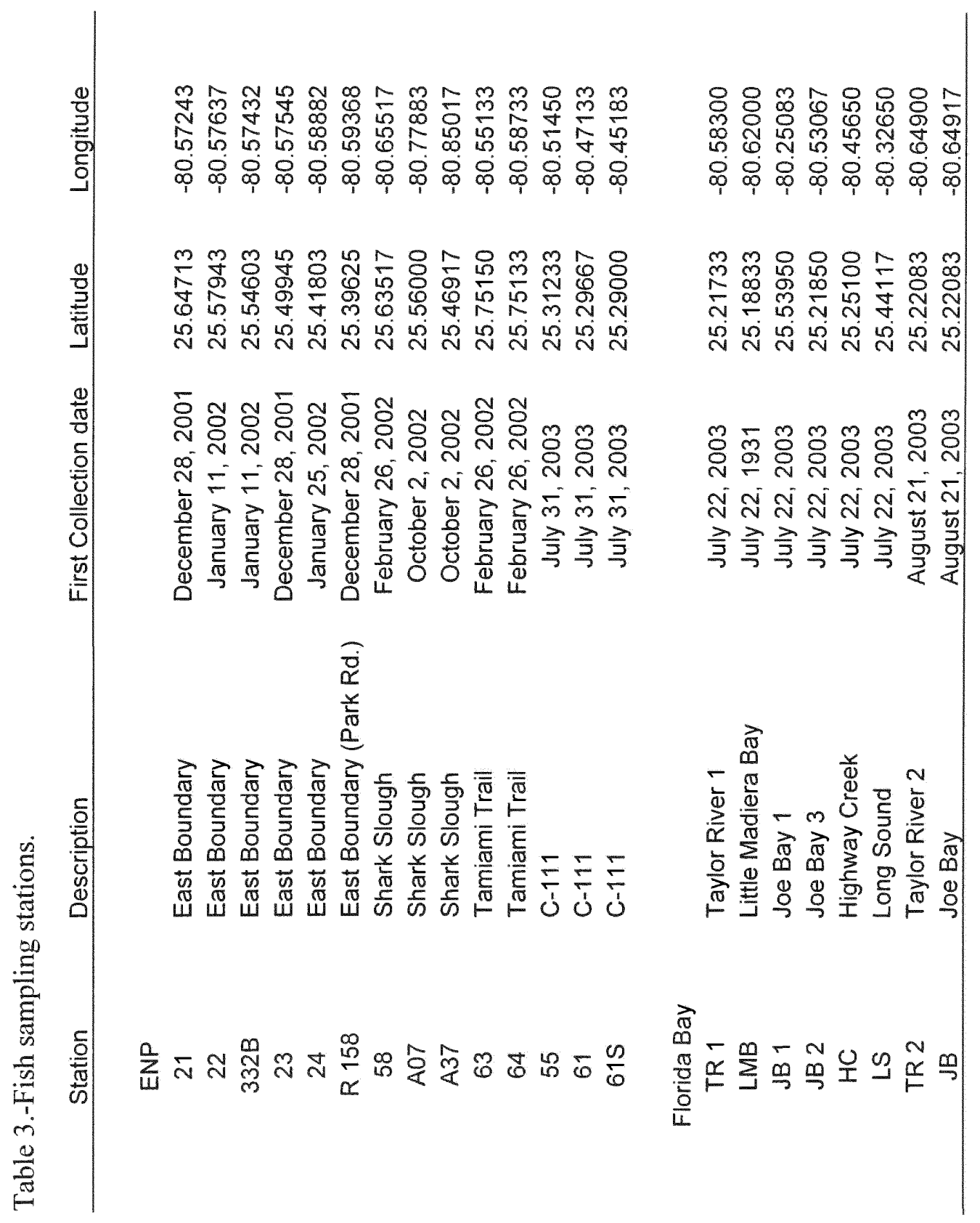




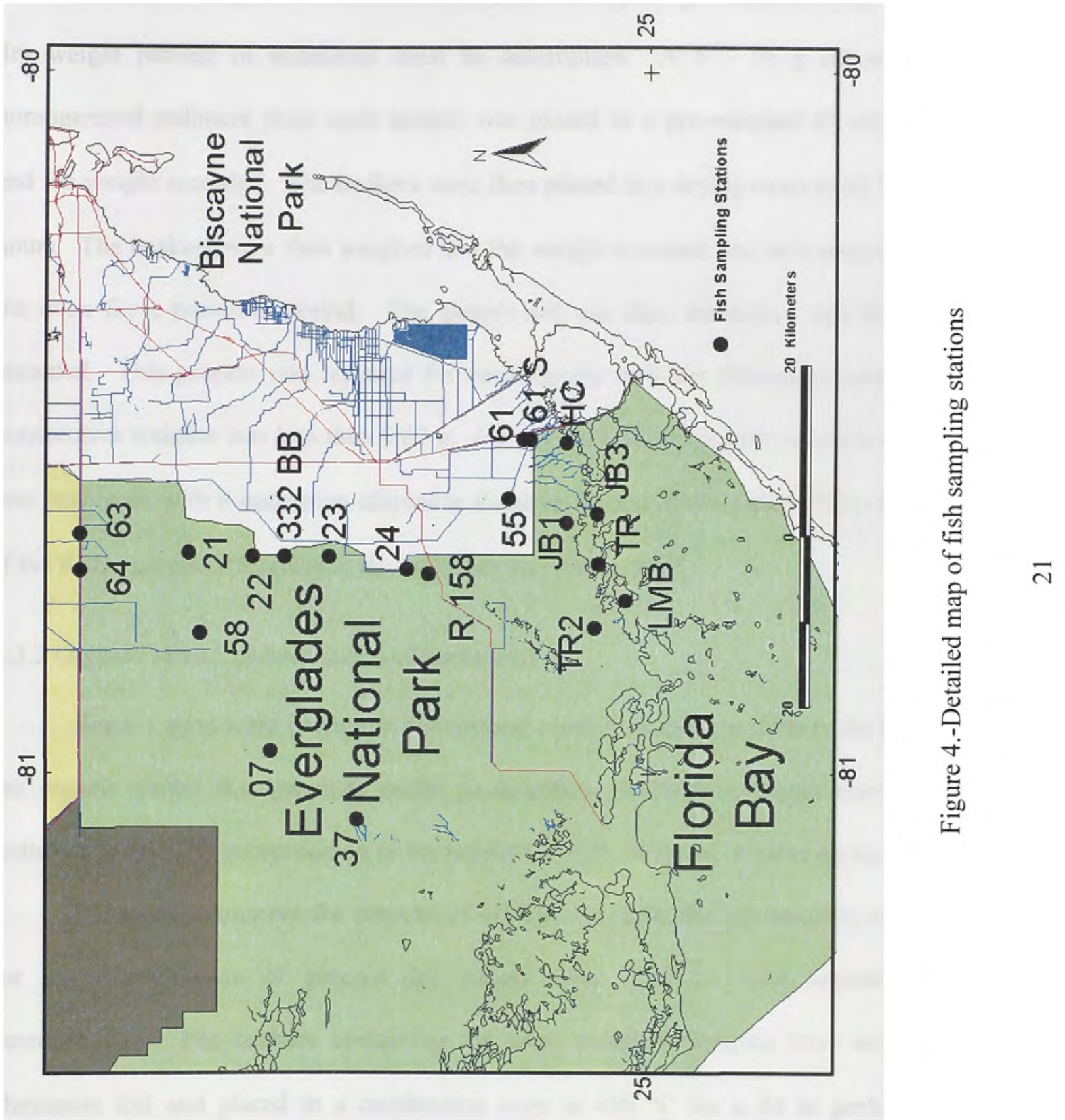




\subsection{Sample Preparation}

\subsubsection{Dry Weight Determination of Sediments}

In order to express the results of analysis on a dry weight basis for sediments, the dry weight percent of sediments must be determined. A $5-10 \mathrm{~g}$ sub-sample of homogenized sediment from each sample was placed in a pre-weighed $40 \mathrm{~mL}$ beakers and the weight recorded. The beakers were then placed in a drying oven at $65^{\circ} \mathrm{C}$ for 24 hours. The beakers were then weighed and the weight recorded and then placed back in the oven for a two-hour period. The sample set was then reweighed and the weight recorded. This process was repeated for each sample until the difference between two consecutive weights was less than $0.02 \mathrm{~g}$. For each set of 20 samples or less a duplicate was processed with a maximum allowable Relative Percent Difference (RSD) of $\pm 25 \%$. If the RSD exceeded the criteria, the entire set was reprocessed.

\subsubsection{Organic Matter Determination of Sediments}

Since a significant portion of the organic contaminants in sediments are bound to the organic matter fraction, it is useful to determine the organic matter content of a sediment sample for interpretation of the results of OCP, PCB, and PAH analysis.

In order to conserve the amount of available sample, the sub-samples employed for the determination of percent dry weight were used for total organic matter determination. The beakers containing the dried sediment samples were covered in aluminum foil and placed in a combustion oven at $450{ }^{\circ} \mathrm{C}$ for a $24 \mathrm{hr}$ period. The samples were then allowed to cool to room temperature in a dessicator. The beakers were then weighed and the weight recorded and then placed back in the oven for a two- 
hour period. The sample set was then reweighed and the weight recorded. This process was repeated for each sample until the difference between two consecutive weights was less than $0.02 \mathrm{~g}$. For each set of 20 samples or less a duplicate was processed with a maximum allowable Relative Percent Difference (RSD) of $\pm 25 \%$. If the RSD exceeded the criteria, the entire set was reprocessed.

\subsubsection{Sediment Grain Size Analysis}

Previous studies have shown that sediment contamination concentrations can be correlated to the grain particle size with higher concentrations associated with the smaller sized particles (Thompsom and Eglinton 1978). Therefore, this characterization was performed in this study.

A ROTAP RX-29 with 8" Fisher Brand test sieves was used to determine particle size distribution of sediment samples. The sieves used were: \# $10(2000 \mu \mathrm{m})$, \#60 (250 $\mu \mathrm{m})$, \# $120(125 \mu \mathrm{m})$, and \#230 $(63 \mu \mathrm{m}) .10-20 \mathrm{~g}$ sub-samples of homogenized sediment were dried in a drying oven at $65^{\circ} \mathrm{C}$ for at least $24 \mathrm{hrs}$. Samples were then placed over the \# 10 sieve, were covered and then sieved for 3 - 5 minutes. The top fraction $>2000 \mu \mathrm{m}$ was discarded, and the remaining four fractions were then each collected and weighed to $0.001 \mathrm{~g}$ to determine the percent of medium/ coarse/ $\mathrm{v}$. coarse sand, fine sand, very fine sand, and silt fractions. 


\subsubsection{Sediment preparation for ICP-MS determination of Metals}

The method used for digestion of sediment and soil samples for Inductively Coupled Plasma Mass Spectrometry (ICP-MS) is based on EPA Method 3052 for microwave assisted acid digestion of siliceous and organically based matrices. Between 0.2 and $0.5 \mathrm{~g}$ of thoroughly homogenized sediment (dry weight basis) was placed in a 100 $\mathrm{mL}$ fluorocarbon (PFA) microwave digestion vessel, and $10 \mathrm{~mL}$ of trace metal grade $\mathrm{HNO}_{3}$ was slowly added. The vessels were sealed and the samples were processed for a total of $15 \mathrm{~min}$. The samples were digested using a microwave digestion system (Mars 5, CEM) at $180^{\circ} \mathrm{C}$ for $9 \mathrm{~min}$ (EARL SOP-2000-I-001.1).

After digestion, the samples were quantitatively transferred to $100 \mathrm{ml}$ volumetric flasks and diluted to the mark with DDI water then transferred to acid cleaned $125 \mathrm{~mL}$ Nalgene HDPE bottles for storage prior to analysis. After the particulates settled, $2 \mathrm{ml}$ of the clear solution was placed in a $10 \mathrm{ml}$ plastic test tube and diluted to $10 \mathrm{ml}$ with DDI water. In the case of major elements such as aluminum, the solutions were diluted 100 times before ICP/MS analysis. Fifty microliters of internal standard solution (Y, Sc, In, and $\mathrm{Rh} 10 \mathrm{ppm}$ ) was added, thoroughly mixed, and the samples were ready for ICP/MS analysis. All samples were digested with a duplicate, and for each batch of 10 or less samples, blanks, matrix spikes, and reference materials were processed as part of the QA/QC protocol. Certified reference materials digested for soil/sediment analysis include PACS-2 marine sediment reference material obtained from National Research Council Canada (NRCC) and Buffalo River Sediment 2704 obtained from the National Institute of Standards and Technology (NIST). 
2.3.5 ish tissue preparation for GC-ECD determination of Organochlorine Pesticides, PCBs, and GC-MS determination of PAHs.

The method used for the extraction and clean-up of sediments for trace organic analysis is based on the method described by NOAA (1998). Approximately $20 \mathrm{~g}$ of the wet sediment samples were chemically dried using sodium sulfate $\left(\mathrm{Na}_{2} \mathrm{SO}_{4}\right)$; soxhlet extracted for 20 hours with $300 \mathrm{~mL}$ of dichloromethane in $500 \mathrm{~mL}$ flat bottom flasks. Samples were concentrated to $1 \mathrm{ml}$ hexane using a 3-ball Snyder column in a hot water bath at $65{ }^{\circ} \mathrm{C}$ followed by a quantitative transfer into a $25 \mathrm{~mL}$ concentrator tube with the addition of hexane until final volume was achieved and boiling ceased, solvent cleaned Teflon boiling chips were added at each concentration step. Samples were then purified from potential matrix interferences using a mixed bed silica-alumina chromatographic column.

The chromatographic column was prepared in Pentane with $10 \mathrm{~g}$ of Alumina previously deactivated with $1 \% \mathrm{wt} . / \mathrm{wt}$. DDI water followed by $20 \mathrm{~g}$ of Silica deactivated with $5 \%$ wt./wt. DDI water. $\mathrm{NaSO}_{4}$ was added on top to prevent humidity in the column. The sediment extract concentrated to $1 \mathrm{ml}$ of Hexane was added to the column. The first fraction containing the aliphatic hydrocarbons was eluted with $45 \mathrm{ml}$ of pentane at a rate of $1 \mathrm{~mL} / \mathrm{min}$. The second fraction was eluted with $250 \mathrm{ml}$ of a $1: 1$ mixture of pentane: dichloromethane. This second fraction contains the aromatic compounds that include PCBs, organochlorine pesticides and PAHs. Approximately $10 \mathrm{~g}$ of Acid activated (5\% $\mathrm{HCl})$ metallic copper $(\mathrm{Cu})$ was added to eliminate elemental Sulfur that can act as interference in the $\mathrm{GC} / \mathrm{ECD}$ determination of Organochlorine compounds. 
Internal standard surrogate solutions were added to each sample prior to extraction. For Organochlorine pesticide and PCB analysis, A $100 \mu \mathrm{L}$ solution of DBOFB (1.0355 ppm), PCB 103 (1.0385 ppm), PCB 198 (1.0135 ppm), and OCN (209.7 ppm) was added to each sample and QC sample. For PAH analysis a $100 \mu \mathrm{L}$ mixture of 2 ppm Napthalene-d8, Phenanthrene-d10, Chrysene-d12, Acenapthene-d10, and Perylene-d12, were added to each sample and QC sample. A $100 \mu \mathrm{L}$ spiking solution containing all Organochlorine analytes and a $100 \mu \mathrm{L}$ spiking solution containing all PAH analytes were added to each matrix spike (MS) and laboratory blank spike (LBS) for QA/QC prior to extraction.

Prior to transfer of the second fraction into $2 \mathrm{~mL}$ amber glass vials, $100 \mu \mathrm{L}$ of TCMX (1 ppm) and $100 \mu \mathrm{L}$ of 2 ppm Flourene-d10 and Benzo(a) Pyrene-d12 were added to each sample and QC sample as external standards for OC and PAH analysis respectively. For the aliphatic fraction, $100 \mu \mathrm{L}$ of TCMX $(1 \mathrm{ppm})$ was added as an external standard.

\subsubsection{Percent Dry Weight Determination of Tissue}

In order to express the results of analysis on a dry weight basis for tissue samples, the dry weight percent of the tissue must be determined. A $3-5$ g sub-sample of homogenized tissue from each sample was placed in a pre-weighed $40 \mathrm{~mL}$ beakers and the weight recorded. The beakers were then placed in Labconco vacuum freeze drier for 3 days. The beakers were then weighed and the weight recorded and then placed back in the freeze drier for a $24 \mathrm{hr}$. period. The sample set was then reweighed and the weight recorded. This process was repeated for each sample until the difference between two 
consecutive weights was less than $0.02 \mathrm{~g}$. For each set of 20 samples or less a duplicate was processed with a maximum allowable Relative Percent Difference (RSD) of $\pm 25 \%$. If the RSD exceeded the criteria, the entire set was reprocessed.

\subsubsection{Determination of Percent Lipid in Tissue}

Concentrations of organic contaminants are often expressed as a function of the percent lipid content of a tissue sample since most organic contaminants are lipophilic, and therefore tend to accumulate in higher concentrations where the percent lipid is greater. To method applied for determining the percent lipid content of tissue samples is modified from NOAA (1998), a $20 \mathrm{~mL}$ aliquot of the dichloromethane extracted tissue was placed in a loosely capped $24 \mathrm{~mL}$ vial and allowed to evaporate to dryness. The samples were then reconstituted to $1 \mathrm{~mL}$ in dichloromethane. $100 \mu \mathrm{L}$ was then transferred to a clean, dried, Whatman ${ }^{\circledR} \mathrm{GF} / \mathrm{C}$ glass microfibre filter paper $(1 \mathrm{~cm} \times 2$ $\mathrm{cm}$ ), pre-weighed to $0.001 \mathrm{mg}$ using a Cahn Electrobalance, and then placed on pleated sheet of heavy duty aluminum foil over a hot plate set at the lowest setting. After 30 minutes the filter paper was weighed and the weight recorded. This was repeated until the difference in weight between two consecutive weighs was less than $5 \%$. For each set of 20 or less samples, a duplicate sample was processed. If the RPD between duplicates was not within $\pm 25 \%$, the entire batch was reprocessed. 
Equation 1. Percent Lipids in fish tissue.

$$
\text { Percent Lipid }=\frac{T V}{A V} \times \frac{F V}{V W} \times \frac{L W}{S W} \times 100
$$

where TV is the total volume of the extract $(\mathrm{mL}), \mathrm{AV}$ is the volume of the aliquot $(\mathrm{mL})$, $\mathrm{FV}$ is the final volume $(\mathrm{mL}), \mathrm{VW}$ is the volume weighed $(\mathrm{mL}), \mathrm{LW}$ is the lipid weight $(\mathrm{g})$, and $\mathrm{SW}$ is the sample weight $(\mathrm{g})$.

2.3.8 Fish tissue preparation for GC-ECD determination of Organochlorine Pesticides, PCBs, and GC-MS determination of PAHs.

The method used in study for the extraction of fish tissue for trace organic analysis is modified from the method described by NOAA (1998) and has been applied previously for extraction of trace organics from tissues (Gardinali et al, 1996, Gardinali and Wade, 1998). An aliquot of $10-12 \mathrm{~g}$ (wet wt.) of tissue sample was weighed into a $200 \mathrm{~mL}$ centrifuge bottle and then the appropriate surrogate and spiking solutions were added. Approximately $40 \mathrm{~g}$ of anhydrous sodium sulfate and $100 \mathrm{~mL}$ of dichloromethane were then added to each bottle. Each sample was then macerated for 3 min using an Ultra Turrax ${ }^{\circledR}$ T18 Basic tissuemizer. The sample extract was then decanted and filtered through a funnel with a glass wool plug and approximately $40 \mathrm{~g}$ sodium sulfate pre-wetted with dichloromethane into a $500 \mathrm{~mL}$ flat bottom flask. The extraction was repeated two more times with $100 \mathrm{~mL}$ aliquots of dichloromethane, after the third extraction, the sample bottles were rinsed 3 times with dichloromethane and poured through the funnel into the flask. The total volume of the flask was then marked with a permanent marker and a $20 \mathrm{~mL}$ aliquot removed for lipid content analysis. 
Internal standard surrogate solutions were added to each sample prior to extraction. For Organochlorine pesticide and PCB analysis, A $100 \mu \mathrm{L}$ solution of DBOFB (1.0355 ppm), PCB 103 (1.0385 ppm), PCB 198 (1.0135 ppm), and OCN (209.7 ppm) was added to each sample and QC sample. For PAH analysis a $100 \mu \mathrm{L}$ mixture of 2 ppm Napthalene-d8, Phenanthrene-d10, Chrysene-d12, Acenapthene-d10, and Perylene-d12, were added to each sample and QC sample. A $100 \mu \mathrm{L}$ spiking solution containing all Organochlorine analytes and a $100 \mu \mathrm{L}$ spiking solution containing all PAH analytes were added to each matrix spike (MS) and laboratory blank spike (LBS) for QA/QC prior to extraction.

Prior to transfer of the second fraction into $2 \mathrm{~mL}$ amber glass vials, $100 \mu \mathrm{L}$ of $\operatorname{TCMX}(1 \mathrm{ppm})$ and $100 \mu \mathrm{L}$ of $2 \mathrm{ppm}$ Flourene-d10 and Benzo(a) Pyrene-d12 were added to each sample and QC sample as external standards for OC and PAH analysis respectively. For the aliphatic fraction, $100 \mu \mathrm{L}$ of TCMX (1 ppm) was added as an external standard.

The sample extract was then concentrated and purified using a mixed bed silicaalumina chromatographic column in manner similar to sediment samples as mentioned above except the addition of copper turnings, which are not necessary for tissue samples. After silica-alumina cleanup, sample extracts are concentrated to $1 \mathrm{~mL}$ of dichloromethane. 
2.3.9 Purification of Tissue samples by Gel Permeation Chromatography for Organic analysis

Sample extracts from biological tissue samples contain large amounts of lipids and high molecular weight components that may interfere with the instrumental analysis of PAHs, OCPs, and PCBs. Sample extracts are purified of these interferences by size exclusion chromatography using a gel permeation chromatographic technique employing a high performance liquid chromatography system consisting of an Acuflow Series I HPLC pump, and a Thermo Separation Products Spectra Series UV 150 ultraviolet detector set at $\lambda 254$. Samples were processed through a Phenomonex phenogel $50 \mathrm{x}$ $7.80 \mathrm{~mm} 10$ micron guard column and two Phenomonex phenogel $300 \times 21.20 \mathrm{~mm} 10$ micron $100 \mathrm{~A}$ columns.

Prior to introducing samples, the HPLC is calibrated using a solution containing spiking level concentration of all analytes and surrogates to be analyzed and an appropriate amount of fish oil to achieve a $10 \%$ lipid content in a dichloromethane solution. The calibration solution is introduced to the HPLC system at a rate of $5 \mathrm{~mL}$ per minute at an operating pressure of 350 to 450 psi. ELAB chromatographic software is used to determine the retention times of the lipid content and the target compounds to determine the appropriate collection times for each fraction. A dichloromethane blank is also processed to verify no contamination within the system. Total process time for each sample is $40 \mathrm{~min}$ with the desired fraction collected from about $21 \mathrm{~min}$ to $40 \mathrm{~min}$.

After calibration of the GPC-HPLC system was verified, alumina-silica purified samples pre-concentrated to just under $1 \mathrm{~mL}$ dichloromethane were introduced into the system and the desired fraction collected into $250 \mathrm{~mL}$ flat-bottomed flasks. A 
dichloromethane blank was processed after every five samples and a calibration solution processed after every ten samples. The GPC purified extract was then concentrated to approximately $5-10 \mathrm{~mL}$ in a hot water bath set a $65^{\circ} \mathrm{C}$ in the flat-bottomed flask with a 3-ball Snyder column. The concentrated sample was then quantitatively transferred into $25 \mathrm{~mL}$ concentrator tubes and concentrated to $1 \mathrm{~mL}$, exchanging the final solvent to hexane. The appropriate internal standards for GC-ECD and GC-MS analysis were then added before transferring samples into labeled $2 \mathrm{~mL}$ amber vials with Teflon lined caps for storage until ready for analysis.

2.3.9 Preparation of fish tissue samples for ICP-MS determination of trace elements.

The method employed for total digestion of tissue samples is an adaptation of EPA Method 3050B using an Environmental Express HotBlock ${ }^{\top \mathrm{M}}$. An aliquot of approximately 1 gram (wet wt.) was directly weighed into a $50 \mathrm{~mL}$ polypropylene digestion vessel. $10 \mathrm{~mL}$ of 50:50 trace metal grade (TMG) nitric acid and DDI water was then added to the vessel, swirled to mix well, covered with a watch glass and placed in the HotBlock at $95^{\circ} \mathrm{C}$ for 15 minutes. The sample was then removed from the HotBlock and allowed to cool before the addition of $5 \mathrm{~mL}$ of concentrated TMG nitric acid and then placed back in the HotBlock. After 60 minutes, the sample was removed from the HotBlock, allowed to cool before the addition of $2-5 \mathrm{~mL}$ of DDI water, followed by the slow addition of $1 \mathrm{~mL}$ of $30 \%$ A.C.S. certified $\mathrm{H}_{2} \mathrm{O}_{2}$, allowing $5-10$ minutes for exothermic reaction to occur before returning sample to the HotBlock. After 30 minutes an additional $0.5 \mathrm{~mL}$ of $\mathrm{H}_{2} \mathrm{O}_{2}$ is added to sample, this step is repeated until no reaction occurs upon addition of $\mathrm{H}_{2} \mathrm{O}_{2}$. After cooling, the sample is diluted to $50 \mathrm{~mL}$ in digestion 
vessel and is ready for analysis. QA/QC for each set of 20 or fewer samples included a blank, two blank spikes, and two matrix spikes were processed, whenever possible samples were processed in triplicates, if sufficient sample was not available for all samples, a duplicate was processed with each batch. A $0.25-0.5 \mathrm{~g}$ aliquot of DORM-2 (CNRC) dogfish muscle reference material was digested with each batch as part of the QA/QC protocol.

\subsection{Instrumental Analysis}

\subsubsection{Organochlorine Pesticide and PCB determination by GC-ECD}

Chlorinated hydrocarbons can be determined at trace concentrations (ppb) using gas chromatography with and electron capture detector (ECD), a list of target analytes if given in Table 4. Purified extracts were analyzed for chlorinated hydrocarbons in a Hewlett Packard 5980II gas chromatography with electron capture detection (GC-ECD) using a 30 -meter, $0.25 \mathrm{~mm}$ i.d., $25 \mu \mathrm{m}$ DB-5 fused silica capillary column from $\mathrm{J} \& \mathrm{~W}$ Scientific. The HP 5880II GC is equipped with a split/splitless capillary inlet system with a splitless liner, ultra high purity (UHP) grade helium as a carrier gas (25 psi), and UHP grade nitrogen for make-up gas ( $40 \mathrm{psi})$. The initial temperature for the oven is $100^{\circ} \mathrm{C}$, and it reaches a maximum temperature of $300^{\circ} \mathrm{C}$. The injection port has a temperature of $280^{\circ} \mathrm{C}$ and the $\mathrm{ECD}$ at $325^{\circ} \mathrm{C}$. The run length is about $93.33 \mathrm{~min}$. 
Table 4.-Organochlorine pesticides and Polychlorinated Biphenyls of interest.

\begin{tabular}{|c|c|}
\hline Pesticides & Polychlorinated biphenyls \\
\hline Chlrorinated Benzenes & Dichlorobiphenyls \\
\hline Tetrachlorobenzene $1,2,4,5$ & $\mathrm{PCB} 8 / 5$ \\
\hline Tetrachlorobenzene $1,2,3,4$ & Trichlorobiphenyls \\
\hline Pentachlorobenzene & PCB18/17 \\
\hline Hexachlorobenzene & PCB29 \\
\hline Hexachlorocyclohexanes & $\mathrm{PCB} 28 / 31$ \\
\hline Alpha $\mathrm{HCH}$ & Tetrachlorobiphenyls \\
\hline Beta $\mathrm{HCH}$ & PCB52 \\
\hline Gamma HCH & PCB44 \\
\hline Delta $\mathrm{HCH}$ & PCB66/95 \\
\hline Chlorodane-related Compounds & Pentachlorobiphenyls \\
\hline Heptachlor & PCB101/90 \\
\hline Heptachlor Epoxide/OCS & PCB87/115 \\
\hline Alpha Chlordane & PCB105 \\
\hline Gamma Chlordane & Hexachlorobiphenyls \\
\hline Other Cyclodiene Pesticides & PCB153/132 \\
\hline Aldrin & PCB138 /160 \\
\hline Dieldrin & Heptachlorobiphenyls \\
\hline Endrin & PCB187 \\
\hline Other Chlorinated Pesticides & PCB180 \\
\hline Chlorpyrifos & PCB170/190 \\
\hline Mirex & Octochlorobiphenyls \\
\hline Endosulfan Sulfate & PCB195/208 \\
\hline Endosulfan II & Nonachlorobiphenyls \\
\hline DDTs and Related Compounds & PCB206 \\
\hline 2,4' DDE/ENDOSULFAN I & Decachlorobiphenyls \\
\hline $4,4^{\prime} \mathrm{DDE}$ & PCB209 \\
\hline \multicolumn{2}{|l|}{$2,4^{\prime} \mathrm{DDD}$} \\
\hline \multicolumn{2}{|l|}{$4,4^{\prime} \mathrm{DDD}$} \\
\hline \multicolumn{2}{|l|}{ 2,4' DDT } \\
\hline 4,4' DDT & \\
\hline
\end{tabular}


Internal standard quantitation with a 5 -point calibration curve $(5-200 \mathrm{ng} / \mathrm{mL})$ was used for the analytical determinations. The analysis requires a correlation coefficient of 0.99 for all of the compounds analyzed. Analyte concentrations were calculated based on surrogate standards using PCB 103. Surrogate standard recoveries were calculated using the internal standard TCMX. For each set of samples analyzed, all QA samples including blanks, fortified laboratory blanks, duplicates, and matrix spikes were included in the sequence. The calibration standards were interspersed throughout the sequence to account for instrument drift of retention times and changes in sensitivity.

In the event the response for any sample peak exceeded the highest calibration solution, the extract was diluted and a known amount of surrogate solution added. The final concentration was then reported, adjusted for dilution using the ratio between TCMX and the added surrogate concentrations.

\subsubsection{PAHs determination by GC-MS}

GC-MS provides sensitive detection of polycyclic aromatic hydrocarbons (PAHs) at low concentrations due to their strong molecular ion response. A list of PAHs analyzed is given in Table 5. PAHs were analyzed from the purified extracts using a Hewlett-Packard HP5890II-HP5971 gas chromatography-mass spectrometry system operated in selected ion mode (GC/MS-SIM). Chromatographic separation was achieved in a 30-meter $0.25 \mathrm{~mm}$ i.d., $25 \mu \mathrm{m}$ DB5-MS fused silica capillary column using UHP grade helium as the carrier gas at a flow of $2.0 \mathrm{~mL} / \mathrm{min}$. The mass spectrometer was operated at $70 \mathrm{eV}$ electron energy in the electron impact ionization mode. The injection port was held at $300^{\circ} \mathrm{C}$ and operated in splitless mode. The oven was set up at an initial 
Table 5.-Polycyclic Aromatic Hydrocarbons of interest.

\begin{tabular}{|c|c|c|}
\hline GC Standards & Quantitation ion & Confirmation ion \\
\hline Benzo(a)pyrene $d-12$ & 264 & 260 \\
\hline Fluorene-d10 & 176 & 174 \\
\hline \multicolumn{3}{|l|}{ Surrogates } \\
\hline Perylene-d12 & 264 & 260 \\
\hline Naphthalene-d8 & 136 & 134 \\
\hline Acenaphthene-d10 & 164 & 162 \\
\hline Phenanthrene-d10 & 188 & 184 \\
\hline Chrysene-d12 & 240 & 236 \\
\hline \multicolumn{3}{|l|}{ Target Compounds } \\
\hline Naphthalene & 128 & 127 \\
\hline 2-methylnapthalene & 142 & 141 \\
\hline 1-methylnapthalene & 142 & 141 \\
\hline 2,6-dimethylnapthalene & 156 & 141 \\
\hline 1,6,7-trimethylnapthalene & 170 & 155 \\
\hline C2-Napthalenes & 156 & 141 \\
\hline C3-Napthalenes & 170 & 155 \\
\hline C4-Napthalenes & 184 & 169 \\
\hline Biphenyl & 154 & 153 \\
\hline Acenaphthylene & 152 & 153 \\
\hline Acenaphthene & 154 & 153 \\
\hline Flourene & 166 & 165 \\
\hline C1-fluorene & 180 & 165 \\
\hline C2mfluorene & 194 & 179 \\
\hline C3-fluorene & 208 & 193 \\
\hline Dibenzothiophene & 184 & 152 \\
\hline C1-Dibenzothiophenes & 198 & 184 \\
\hline C2-Dibenzothiophenes & 212 & 197 \\
\hline C3-Dibenzothiophenes & 226 & 211 \\
\hline Phenanthrene & 178 & 176 \\
\hline Anthracene & 178 & 176 \\
\hline Carbazole & 167 & 166 \\
\hline 1-methylphenanthrene & 192 & 191 \\
\hline C1-phenan/anthrac & 192 & 191 \\
\hline C2-phenan/anthrac & 206 & 191 \\
\hline C3-phenan/anthrac & 220 & 205 \\
\hline C4-phenan/anthrac & 234 & 219 \\
\hline
\end{tabular}


Table 5 continued.-Polycyclic Aromatic Hydrocarbons of interest.

\begin{tabular}{lll}
\hline Flouranthene & 202 & 101 \\
Pyrene & 202 & 10 \\
C1-fluor/pyrene & 216 & 21 \\
Benz(a)anthracene & 228 & 22 \\
Chrysene & 228 & 22 \\
C1-chrysenes & 242 & 14 \\
C2-chrysenes & 256 & 241 \\
C3-chrysenes & 270 & 25 \\
C4-chrysenes & 284 & $\mathrm{~N} A$ \\
Benzo(b)flouranthene & 252 & 253 \\
Benzo (k)fluoranthene & 252 & 25 \\
Benzo (e)pyrene & 252 & 253 \\
Benzo (a)pyrene & 252 & 253 \\
Indeno[1,2,3-cd]pyrene & 276 & 277 \\
Benzo[g,h,i,jperylene & 276 & 277 \\
Dibenzo(ah)anthracene & 278 & 27 \\
Perylene & 252 & 25 \\
\hline
\end{tabular}

temperature of $55^{\circ} \mathrm{C}$ and a final temperature of $300^{\circ} \mathrm{C}$ at a rate of $6.5^{\circ} \mathrm{C} / \mathrm{min}$. The total run time was $50 \mathrm{~min}$.

A 5-point calibration curve $(20 \mathrm{ng} / \mathrm{mL}-4000 \mathrm{ng} / \mathrm{mL})$ with a correlation coefficient of $>0.99$ for all analytes was used to demonstrate the linear range of the detector. Analyte concentrations are calculated based on surrogate standards Napthalened8, Phenanthrene-d10, Chrysene-d12, Acenapthene-d10, and Perylene-d12. Surrogate standard recoveries are calculated based on internal standards benzo(a)pyrene-d12 and flourene-d10. A NIST standard reference material (SRM 1491) at a concentration of $12000 \mu \mathrm{L} / \mathrm{mL}$ with appropriate surrogates and internal standards is processed with every sequence to verify accuracy of calibration curve. For each set of samples analyzed, all QA samples including blanks, fortified laboratory blanks, duplicates, and matrix spikes were included in the sequence. 
2.4.3 Trace and Major Element Determination by ICP-MS

The method used for inductively coupled plasma-mass spectroscopy (ICP-MS) determination of trace and major elements was developed based on EPA Method 6020A (Revision 1, 1998). This method was chosen for its ability to analyze for a wide range of elements at the ppb level in a very short amount of time. The elements chosen for determination in this study and their masses of interest are listed in Table 6.

Table 6.-Trace and major elements of interest (EPA Method 6020A).

\begin{tabular}{lcc}
\hline Element & Masses & IS \\
Aluminum (Al) & 27 & 45 \\
Arsenic (As) & 75 & 89,103 \\
Beryllium (Be) & 9 & 45 \\
Cadmium (Cd) & $111,112,114$ & 103,115 \\
Chromium (Cr) & 52,53 & 45,89 \\
Cobalt (Co) & 59 & 45,89 \\
Copper (Cu) & 63,65 & 45,89 \\
Lead (Pb) & $206,207,208$ & 89,103 \\
Nickel (Ni) & $58,60,61$ & 89,103 \\
Silver (Ag) & 107,109 & 89,103 \\
Vanadium (V) & 51 & 45,89 \\
Zinc ( $\mathrm{Zn})$ & $64,66,68$ & 45,89 \\
\hline
\end{tabular}




\subsubsection{ICP-MS determination of sediment samples}

The ICP-MS instrument used for metal analysis of sediments was Model HP 4500 plus (Hewlett-Packard Co., Wilmington, DE) equipped with a Babington-type nebulizer and an ASX-500 autosampler (Cetac Technologies Inc., Omaha, NE). Instrument configuration and general experimental conditions were reported previously (EARL SOP-2000-I-004.1). A set of 9 calibration points was used for minor and major elements $(0,2,5,7,10,20,50,100,200 \mathrm{ppb})$. The analysis requires a coefficient of correlation greater than 0.99 for all elements. For each sample, $2 \mathrm{~mL}$ of digestate $\left(10 \% \mathrm{HNO}_{2}\right)$ was placed in a $15 \mathrm{~mL}$ plastic test tube, then $50 \mu \mathrm{L}$ of $10 \mathrm{ppm}$ internal standard solution (Y, In, $\mathrm{Sc}$, and $\mathrm{Rh})$ was added to each test tube, and the solution diluted to $10 \mathrm{~mL}(2 \%$ $\mathrm{HNO}_{2}$ ). Internal standards were added to all samples, calibration standards, instrument checks, and QA samples to correct for instrument drift and physical interferences present in sample matrices. For analysis of aluminum, samples were diluted 100 times to bring the concentrations within the calibration curve.

The QA/QC protocol for each batch of samples processed includes blanks, blank spikes, matrix spikes, duplicates, and SRM. An instrument check solution, obtained from a source independent of the calibration and stock standards, containing all analytes of interest was processed at 3 concentration levels at the beginning, middle, and end of each sequence to verify accuracy of calibration curve and check for instrument drift.

2.4.3.2 ICP-MS determination of tissue samples

The ICP-MS instrument used for metal analysis of tissue samples was a Perkin Elmer ELAN DRC equipped with a Babington-type nebulizer and an ASX-500 autosampler (Cetac Technologies Inc., Omaha, NE). A 15-point calibration curve $(0$, 
$0.02,0.05,0.1,0.2,0.5,1.0,2.0,5,7,10,20,50,100,200 \mathrm{ppb})$ was used for all elements. The analysis requires a coefficient of correlation greater than 0.99 for all elements.

For each sample, $1 \mathrm{~mL}$ of digestate $\left(20 \% \mathrm{HNO}_{2}\right)$ was placed in a $15 \mathrm{~mL}$ plastic test tube, then $50 \mu \mathrm{L}$ of $10 \mathrm{ppm}$ internal standard solution (Y, In, Sc, and $\mathrm{Rh}$ ) was added to each test tube, and the solution diluted to $10 \mathrm{~mL}\left(2 \% \mathrm{HNO}_{2}\right)$. Internal standards were added to all samples, calibration standards, instrument checks, and QA samples to correct for instrument drift and physical interferences present in sample matrices. QA/QC protocol for tissue analysis was the same as that for sediment analysis. 


\section{RESULTS AND DISCUSSION}

\subsection{Sediment Contamination Assessment}

To date, there are no state or federal standards or mandates concerning contamination of sediments and soils. However, several environmental regulatory agencies, such as the National Oceanic and Atmospheric Administration (NOAA), the U.S. Environmental Protection Agency (EPA), and the Florida Department of Environmental Protection (FDEP) have developed guidelines to be used in assessing the potential hazard of certain pollutants in both freshwater and marine environments as well as in sediments and soils.

FDEP has established Sediment Quality Assessment Guidelines (SQAGs) in order to evaluate the potential for biological effects associated with sediment-sorbed contaminants (MacDonald, 1994). The SQAGs developed for Florida are based on high quality sediment toxicity databases. These databases were used to develop two guidelines for interpreting the effects of contaminants on biological endpoints; these are a threshold effects level (TEL) and a probable effects level (PEL). The TEL represents the upper range limit of contamination for which no effects are observed in the majority of toxicity studies done for that contaminant. Below this level, contaminants are not considered to pose a significant hazard to aquatic organisms. The PEL represents the lower limit of a contaminants concentration, which is usually associated with adverse biological effects to aquatic organisms. Above this level, contaminant concentrations could potentially be associated with adverse biological effects. These guidelines even though applicable to freshwater environments, were developed for marine environments. 
Thus, whenever available, TEL and PEL criteria for freshwater sediments as described by NOAA Screening Quick Reference Tables (SQRTs) are used.

3.2 Organic Contaminants in Sediments

\subsubsection{Organochlorine Pesticides}

A total of 25 organochlorine pesticide (OCP) compounds were chosen for this analysis. A summary of the OCP compounds detected in the sediments and their concentration ranges are given in Table 7. Of the OCPs detected in sediments from Everglades National Park, only DDT, its metabolites DDD and DDE, and dieldrin were in exceedance of the established TEL criteria. PEL criteria were not exceeded for any contaminant at any of the stations. Ranked concentrations of these contaminants vs. TEL/PEL criteria are shown in figures 5-8. Since organic contaminants tend to accumulate more in sediments with greater organic matter (OM) content, OCP concentrations are also plotted normalized against total OM to account for variations in OM within the study area. It should be noted that concentrations expressed in ng/g organic carbon, are not applicable to the TEL and PEL criteria that are expressed in $\mathrm{ng} / \mathrm{g}$ dry weight. Several other pesticides were also detected frequently, at very low levels, in sediment samples throughout ENP. For example, aldrin, endrin, and chlorpyrifos, were detected in $59 \%(13 / 22), 46 \%(10 / 22)$, and $9 \%(2 / 22)$ of the samples respectively. However, these concentrations are low $(<1.0 \mathrm{ppb})$ and should not be of particular concern. The spatial distributions of total DDTs and p-p DDE in ENP, BNP and Florida Bay sediments are given in figures 9-10. 


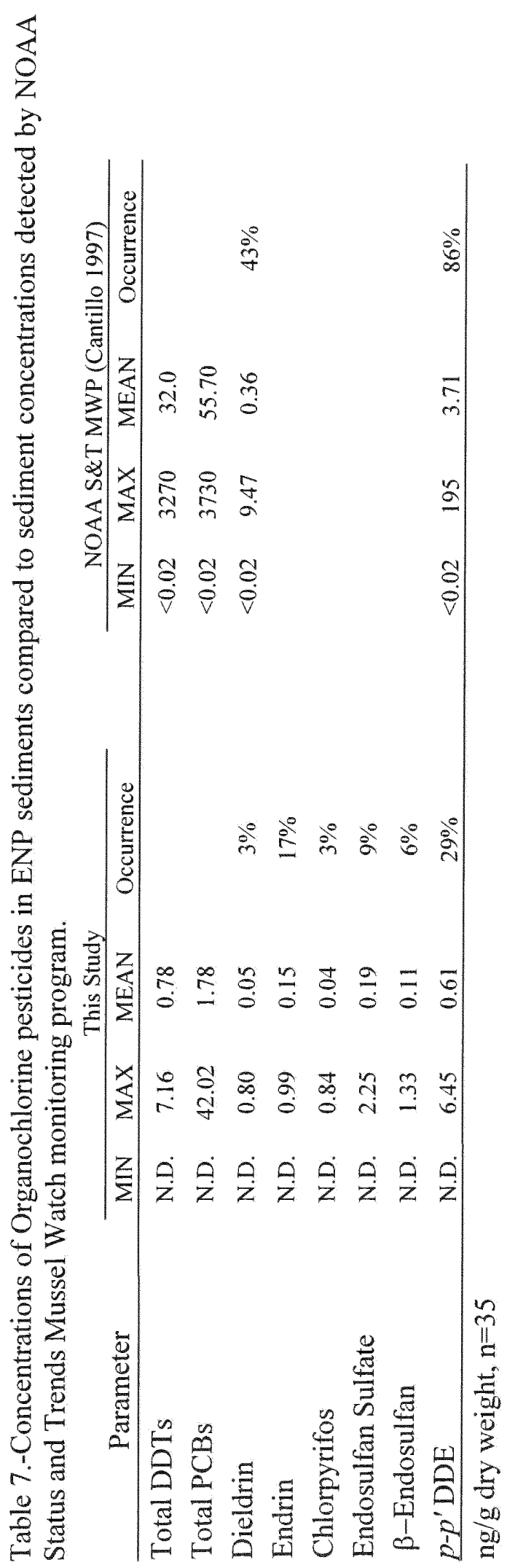




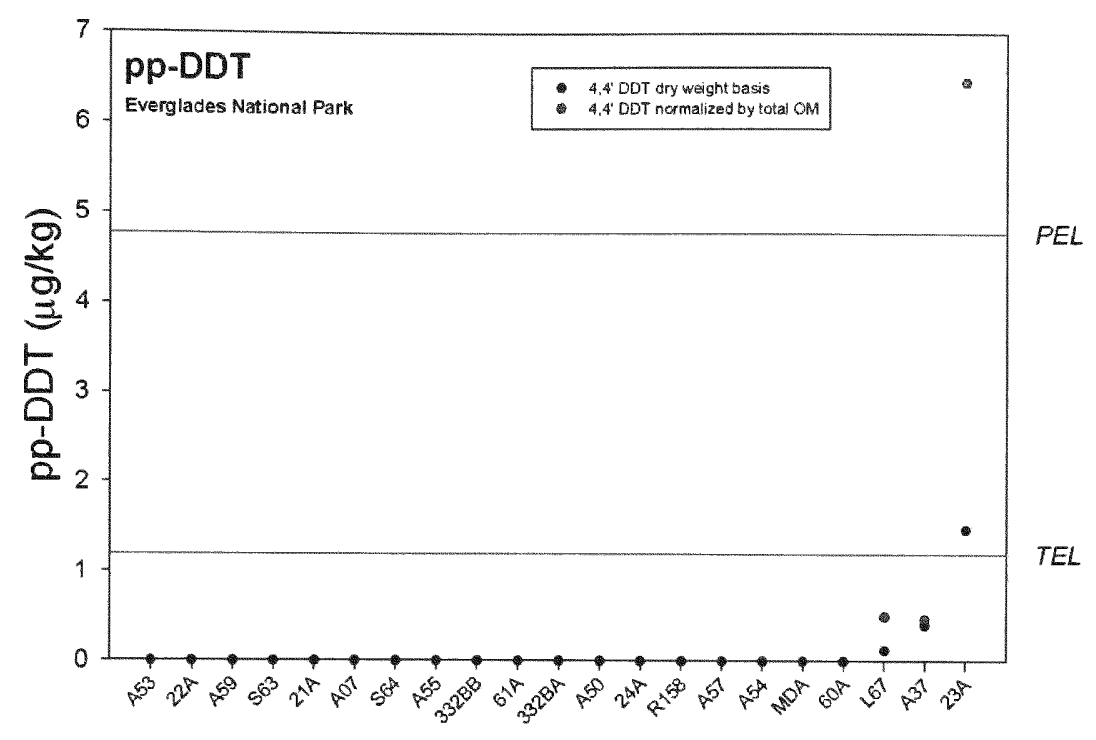

Station

Figure 5.- Ranked concentrations of p-p'DDT in ENP sediment.

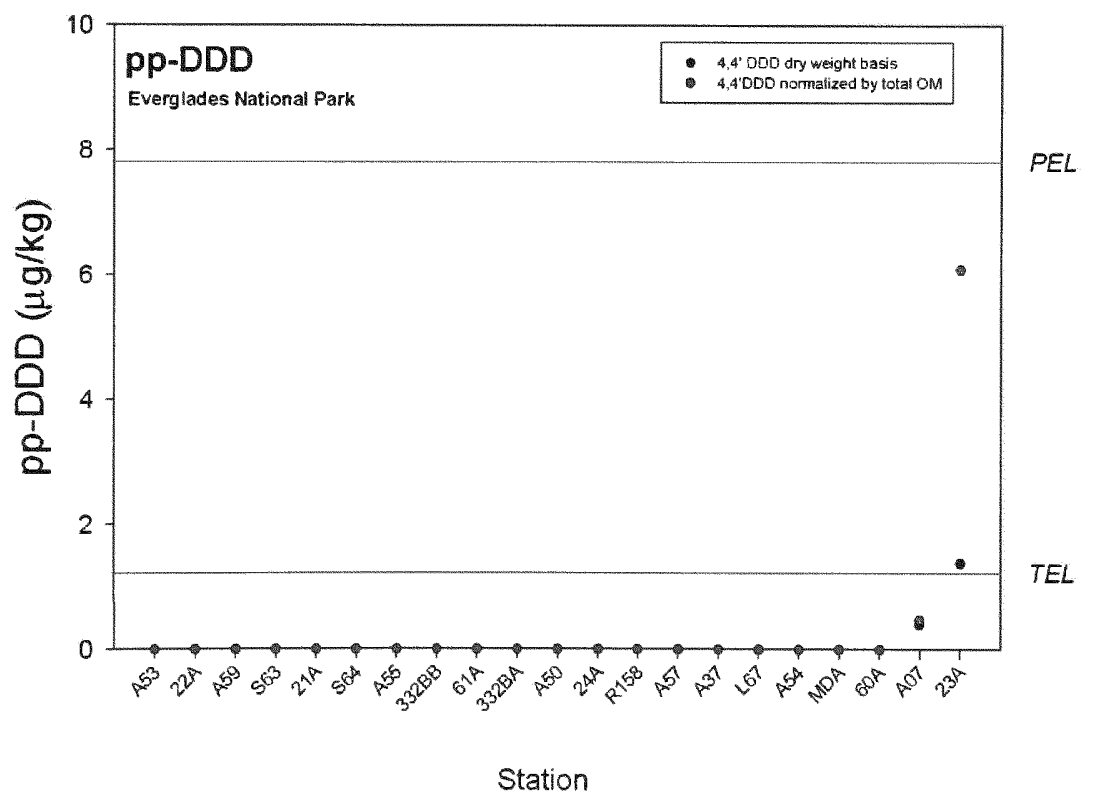

Figure 6.- Ranked concentrations of p-p'DDD in ENP sediment. 


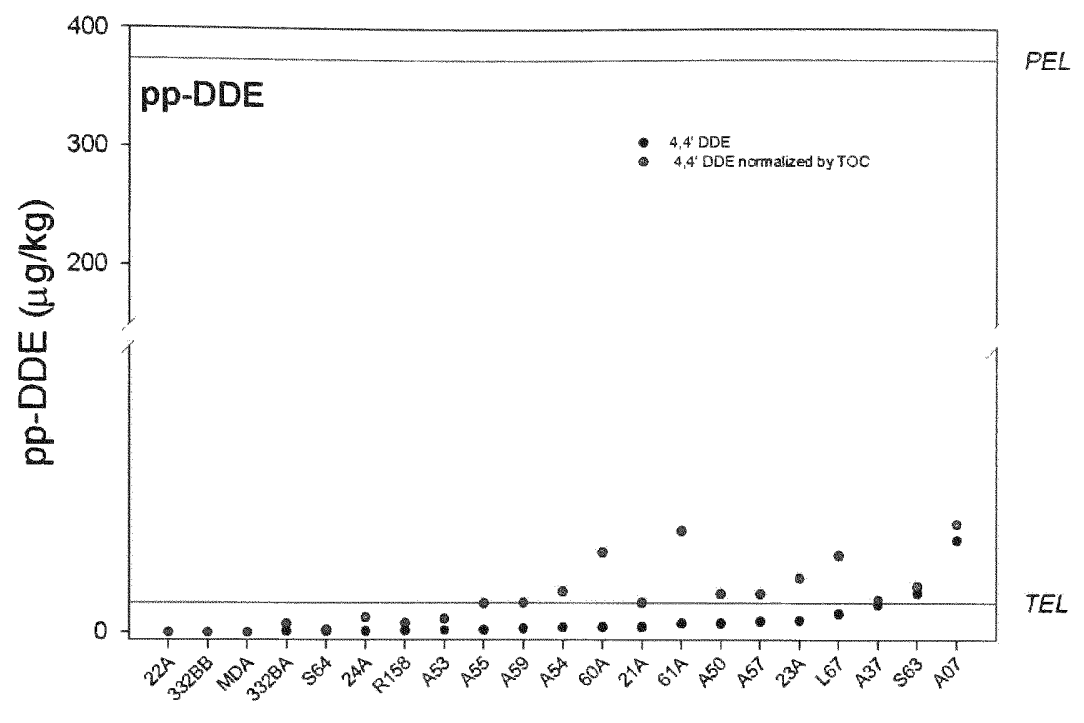

Station

Figure 7.-Ranked concentrations of p-p'DDE in ENP sediment.

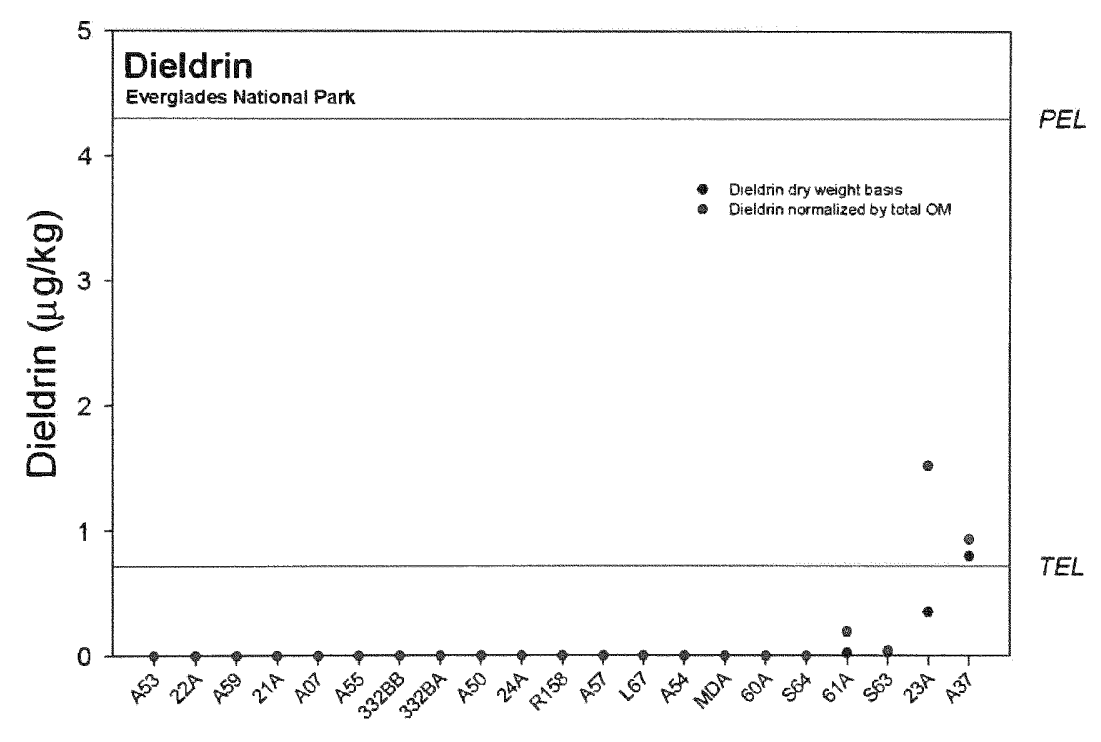

Station

Figure 8.-Ranked concentrations of Dieldrin in ENP sediment. 


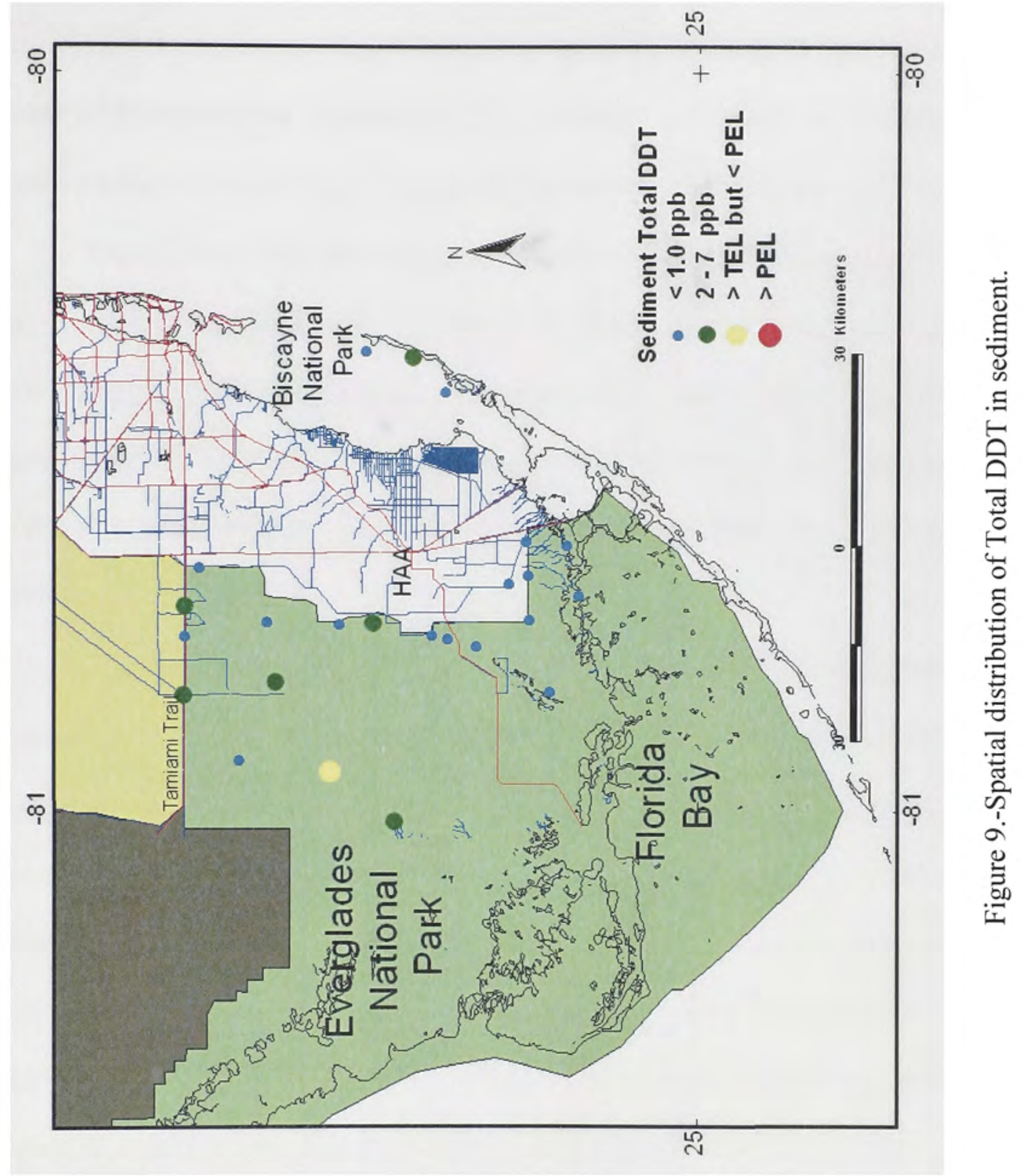




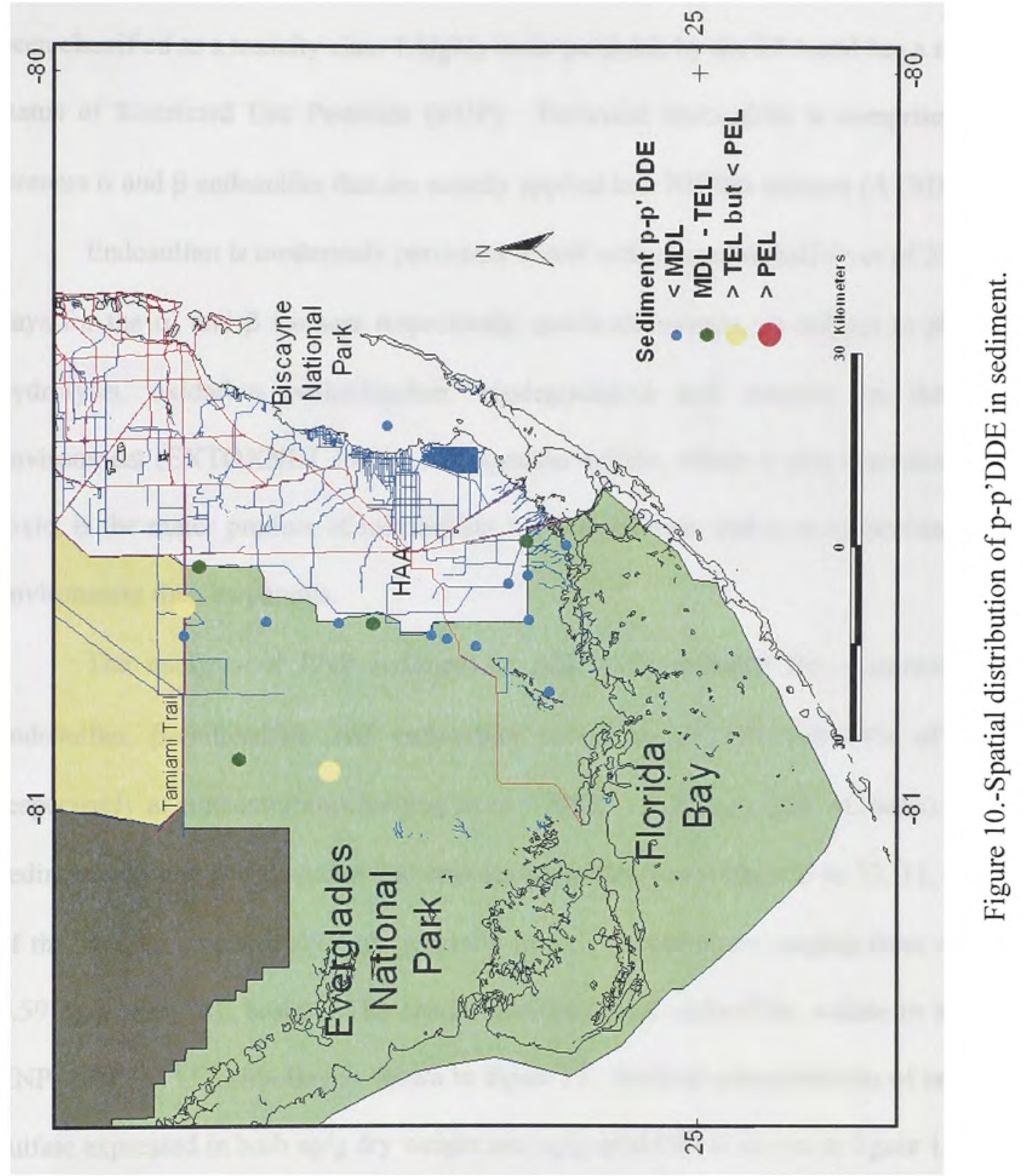


One compound of particular concern in south Florida because of its extensive use in the HAA is endosulfan. More than $70 \%$ of the endosulfan applied in the southeastern U.S. is applied to vegetable crops in south Florida (Scott et. al. 2002). Endosulfan has been classified as a toxicity class 1 highly toxic pesticide by the EPA and has a regulatory status of Restricted Use Pesticide (RUP). Technical endosulfan is comprised of two isomers $\alpha$ and $\beta$ endosulfan that are usually applied in a 70/30\% mixture (ATSDR 2002).

Endosulfan is moderately persistent in soil with estimated half-lives of 35 and 150 days for the $\alpha$, and $\beta$ isomers respectively, and both isomers are subject to photolysis, hydrolysis, oxidation, volatilization, biodegradation and sorption in the aquatic environment (EXTOXNET 1996). Endosulfan sulfate, which is also considered highly toxic, is the major product of metabolism for both isomers and is more persistent in the environment than its parents.

The analysis of ENP sediment in this study revealed the occurrence of $\alpha$ endosulfan, $\beta$-endosulfan, and endosulfan sulfate in 27,50 , and $64 \%$ of samples respectively at concentrations ranging from $<\mathrm{MDL}-2.25 \mathrm{ng} / \mathrm{g}$ (dry wt. basis). In BNP sediments, $\alpha$ and $\beta$ endosulfan and endosulfan sulfate were detected in 33,11 , and $22 \%$ of the samples respectively with generally lower concentrations ranging from $<\mathrm{MDL}-$ $0.59 \mathrm{ng} / \mathrm{g}$ (dry wt. basis). The spatial distribution of endosulfan sulfate in sediments ENP, BNP, and Florida Bay is shown in figure 11. Ranked concentrations of endosulfan sulfate expressed in both $\mathrm{ng} / \mathrm{g}$ dry weight and $\mathrm{ng} / \mathrm{g}$ total $\mathrm{OM}$ is shown in figure 12 .

Insufficient data were available for development of SQAGs for both $\alpha$ and $\beta$ endosulfan or their primary metabolite endosulfan sulfate (MacDonald 1994). However, 


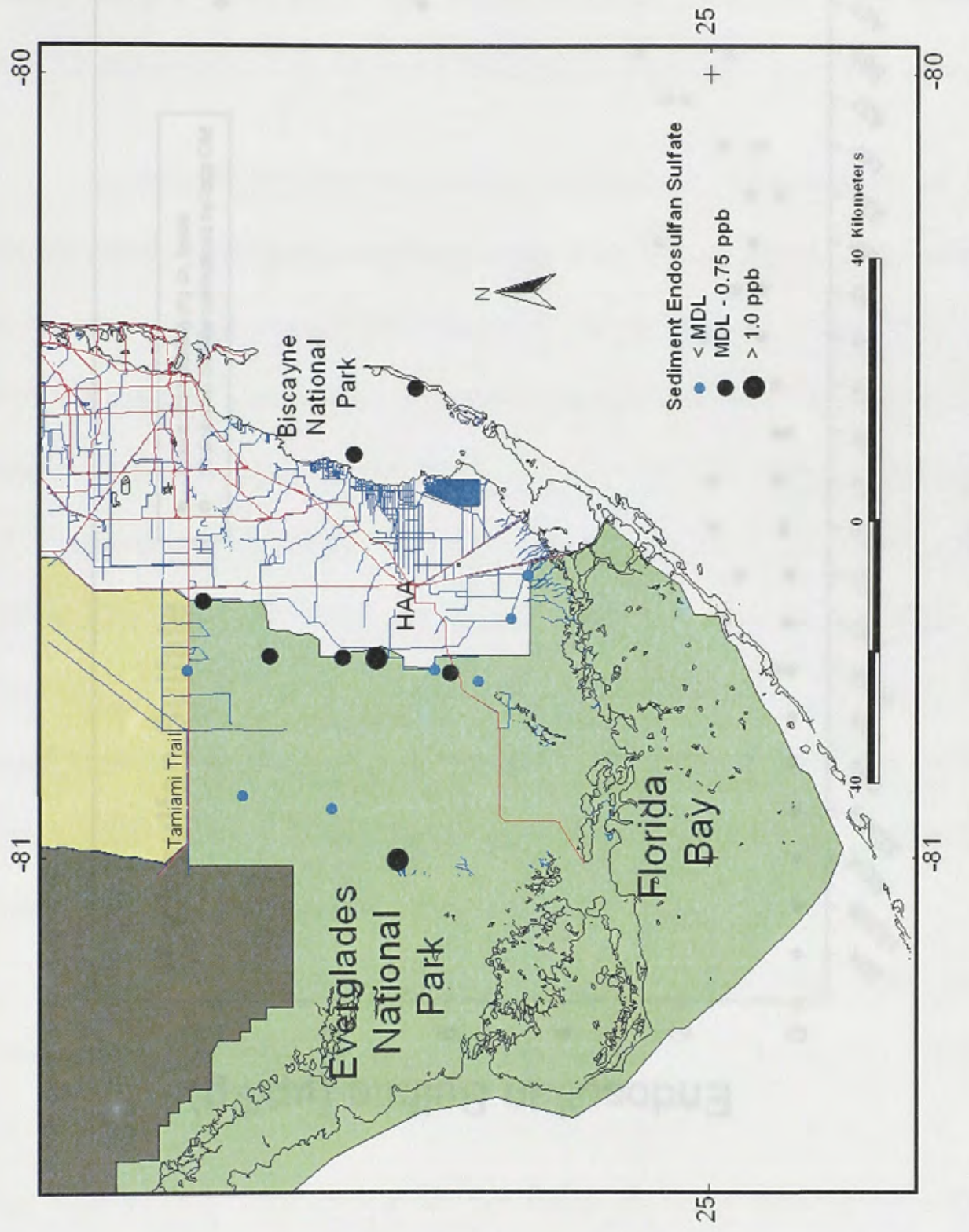

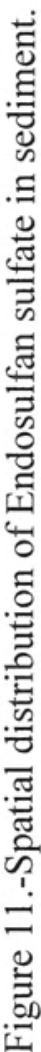




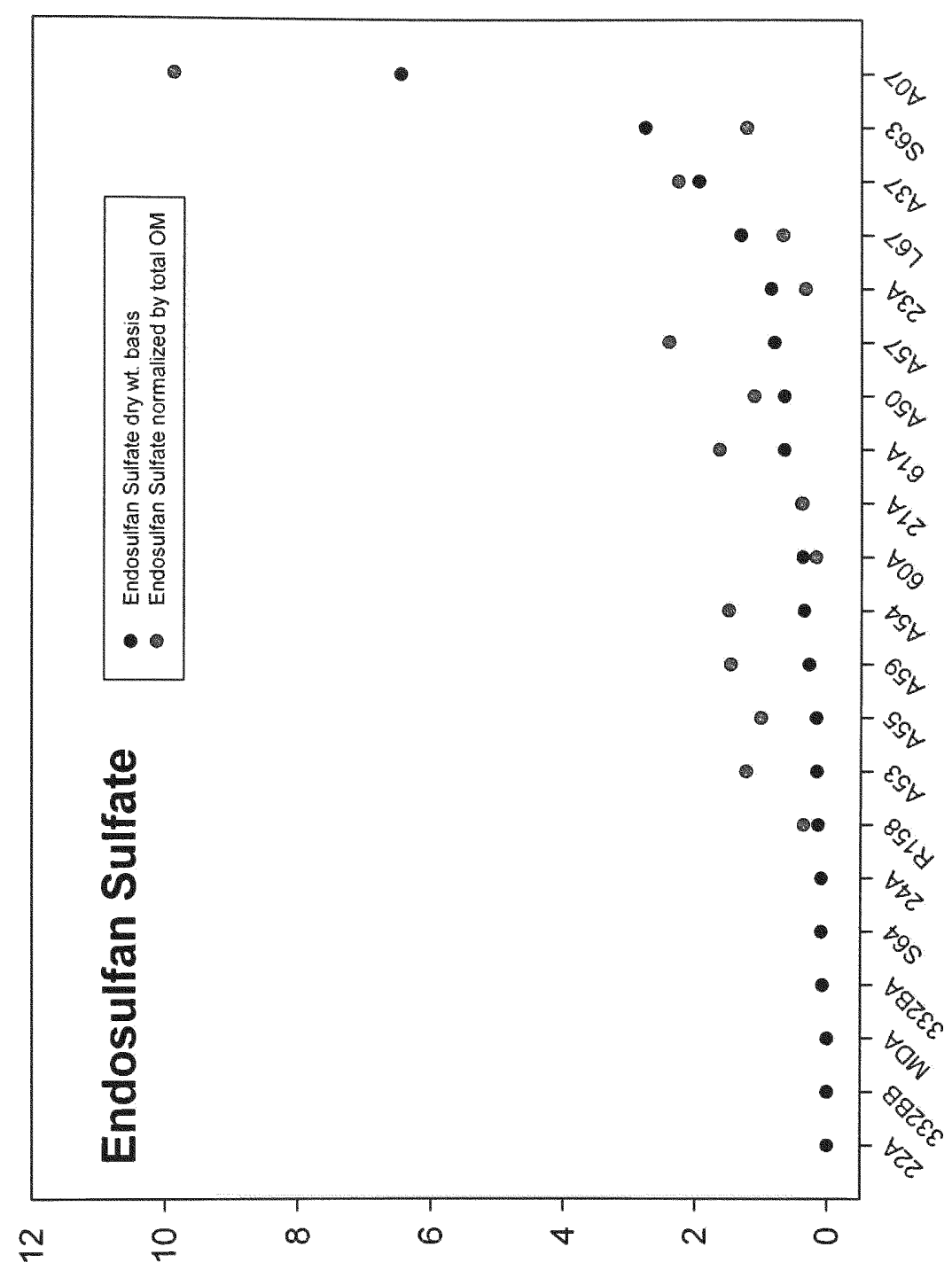

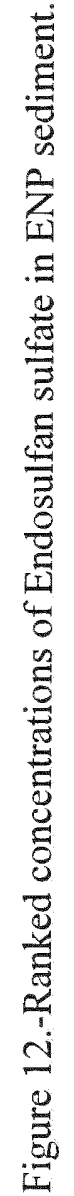

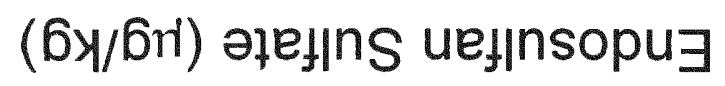


water quality criteria for $\alpha$ and $\beta$ endosulfan have been developed by the U.S. EPA and its applicability to this study will be discussed in more detail in the section concerning OCP contamination in fish tissue. Concentrations of $\alpha$ and $\beta$ endosulfan, and endosulfan sulfate along the park lands were much lower than those previously reported by Miles and Pfeuffer (1997) of 16, 24, and $1200 \mu \mathrm{g} / \mathrm{kg}$ respectively, in the C-111 canal.

In order to facilitate comparison of observed concentrations of contaminants throughout the study area, sampling stations were divided into six geographically distinct areas. For organic contaminants in sediments, the regions of interest are (1) the East Boundary, which is comprised of 7 stations along the eastern boundary of ENP which is adjacent to the Homestead Agricultural Area (HAA). (2) Taylor Slough which consists of 4 stations extending from near the southern entrance of ENP to near where Taylor Slough flows into Florida Bay. (3) Shark Slough, has 4 stations that transect the slough from just south of Tamiami Trail to the center of the park. (4) C-111, consists of 3 stations along (but not in) the C-111 canal which drains from the HAA. (5) BNP consists of the 9 stations sampled in the southern portion of Biscayne Bay. (6) Florida Bay which consists of 4 stations sampled in eastern Florida Bay.

Comparisons of the distribution of organic contaminants within the study area reveal some interesting results. As would be expected, the highest concentrations of OCPs were found along the Eastern Boundary stations nearest to the HAA. However, in the case of p-p'DDT, p-p'DDD, p-p'DDE, Dieldrin, Endosulfan sulfate, and $\beta$ Endosulfan, elevated concentrations were also detected in two stations located in the Shark Slough area. This is illustrated in figures $5-12$, which show that stations A07 and 
A37, which are both located in remote areas of ENP, have higher concentrations of these compounds than most other stations with in the park. It should be noted that both these stations have the highest total organic matter (OM) content $(>85 \%)$, and when concentrations are ranked normalized by total $\mathrm{OM}$, the data show higher concentrations in the East Boundary stations than in the Shark Slough stations as can be seen in figures 5 -8 , and 12. Additional sediment samples were collected from A07 and A37 in October 2002 , and the analysis of these samples revealed similar results indicating that indeed, this area of the park may be acting as a sink for organic contaminants. Similar observations were also made of dieldrin, endrin, and chlorpyrifos with regard to these sites, however at very low $(<1 \mathrm{ppb})$ concentrations.

Higher than expected concentrations of p-p'DDE were also detected in two of the Tamiami stations, S63 and S64, with S63 exceeding the TEL, both these stations also have high OM content, 86 and 49\% respectively. Surprisingly little if any OCPs were detected in the C-111 area, which drains the HAA. This could result from the fact that sediment samples were collected from an area that until recently was separated from the canal by a levee formed during its excavation which prevented water to flow into or from ENP. This levee was removed as part of the hydrology restoration to allow more freshwater to enter the park (U.S.A.C.E. 1999). This area should be further monitored to evaluate the impact of this change on the levels of agriculture related contaminants. Box plot graphs of the distributions of total DDTs, p-p'DDE, o-p'DDE/ $\alpha$-endosulfan, and endosulfan sulfate are shown in figures $13-17$. 




Figure 13.-Boxplot graph of total DDT distribution within study area.

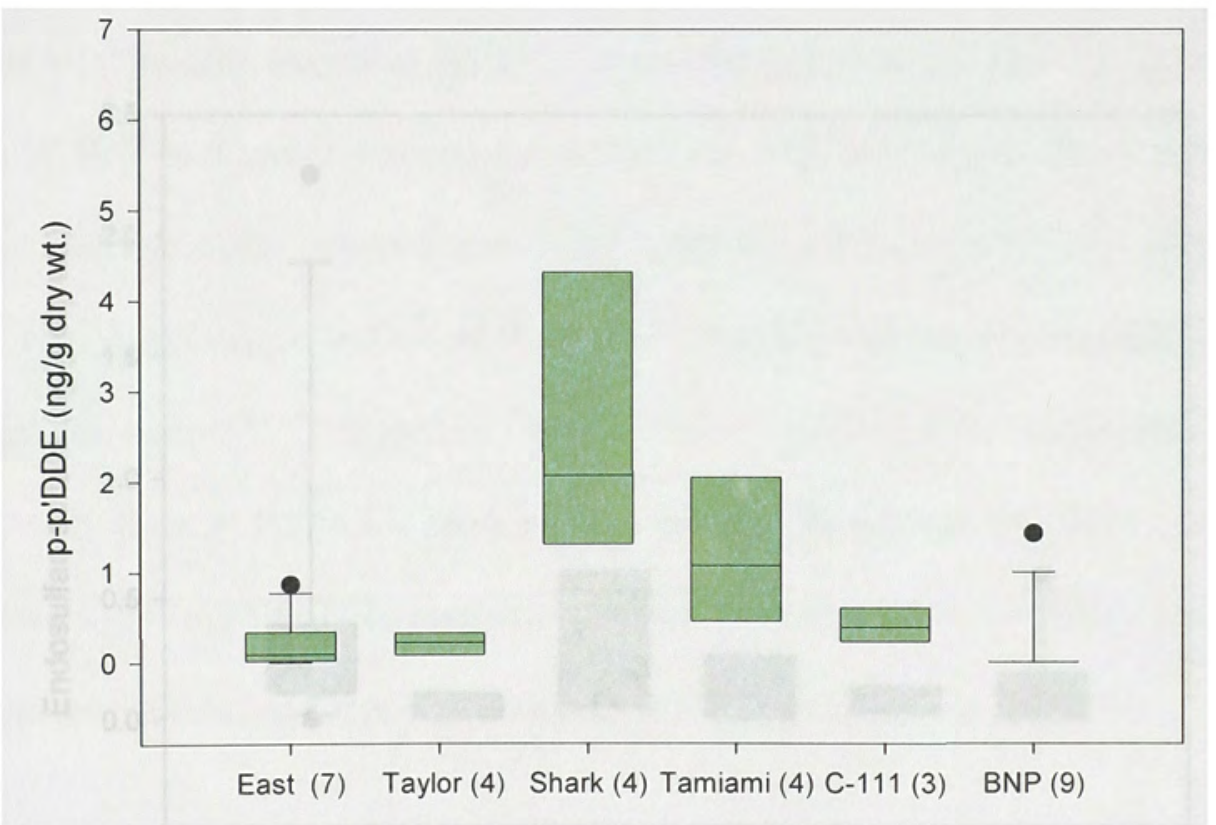

Figure 14.-Boxplot graph of p-p'DDE distribution within study area. 


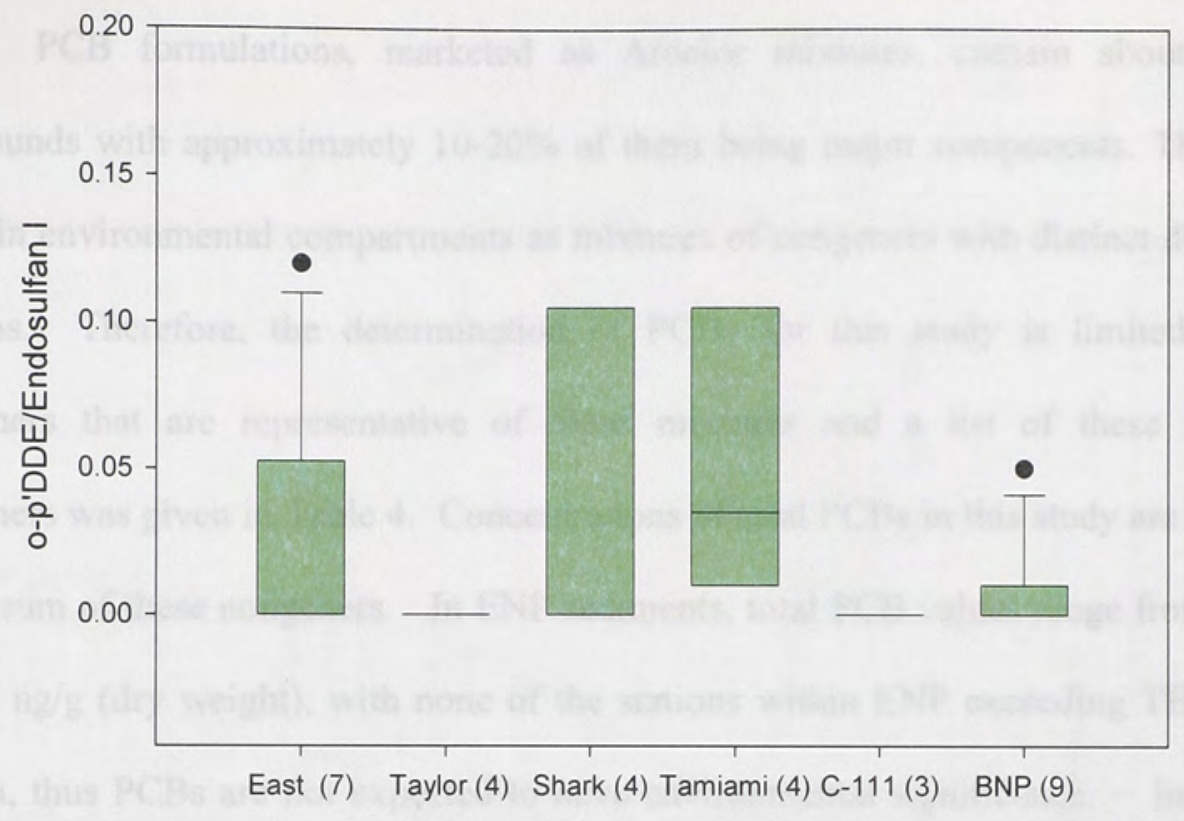

Figure 15.-Boxplot graph of o-p'DDE/ $\alpha$-endosulfan distribution within study area.

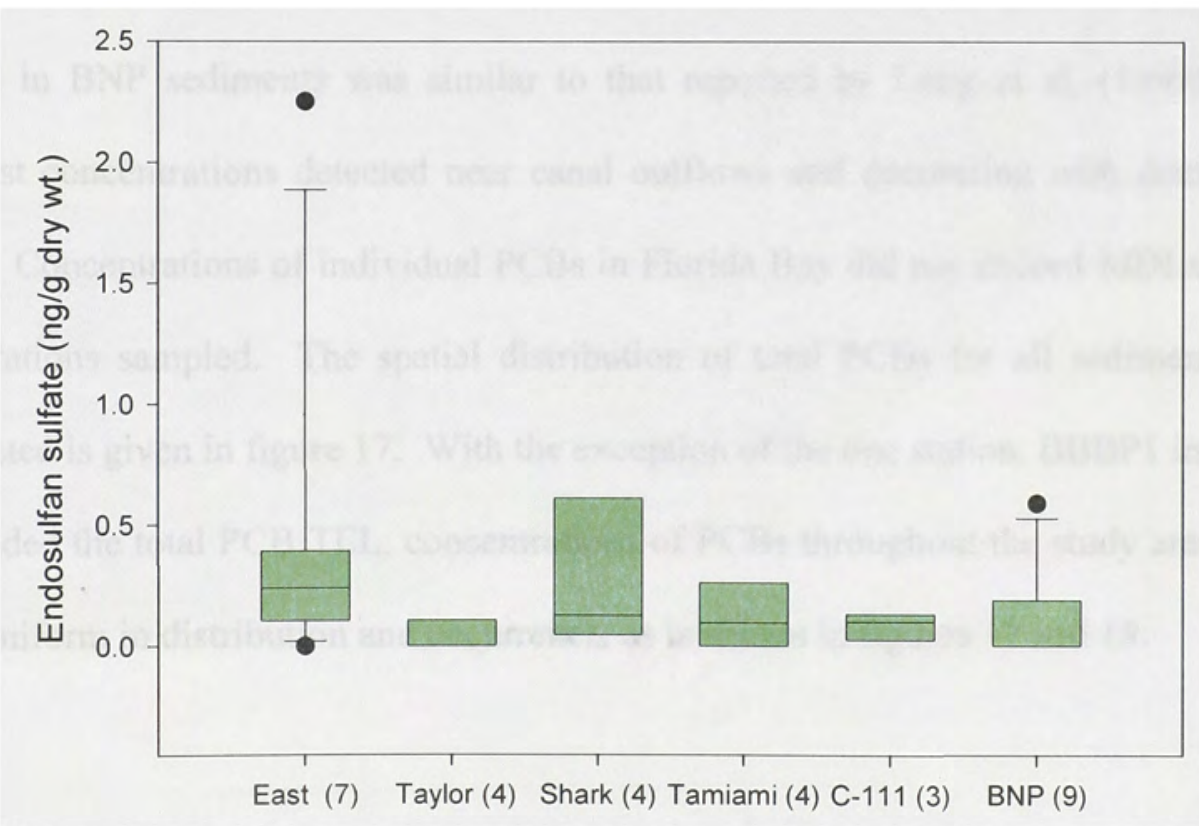

Figure 16.-Boxplot graph of Endosulfan sulfate distribution within study area. 


\subsubsection{Polychlorinated Biphenyls}

PCB formulations, marketed as Aroclor mixtures, contain about 100-110 compounds with approximately $10-20 \%$ of them being major components. Thus, PCBs occur in environmental compartments as mixtures of congeners with distinct distribution patterns. Therefore, the determination of PCBs for this study is limited to those congeners that are representative of these mixtures and a list of these individual congeners was given in Table 4. Concentrations of total PCBs in this study are expressed as the sum of these congeners. In ENP sediments, total PCB values range from $<\mathrm{MDL}$ $-7.10 \mathrm{ng} / \mathrm{g}$ (dry weight), with none of the stations within ENP exceeding TEL or PEL criteria, thus PCBs are not expected to have environmental significance. In Biscayne National Park, concentrations of total PCBs range from $<$ MDL - $42.02 \mathrm{ng} / \mathrm{g}$ (dry weight). One station in BNP, BBBP1, located in close proximity to Black Point Marina and the local landfill, exceeded the TEL but not the PEL criteria. The distribution of total PCBs in BNP sediments was similar to that reported by Long et al. (1999) with the highest concentrations detected near canal outflows and decreasing with distance from land. Concentrations of individual PCBs in Florida Bay did not exceed MDLs in any of the stations sampled. The spatial distribution of total PCBs for all sediment samples collected is given in figure 17. With the exception of the one station, BBBP1 in BNP that exceeded the total PCB TEL, concentrations of PCBs throughout the study area are low, and uniform in distribution and occurrence, as is shown in figures 17 and 18. 


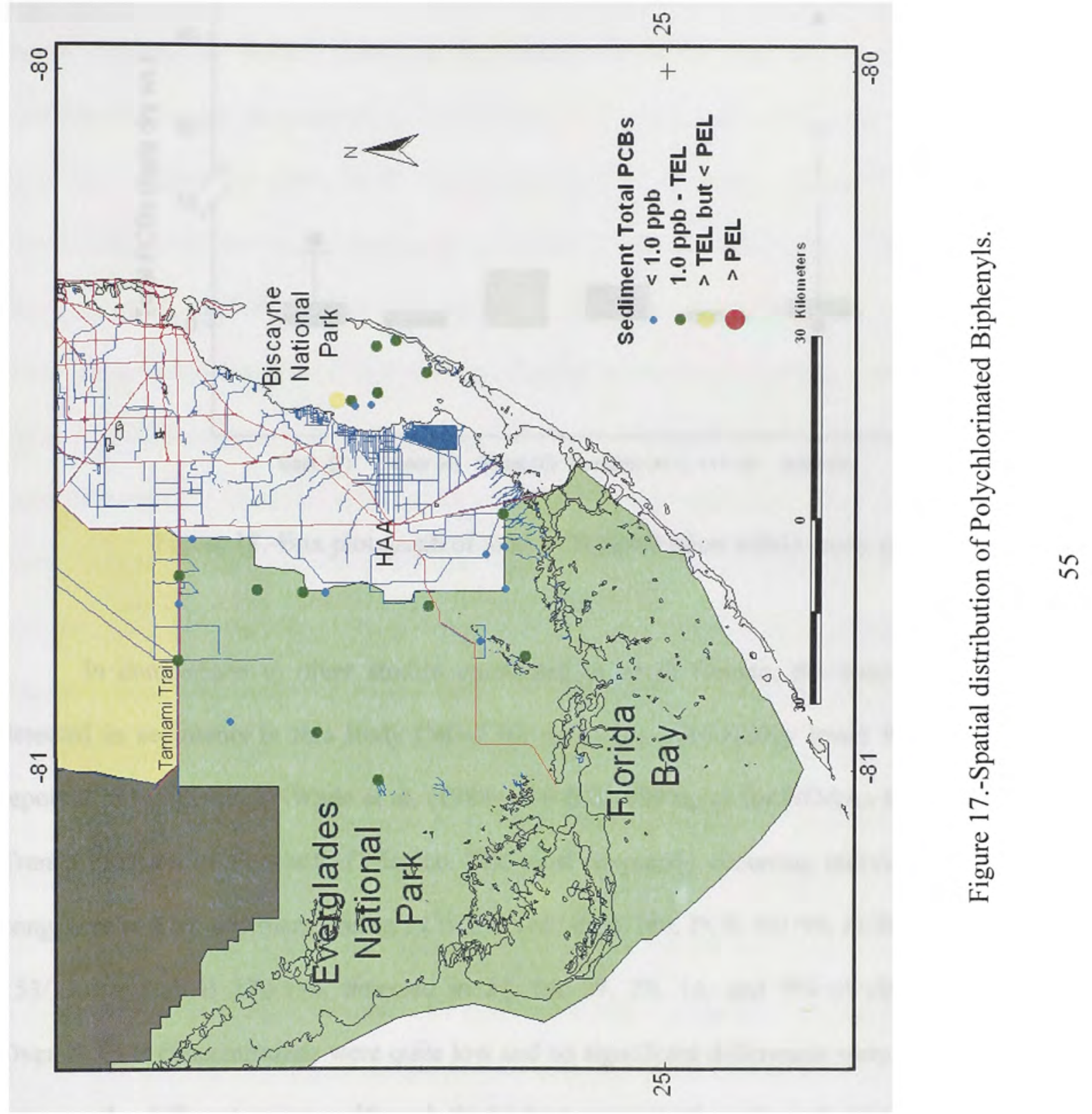




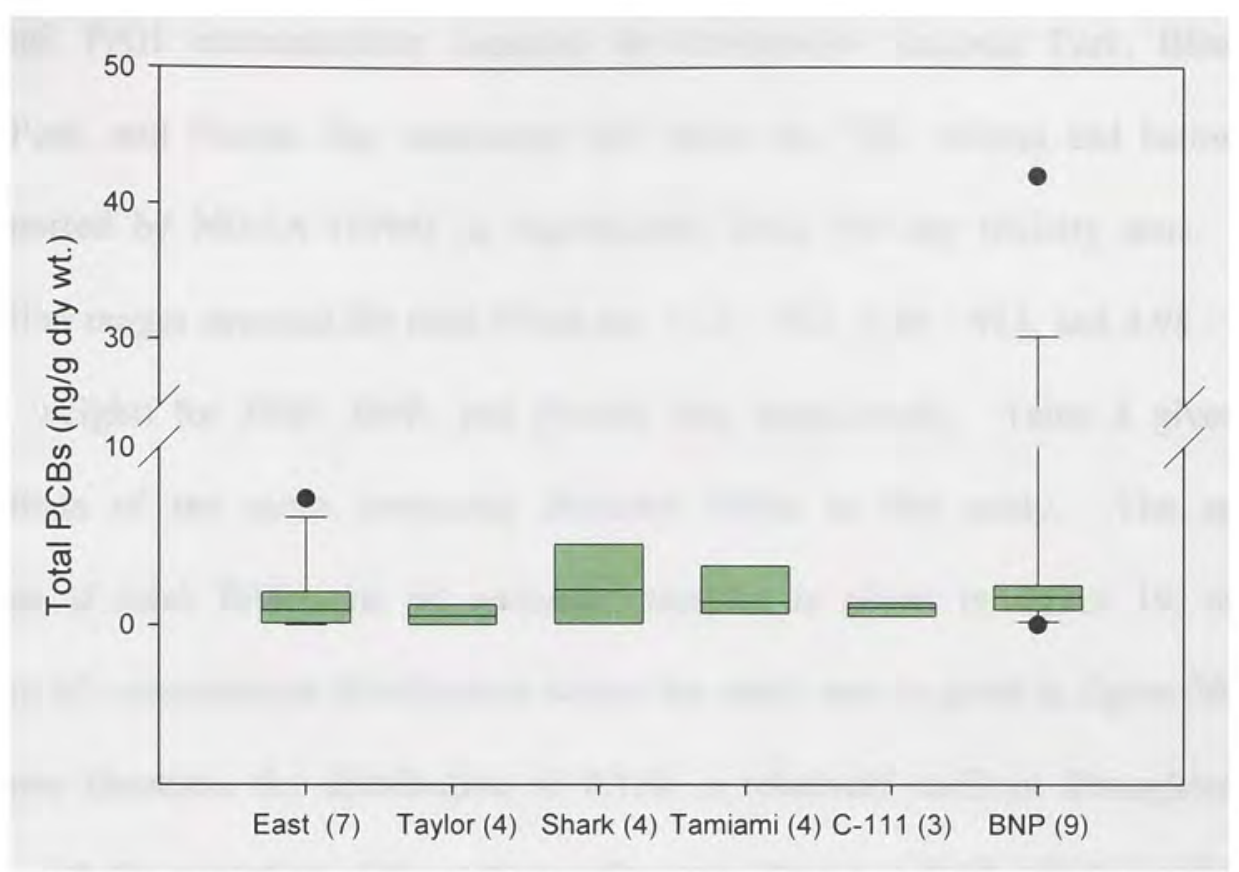

Figure 18.-Box plot graph of total PCB distribution within study area.

In comparison to other studies conducted in south Florida, the concentrations detected in sediments in this study (ND-7.10, ng/g) are considerably lower than those reported in sediments by Wade et al. (1988) of $(<0.01-189 \mathrm{ng} / \mathrm{g})$ for NOAAs Status and Trends Program in the Gulf of Mexico. The most frequently occurring individual PCB congeners in ENP sediments being PCB 138/160, PCB 180, PCB 101/90, PCB 29, PCB 153/132, and PCB 170/190, detected in $57,34,29,29,14$, and $9 \%$ of all stations. Overall, PCB concentrations were quite low and no significant differences were observed between the different regions, although the highest concentrations for individual samples were observed at BNP and the East Boundary of ENP. 


\subsubsection{Polycyclic Aromatic Hydrocarbons}

Total PAH concentrations detected for Everglades National Park, Biscayne National Park, and Florida Bay sediments fall below the TEL criteria and below the ranges reported by NOAA (1994) as significantly toxic for any toxicity tests. The concentration ranges detected for total PAHs are $15.3-682,1.48-912$, and $4.98-54.9$ $\mathrm{ng} / \mathrm{g}$ (dry weight) for ENP, BNP, and Florida Bay respectively. Table 8 gives the concentrations of the more frequently detected PAHs in this study. The spatial distribution of total PAHs for all sediment samples is given in figure 19, and a comparison of concentration distributions within the study area is given in figure 20 . As these figures illustrate, the distribution of PAHs is relatively uniform throughout the study area with the exception of the stations adjacent to Tamiami Trail, which are slightly more elevated than all other areas and one station in BNP in close proximity to a marina and the municipal landfill. The composition of PAHs detected in sediment samples consist of both low molecular weight (LMW) PAHs and high molecular weight (HMW) PAHs

One method commonly used to evaluate the sources of PAH emissions is to determine the ratio of benzo[a]pyrene (BaP)/benzo[ghi]perylene (BghiP) (Lang et al. 2002). Values of $\mathrm{BaP} / \mathrm{BghiP}$ from automobile emissions fall into the range between 0.30 -0.44 where as $\mathrm{BaP} / \mathrm{BghiP}$ values from sources such as coal combustion can be as high as 6.6. The average $\mathrm{BaP} / \mathrm{BghiP}$ values for this study are 0.89 and 0.91 for $\mathrm{ENP}$ and BNP sediment samples respectively; insufficient data were available for Florida Bay stations. These values from ENP and BNP indicate that the predominant source of PAHs detected 
in this study is automobile emissions. Thus, the higher levels observed for the Tamiami Trail area are likely due to street runoff from Route 41 (Tamiami Trail) into the park.

Table 8.-Concentrations of frequently detected PAHs in sediment samples.

Aralyte Mn Mex ConcentrationMban StanderdDeiation $>\mathrm{Ma}^{\mathrm{a}}$

\begin{tabular}{|c|c|c|c|c|c|}
\hline Tata PAHs with Peryene & 1.5 & 912 & 126 & 198 & \\
\hline Nepthalene & ND & 202 & 622 & 487 & $97 \%$ \\
\hline Bpheny & $\mathrm{ND}$ & 94 & 256 & 1.99 & $80 \%$ \\
\hline Phenantrene & ND & 192 & 399 & 4.75 & $71 \%$ \\
\hline Fuoranthene & NO & 74.8 & 837 & 15.2 & $71 \%$ \\
\hline Pyrene & $\mathrm{ND}$ & 666 & 6.92 & 13.7 & $63 \%$ \\
\hline Q2-Napthalene & ND & 161 & 399 & 4.34 & $60 \%$ \\
\hline Berrdghil peylene & ND & 69.8 & 5.60 & 135 & $60 \%$ \\
\hline Benzolojfluoranthene & ND & 108 & 11.0 & 240 & $57 \%$ \\
\hline 1-Methynapthalene & $\mathrm{ND}$ & 4.20 & 1.13 & 1.13 & $51 \%$ \\
\hline Benzolkfluaranthene & $\mathrm{ND}$ & 681 & 6.23 & 136 & $49 \%$ \\
\hline Benzolejpyrene & ND & 75.6 & 66 & 15.1 & $49 \%$ \\
\hline Indend $1,2,3,-c$, djpyrene & ND & 86.5 & 6.04 & 15.80 & $46 \%$ \\
\hline BenzdialAntracene & $\mathrm{ND}$ & 37,0 & 297 & 691 & $43 \%$ \\
\hline Berzolajpyrene & No & 63.4 & 4.62 & 11.80 & $40 \%$ \\
\hline Florene & $N$ & 49 & 0.85 & 1.25 & $31 \%$ \\
\hline
\end{tabular}

Velues in ngg by weight.

${ }^{a}$ Percentage of total samples $(\mathrm{N}=34)$ above method detection limit (MD). 


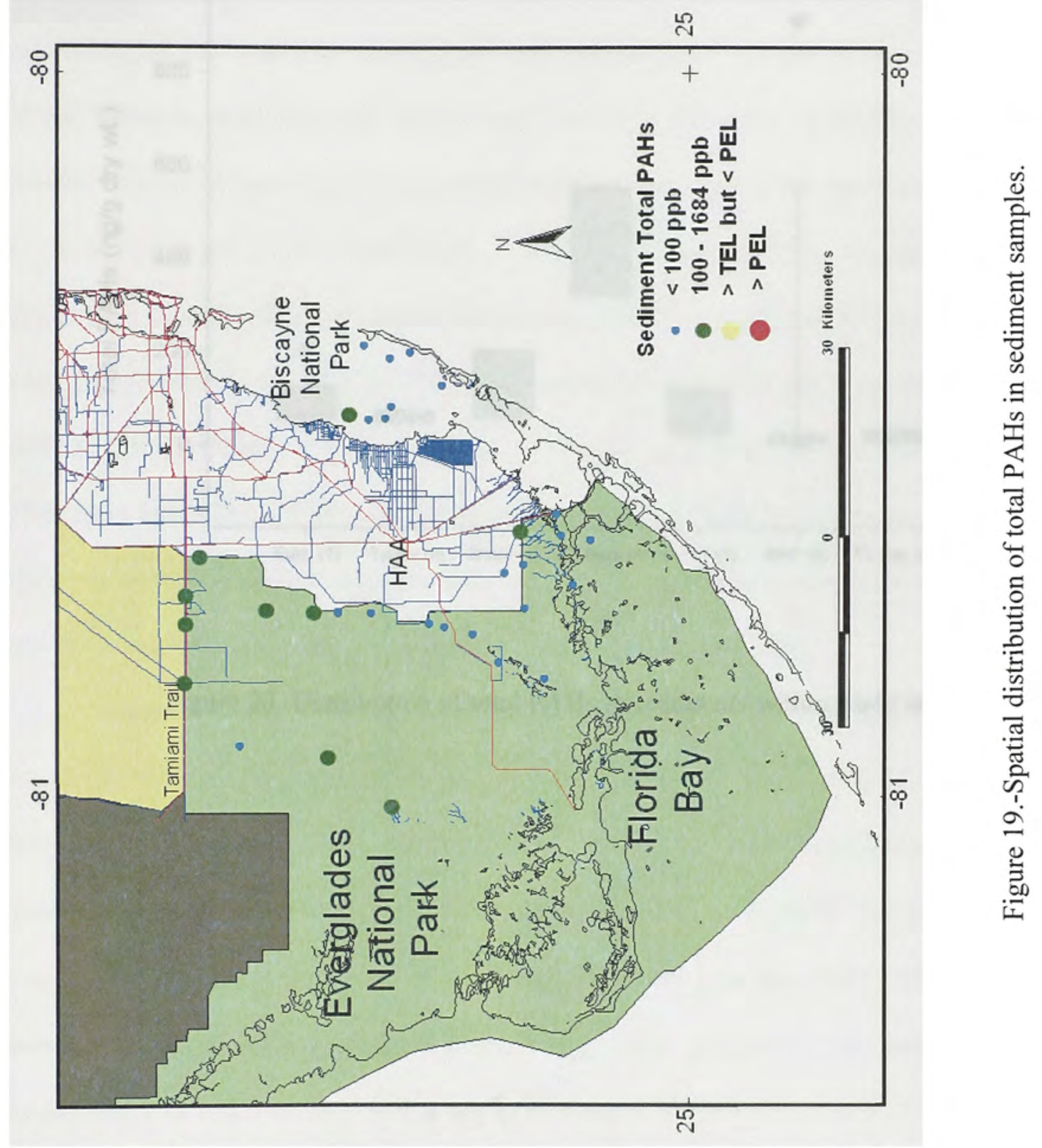




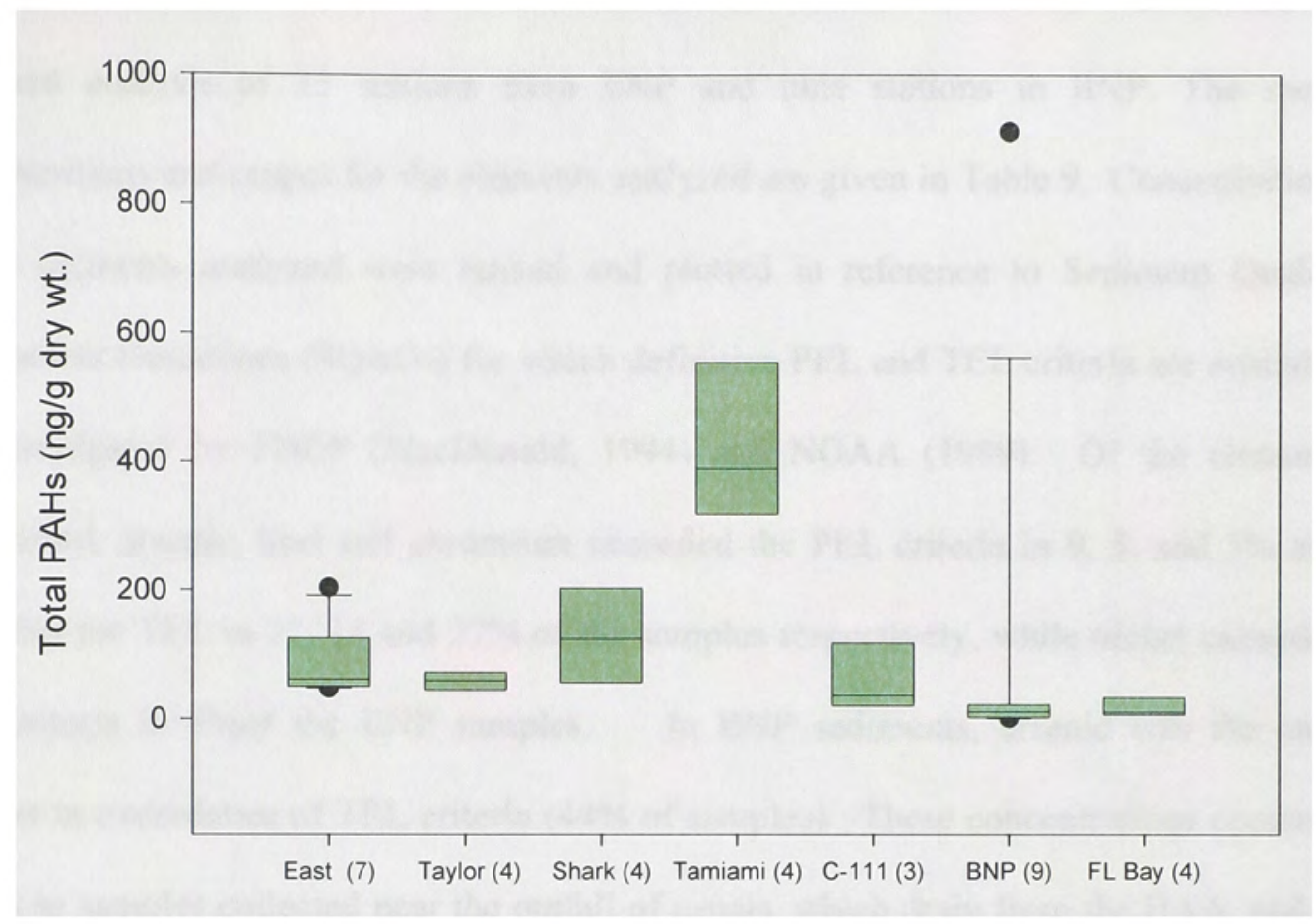

Figure 20.-Distribution of total PAHs in sediments within study area. 


\subsubsection{Trace Elements in Sediment}

Eleven elements ( $\mathrm{Be}, \mathrm{V}, \mathrm{Cr}, \mathrm{Co}, \mathrm{Ni}, \mathrm{Cu}, \mathrm{Zn}, \mathrm{As}, \mathrm{Cd}, \mathrm{Pb}$, and $\mathrm{Al}$ ) were chosen for sediment analysis of 22 stations from ENP and nine stations in BNP. The mean concentrations and ranges for the elements analyzed are given in Table 9. Concentrations of the elements analyzed were ranked and plotted in reference to Sediment Quality Assessment Guidelines (SQAGs) for which definitive PEL and TEL criteria are available as promulgated by FDEP (MacDonald, 1994) and NOAA (1999). Of the elements determined, arsenic, lead and chromium exceeded the PEL criteria in 9, 5, and 5\% and exceeded the TEL in 32,14 and $27 \%$ of the samples respectively, while nickel exceeded TEL criteria in 5\%of the ENP samples. In BNP sediments, arsenic was the only element in exceedance of TEL criteria ( $44 \%$ of samples). These concentrations occurred mostly in samples collected near the outfall of canals, which drain from the HAA, and at one of the stations near Black Point Marina and the municipal landfill.

The arsenic values obtained in this study for ENP $(0.97-20.48 \mathrm{mg} / \mathrm{kg})$, fall within the range reported as background for undisturbed Florida soils $(0.01-38.2 \mathrm{mg} / \mathrm{kg})$, however, the mean obtained in this study $(6.07 \mathrm{mg} / \mathrm{kg})$ is higher than that reported for disturbed Florida soils $(1.43 \pm 4.59 \mathrm{mg} / \mathrm{kg}$ ) (Chen 2001). For BNP the mean value obtained for arsenic in this study of $7.45 \mathrm{mg} / \mathrm{kg}$ is lower than the NS\&T US sediment average of $10.3 \mathrm{mg} / \mathrm{kg}$ but higher than the NS\&T value reported for the mouth of the Miami River in Biscayne Bay of $5.1 \mathrm{mg} / \mathrm{kg}$ (Valette-Silver 1999). Lead concentrations detected in sediment samples in this study range from $1.8-251 \mathrm{mg} / \mathrm{kg}$ with an average of $26 \mathrm{mg} / \mathrm{kg}$. These figures, however are skewed by the presence of one sample collected in 


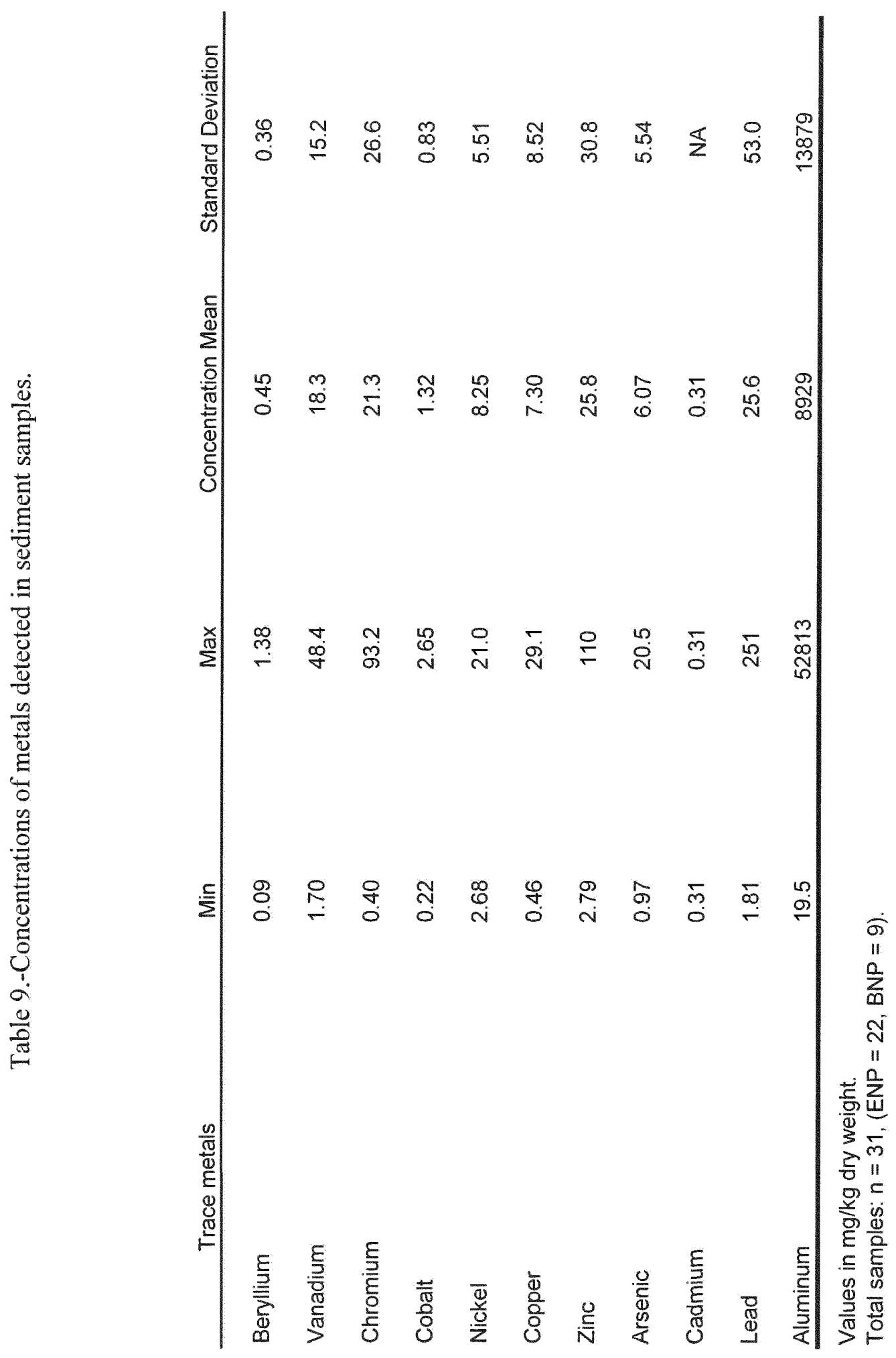


an area that appeared to be proliferated with lead bullet casings, therefore the median value for lead of $4.07 \mathrm{mg} / \mathrm{kg}$ is a better indicator of the lead concentrations detected in ENP sediments. This value falls within the lower end of the concentration range (3-40 $\mathrm{mg} / \mathrm{kg}$ ) detected in the Barron River Canal and Turner Rivers of Big Cypress National Preserve (Miller and Mcpherson, 1998). This value also falls well below the median values obtained from samples collected in residential, commercial, and public park areas in Miami and Gainesville, Florida (Chirenje et al. 2004). The range and average values of chromium $(0.40-93.24,21.32 \mathrm{mg} / \mathrm{kg})$ also appear to be skewed by a few samples with elevated concentration, the median value of $6.06 \mathrm{mg} / \mathrm{kg}$ however, falls at the lower end of the range $(6-77 \mathrm{mg} / \mathrm{kg})$ detected in Big Cypress by Miller and Mcpherson (1998). The ranges of copper and nickel concentrations detected in this study are in agreement with those reported in the Big Cypress study.

Figures $21-26$ show plots of element concentrations in reference to TEL and PEL criteria for those elements that exceeded TELs in ENP and BNP. Of the elements analyzed, only arsenic concentrations fell within the range for significantly toxic sediments reported by NOAA for Tampa Bay based on amphipod and Microtox ${ }^{\mathrm{TM}}$ bioluminescence tests (NOAA, 1994). Figures 27 - 35 show the spatial distribution of trace metals in sediments from all stations sampled. 


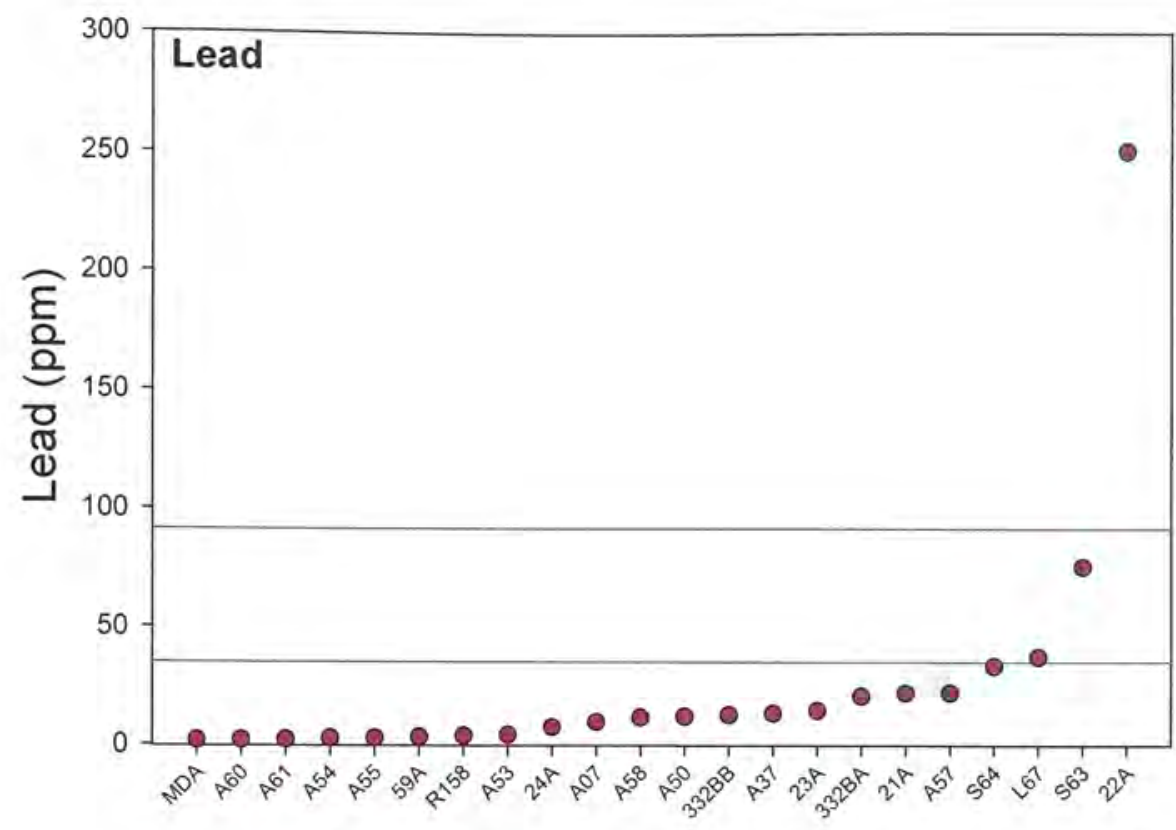

PEL

TEL

Station

Figure 21.-Ranked concentrations of lead in ENP sediment.

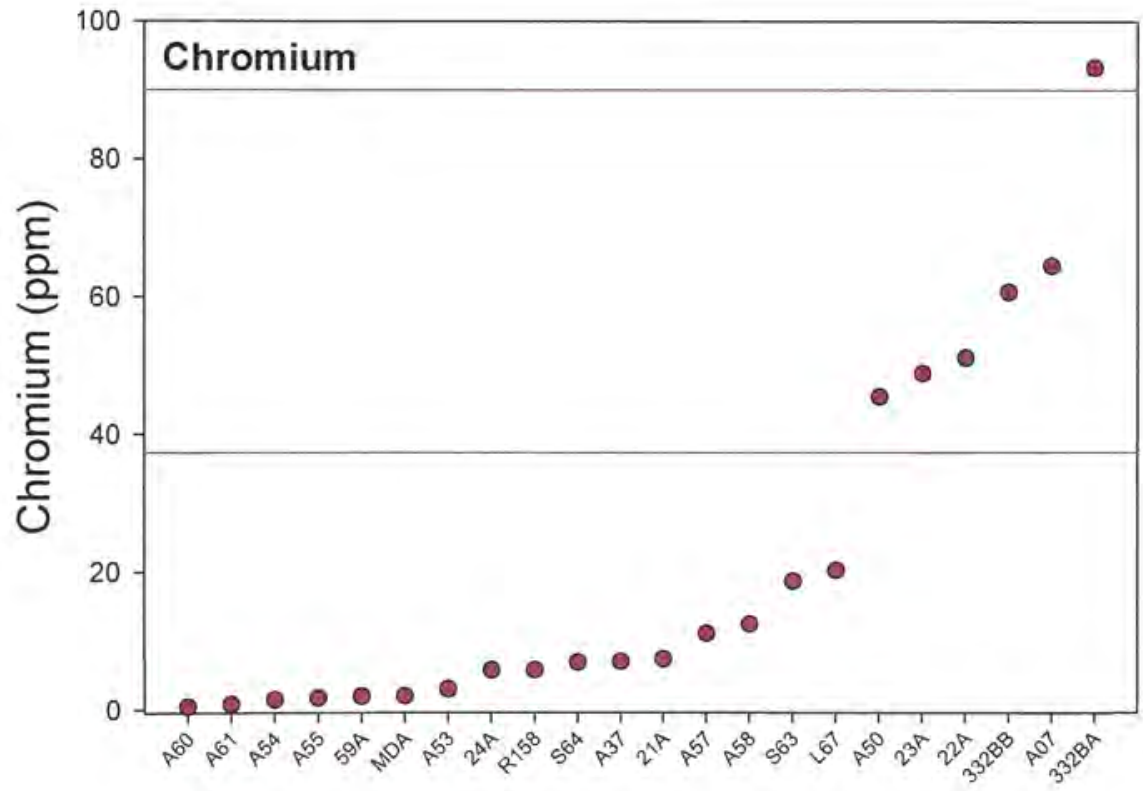

PEL

TEL

Station

Figure 22.-Ranked concentrations of chromium in ENP sediments. 


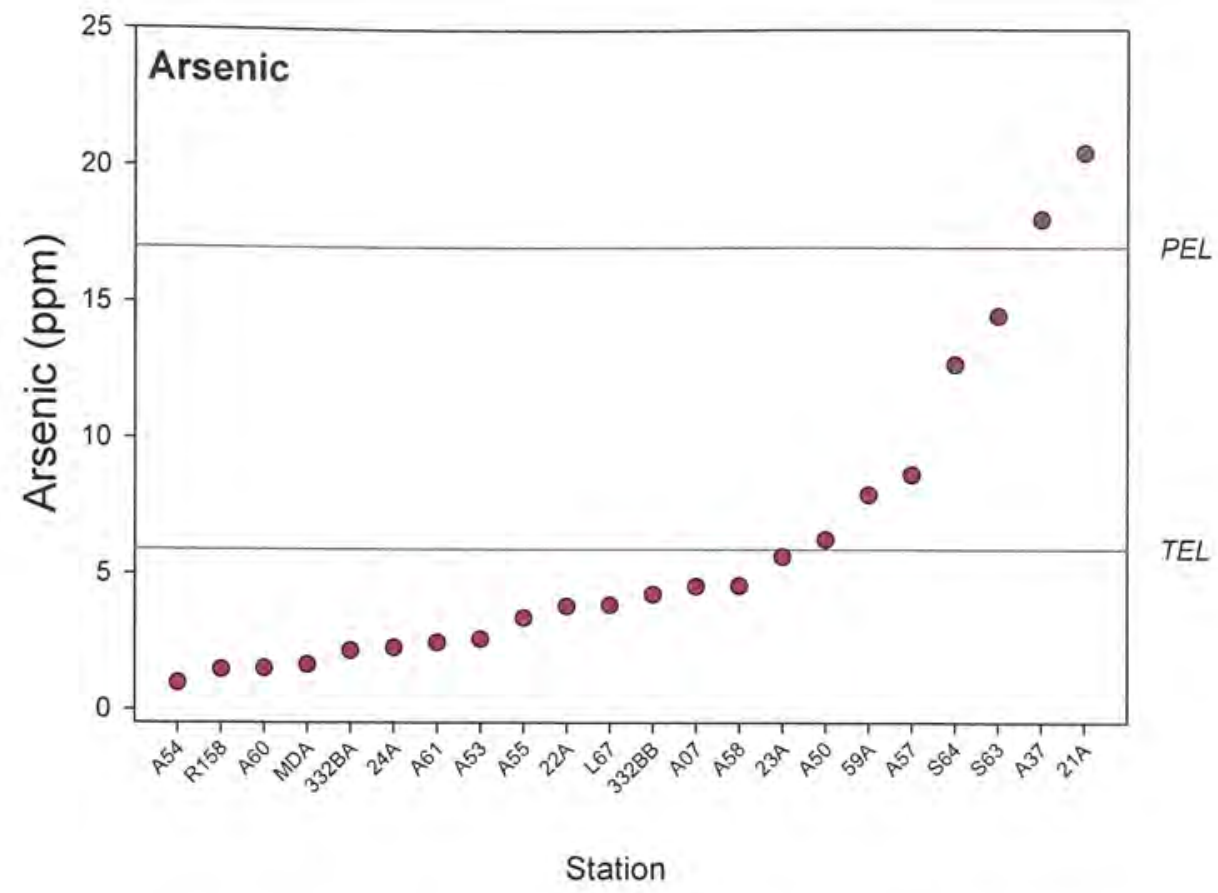

Figure 23.-Ranked concentrations of arsenic in ENP sediments.

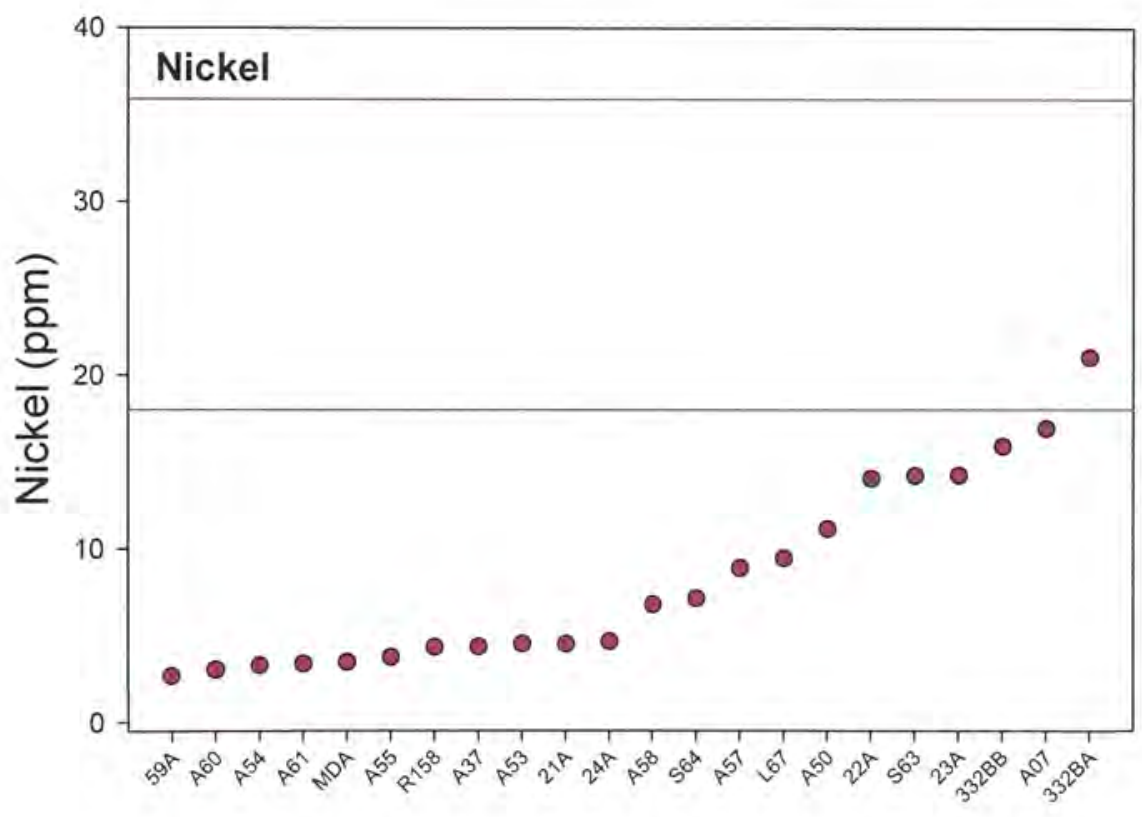

PEL

TEL

\section{Station}

Figure 24.-Ranked concentrations of nickel in ENP sediments. 


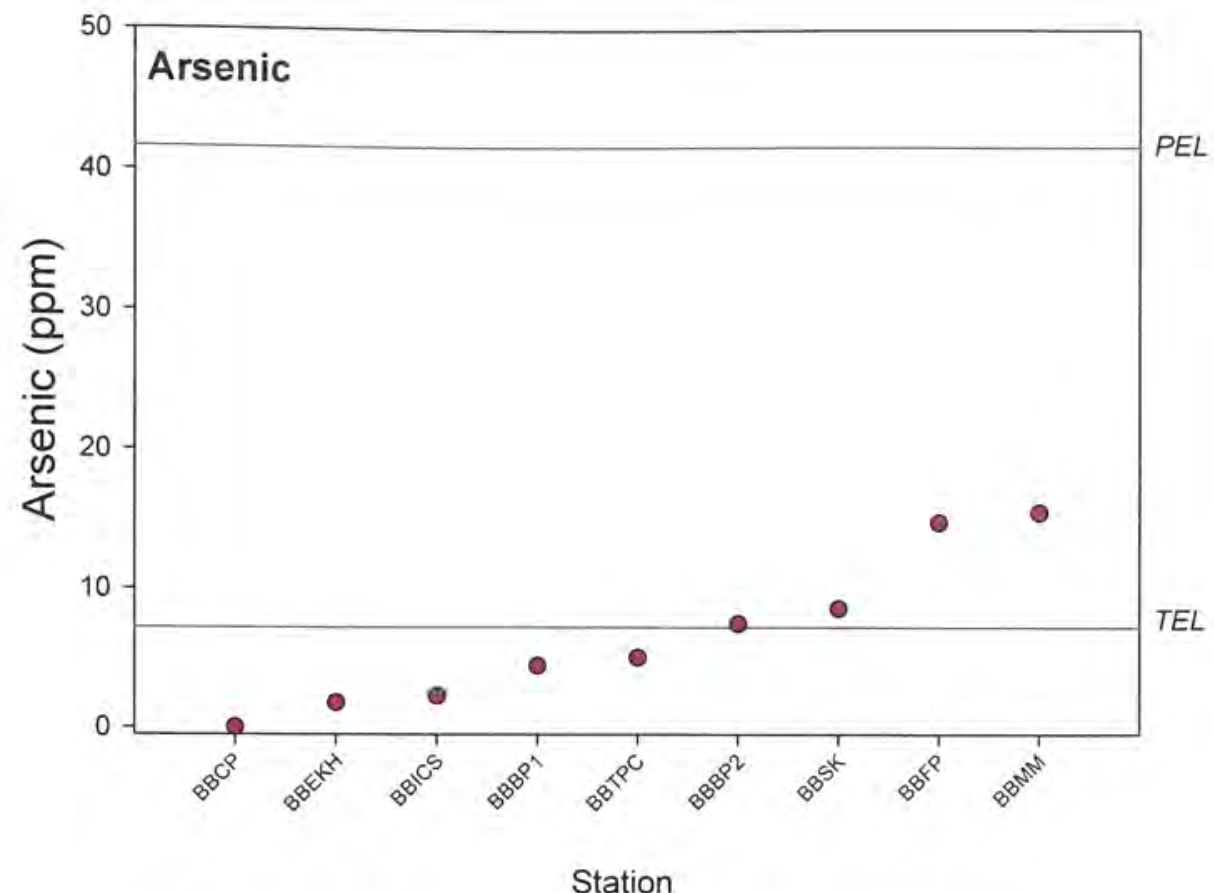

Figure 25.-Ranked concentrations of arsenic in BNP sediments. 


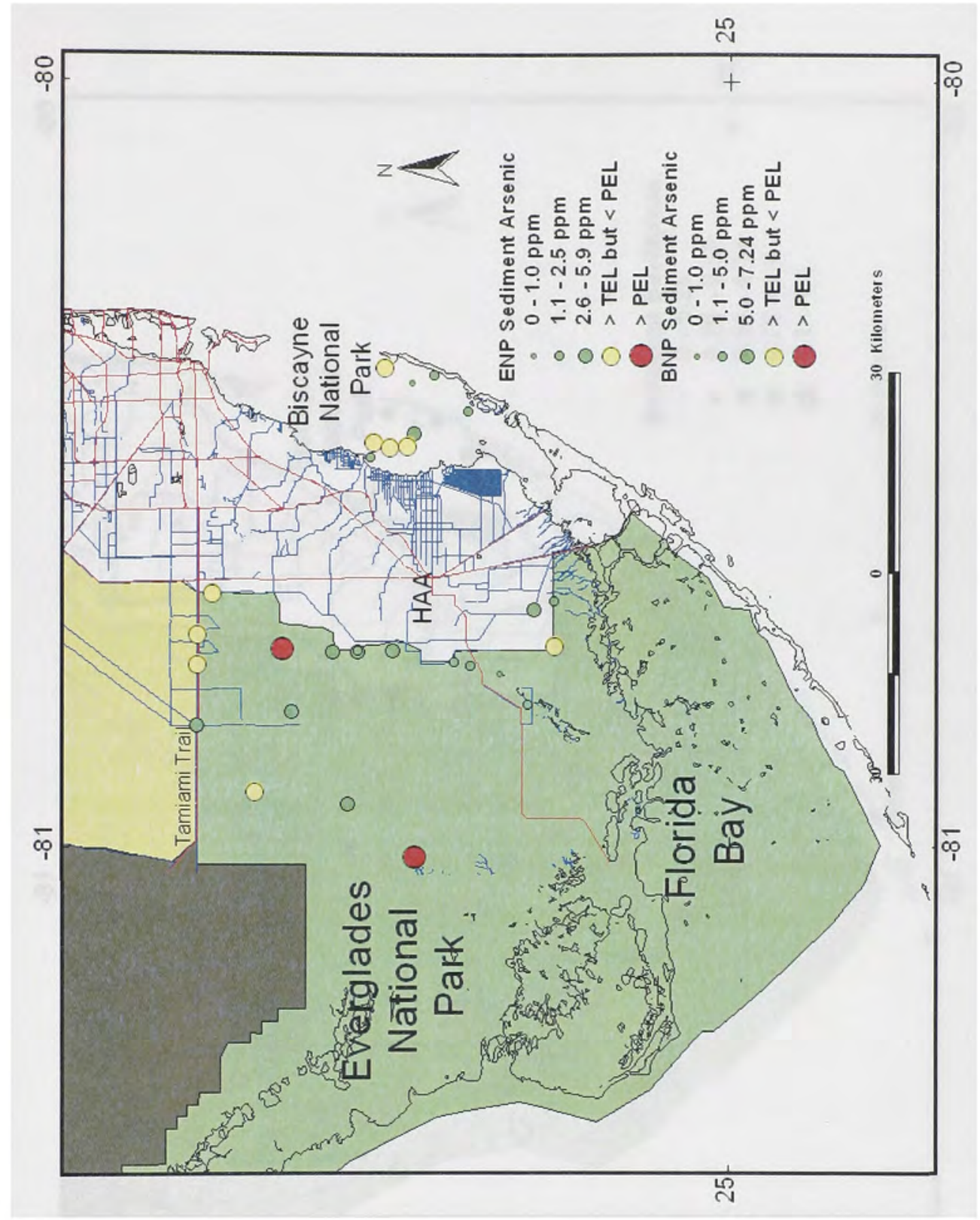

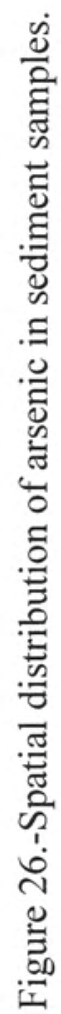




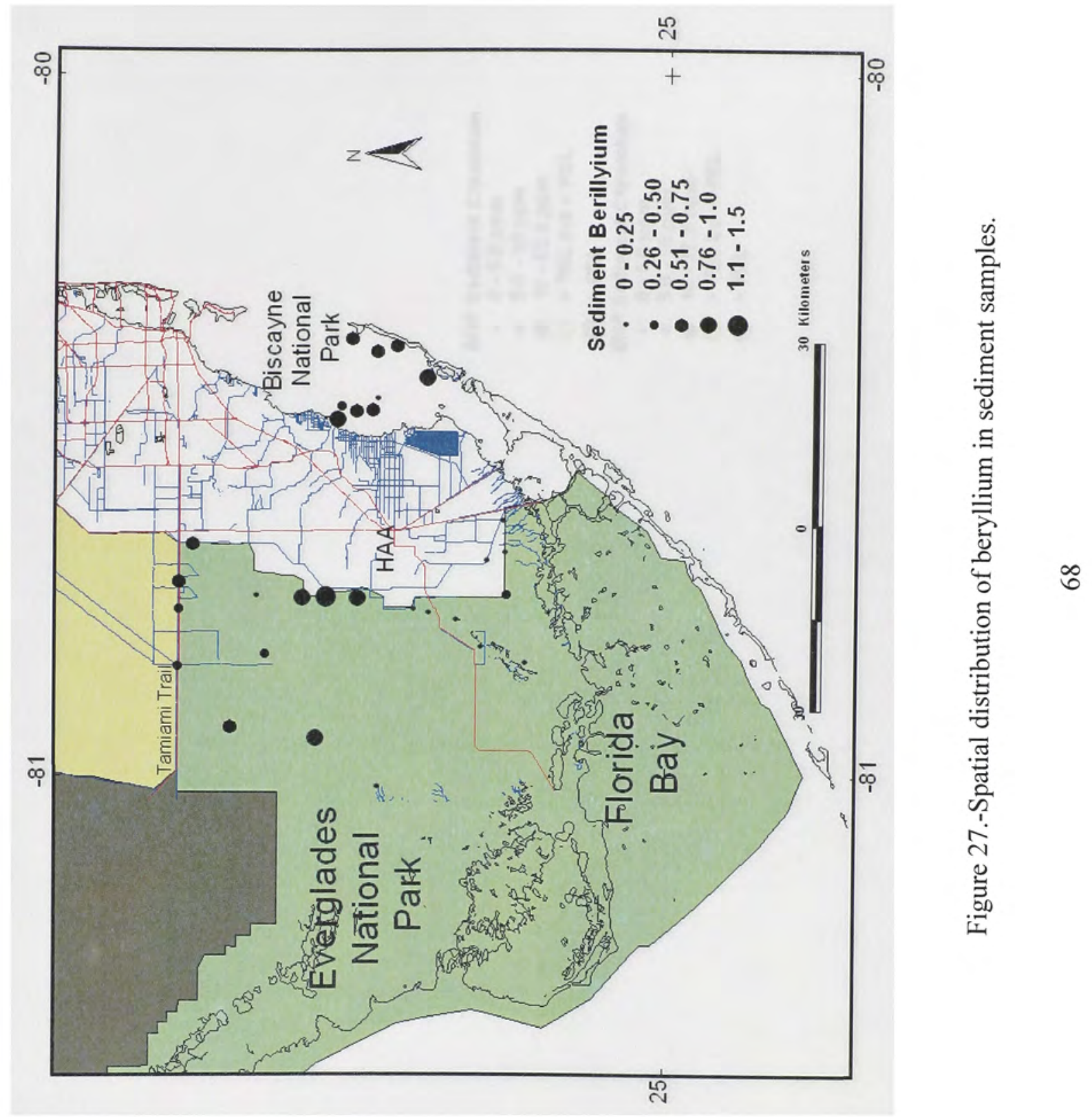




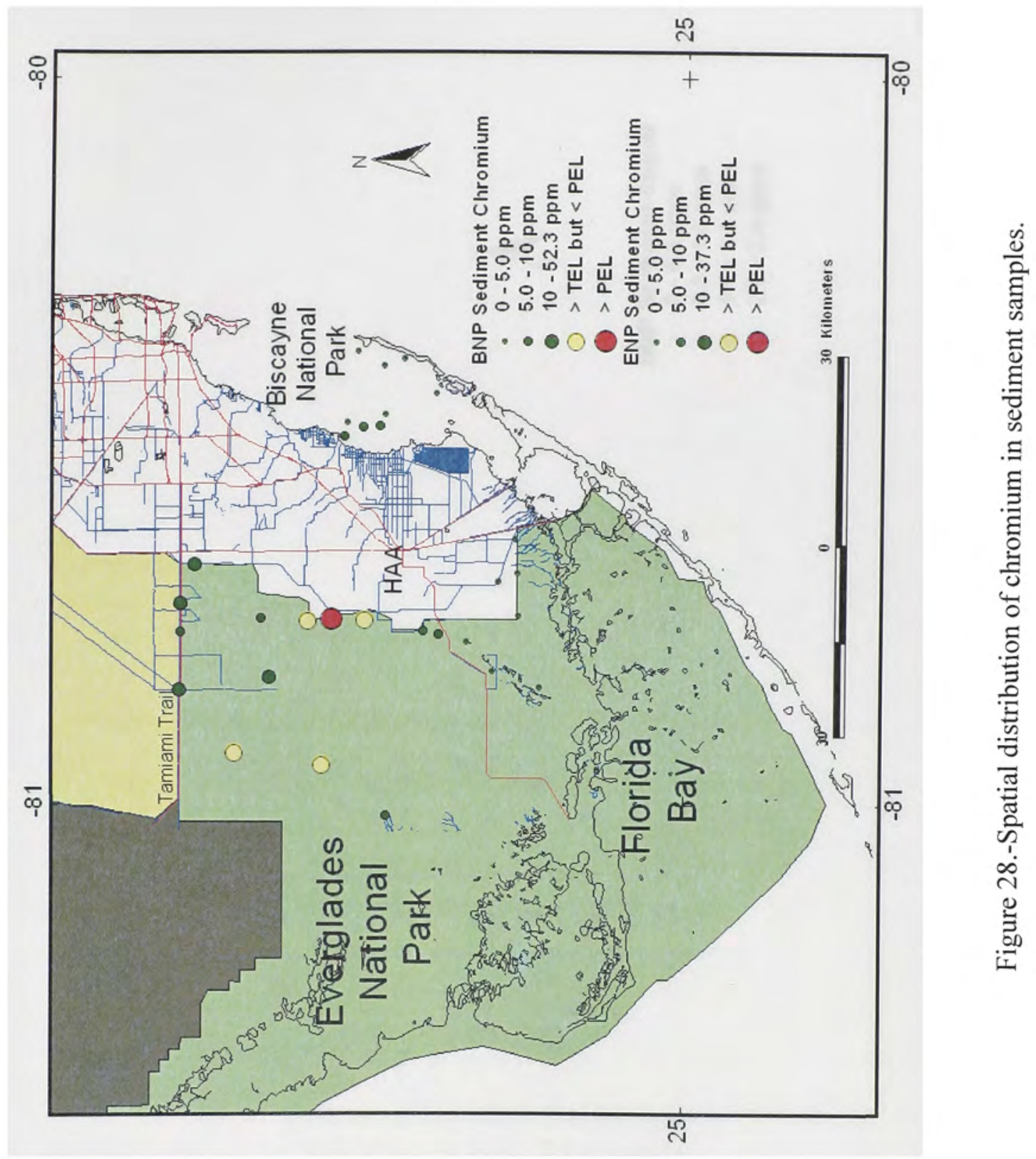




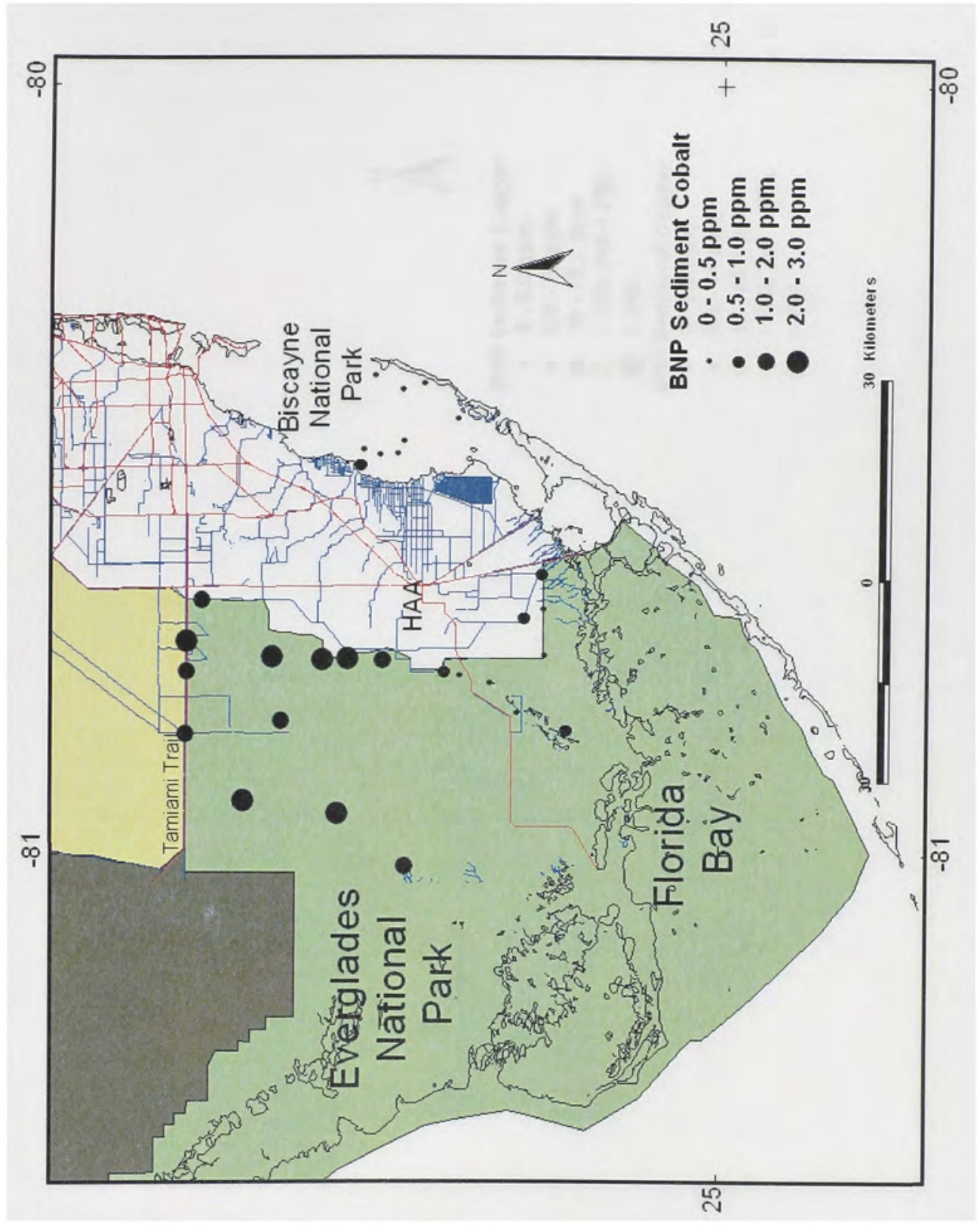

告 


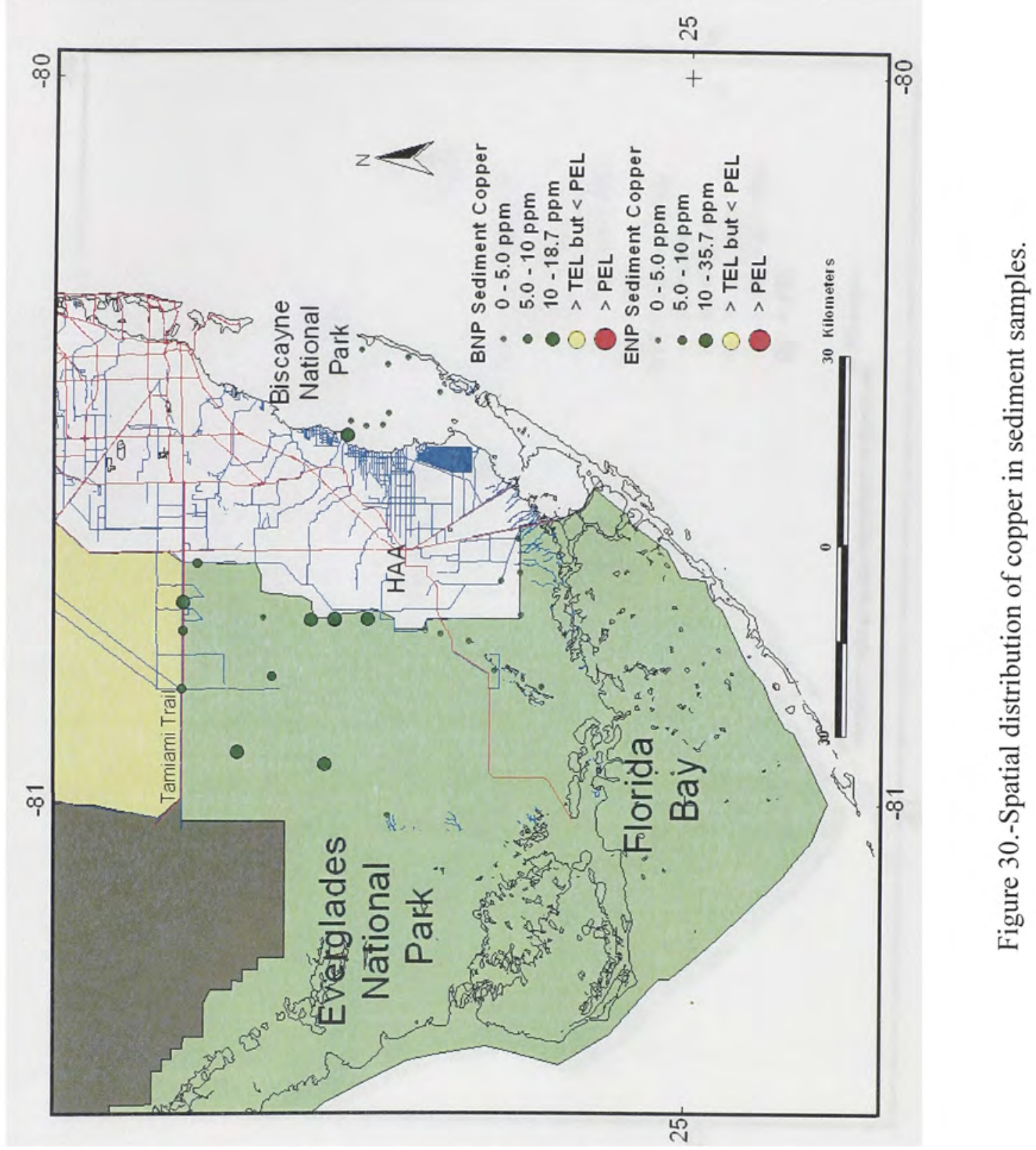




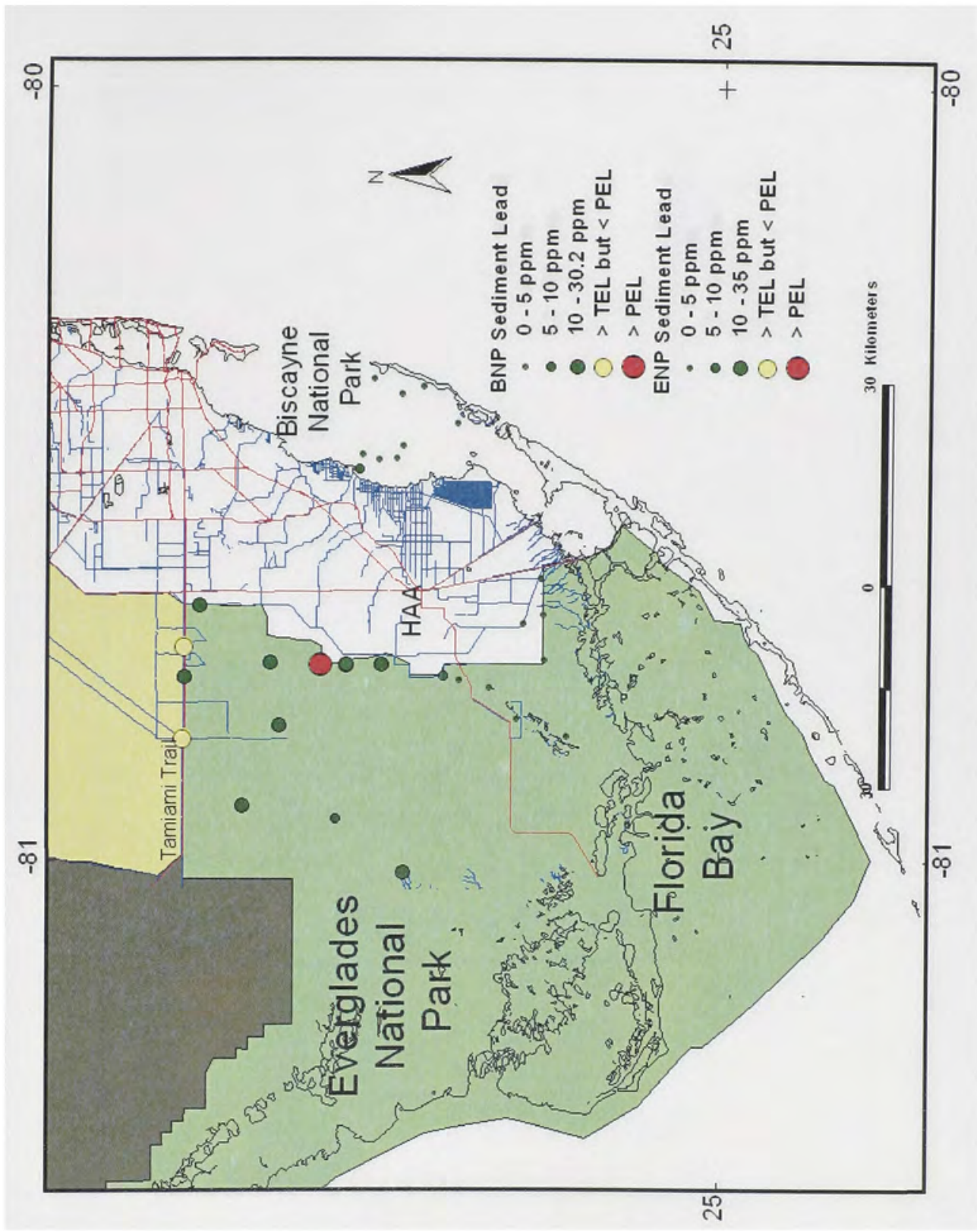

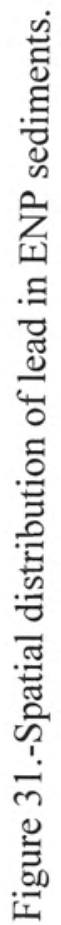




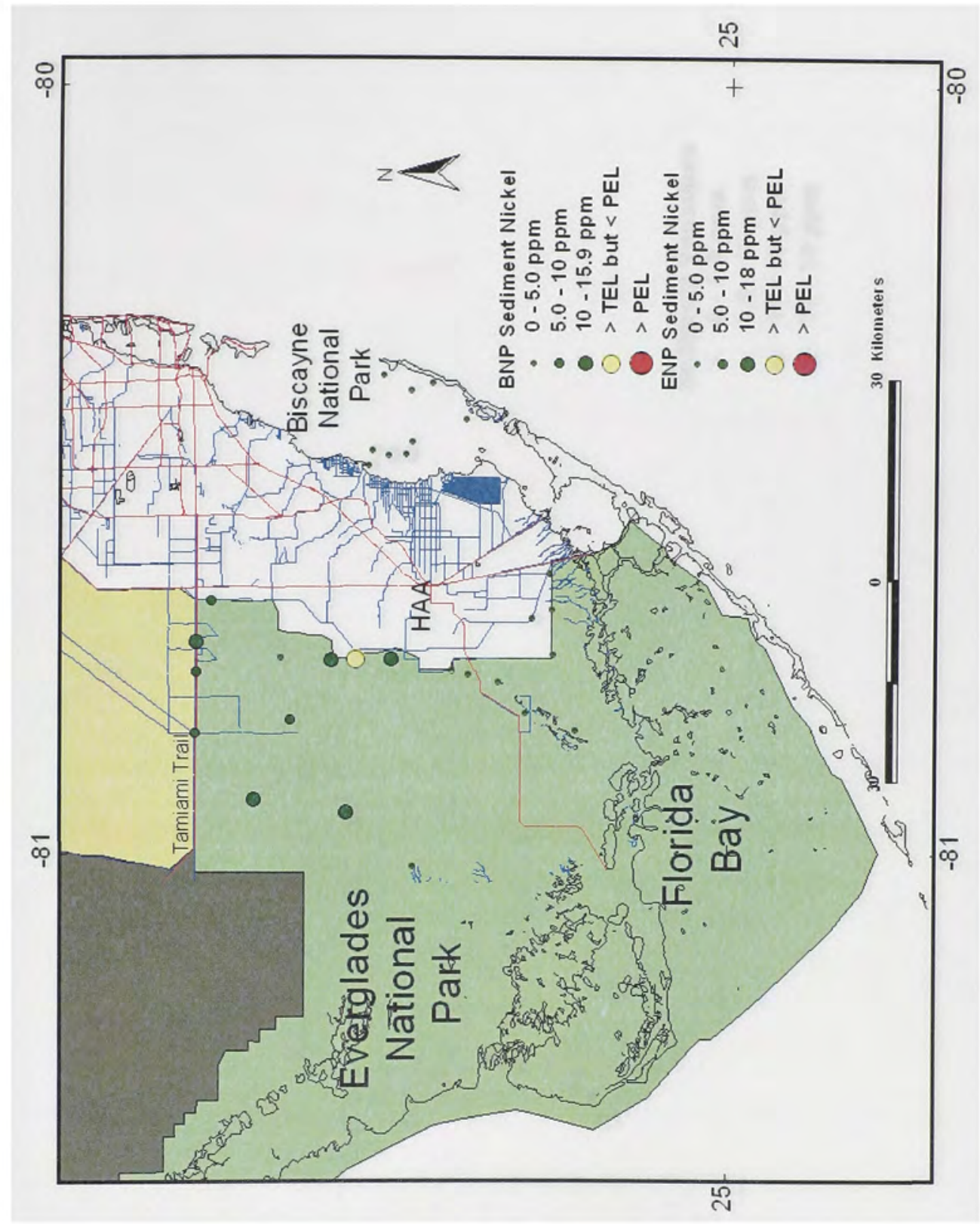

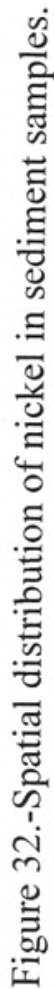




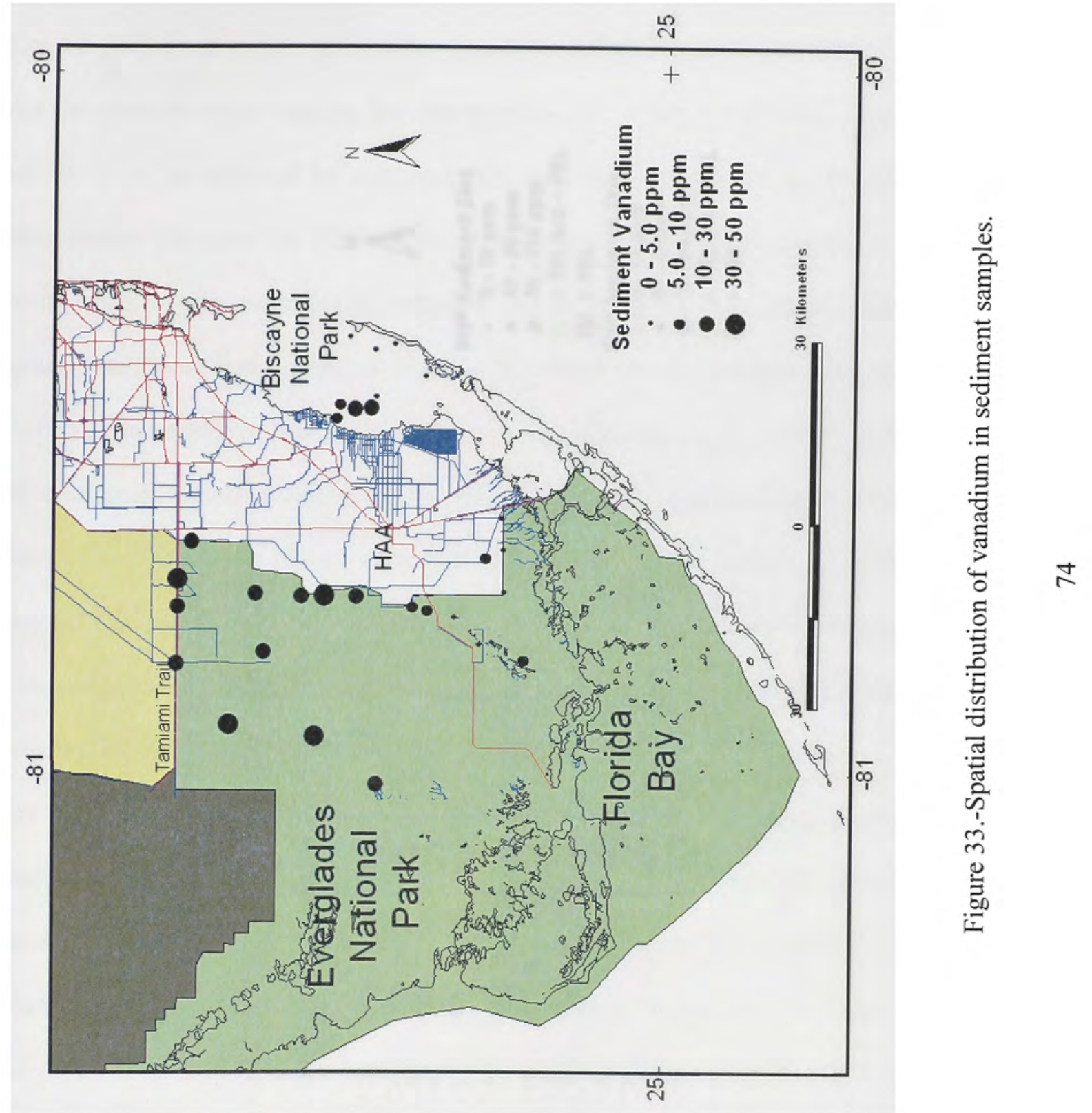




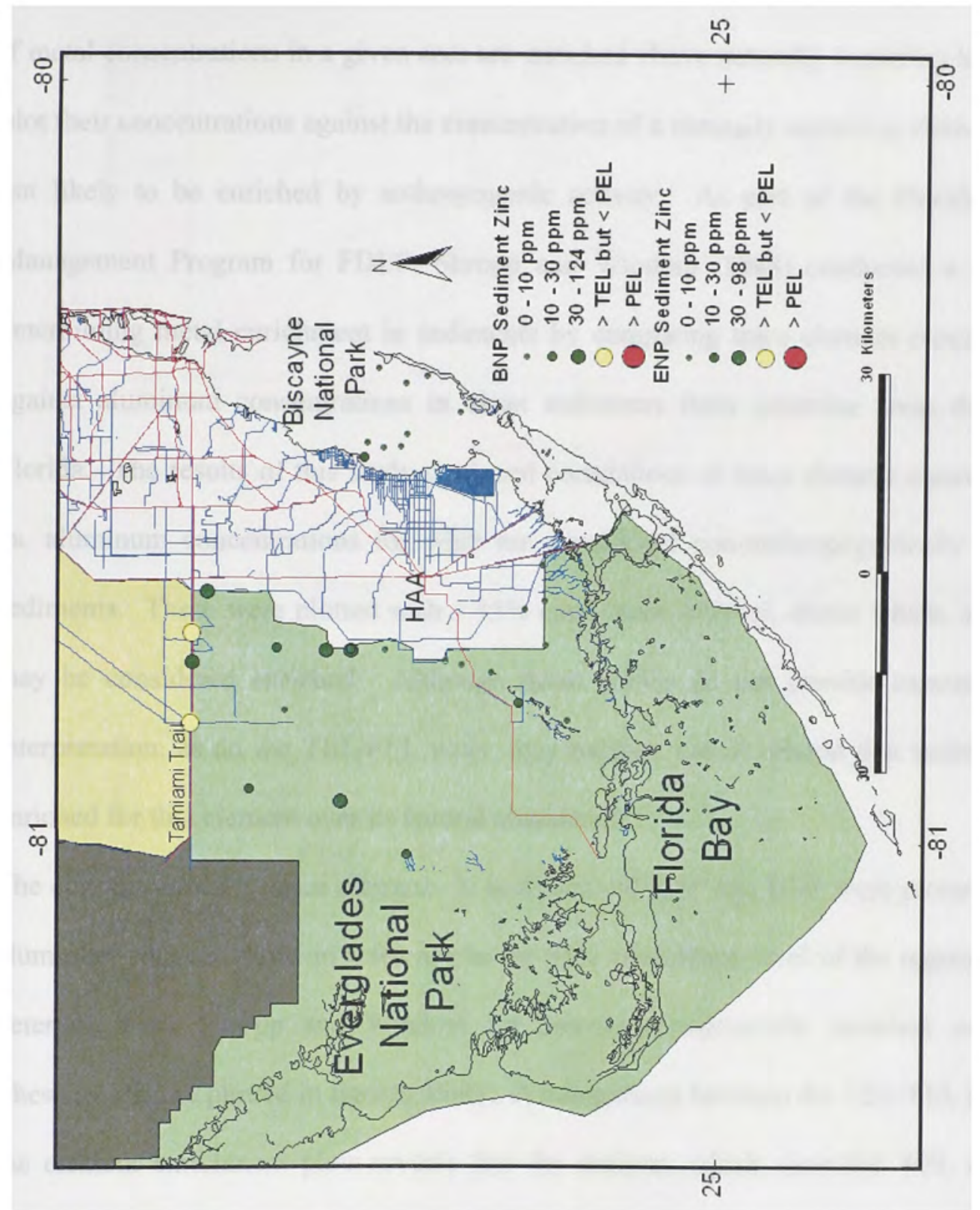

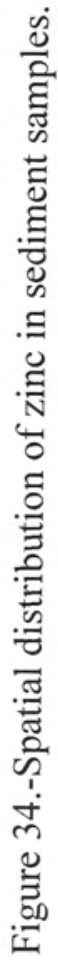


The distributions of metal concentrations in sediments vary widely within regions and are influenced by a variety of factors such as grain size, organic content and anthropogenic enrichment (Shropp and Windom, 1988). One method used to determine if metal concentrations in a given area are enriched above naturally occurring levels is to plot their concentrations against the concentration of a naturally occurring element that is not likely to be enriched by anthropogenic activity. As part of the Florida Coastal Management Program for FDEP, Shropp and Windom (1988) conducted a study for determining metal enrichment in sediments by comparing trace element concentrations against aluminum concentrations in clean sediments from estuarine areas throughout Florida. The results of this study produced correlations of trace element concentrations vs. aluminum concentrations for what are considered non-anthropogenically enriched sediments. These were plotted with a $95 \%$ confidence interval, above which, sediments may be considered enriched. Although these graphs do not provide exposure-based interpretation, as do the TEL/PEL plots, they indicate the likelihood that sediments are enriched for that element over its natural abundance.

The concentrations of trace elements in sediments of ENP and BNP were plotted against aluminum concentrations in reference to the $95 \%$ confidence level of the regression line determined by Shropp and Windom for non-anthropogenically enriched sediments. These results are plotted in figures 35-41. A comparison between the TEL/PEL plots and the element enrichment plots reveals that the stations, which exceeded TEL and PEL criteria, also fall above the $95 \%$ limit, which indicates anthropogenic enrichment. This method was applied to Biscayne Bay and Miami River 




Figure 35.-Concentrations of arsenic vs. aluminum in ENP sediments.

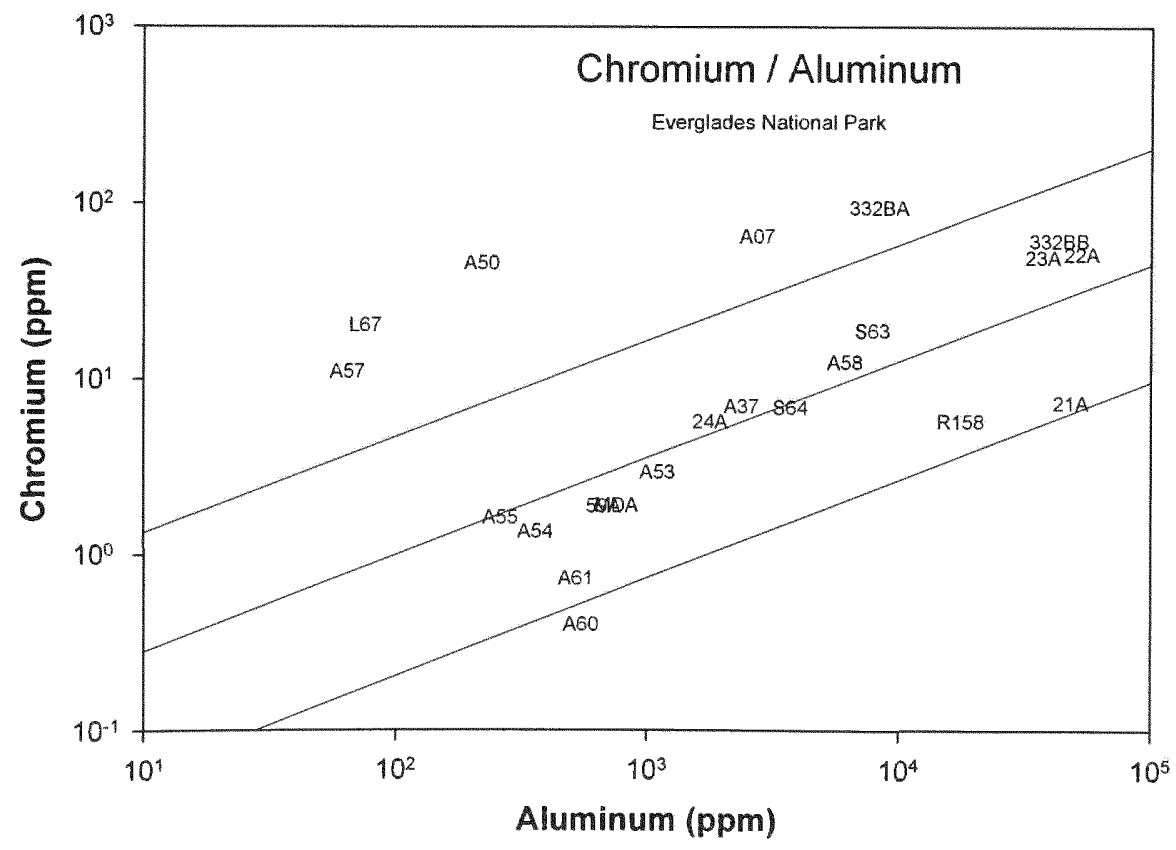

Figure 36.-Concentrations of chromium vs. aluminum in ENP sediments. 


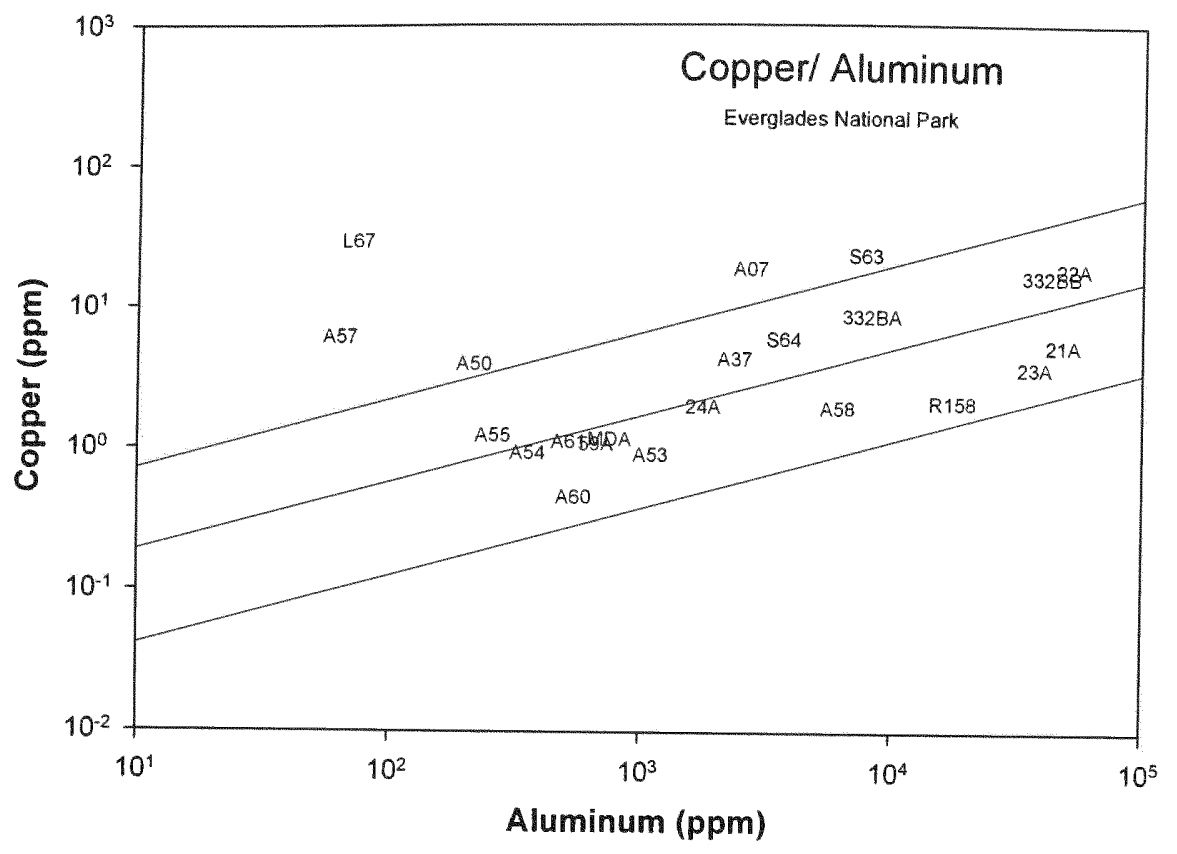

Figure 37.-Concentrations of copper vs. aluminum in ENP sediments.

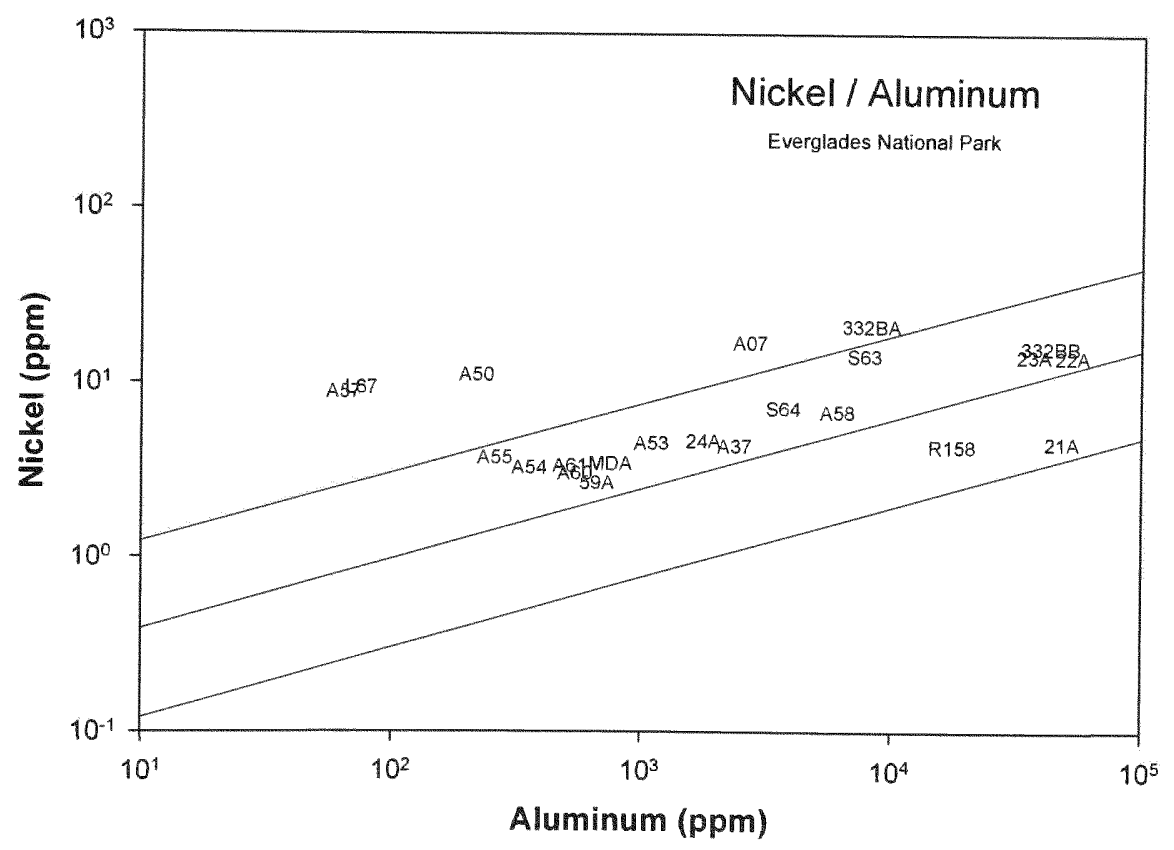

Figure 38.-Concentrations of nickel vs. aluminum in ENP sediments. 


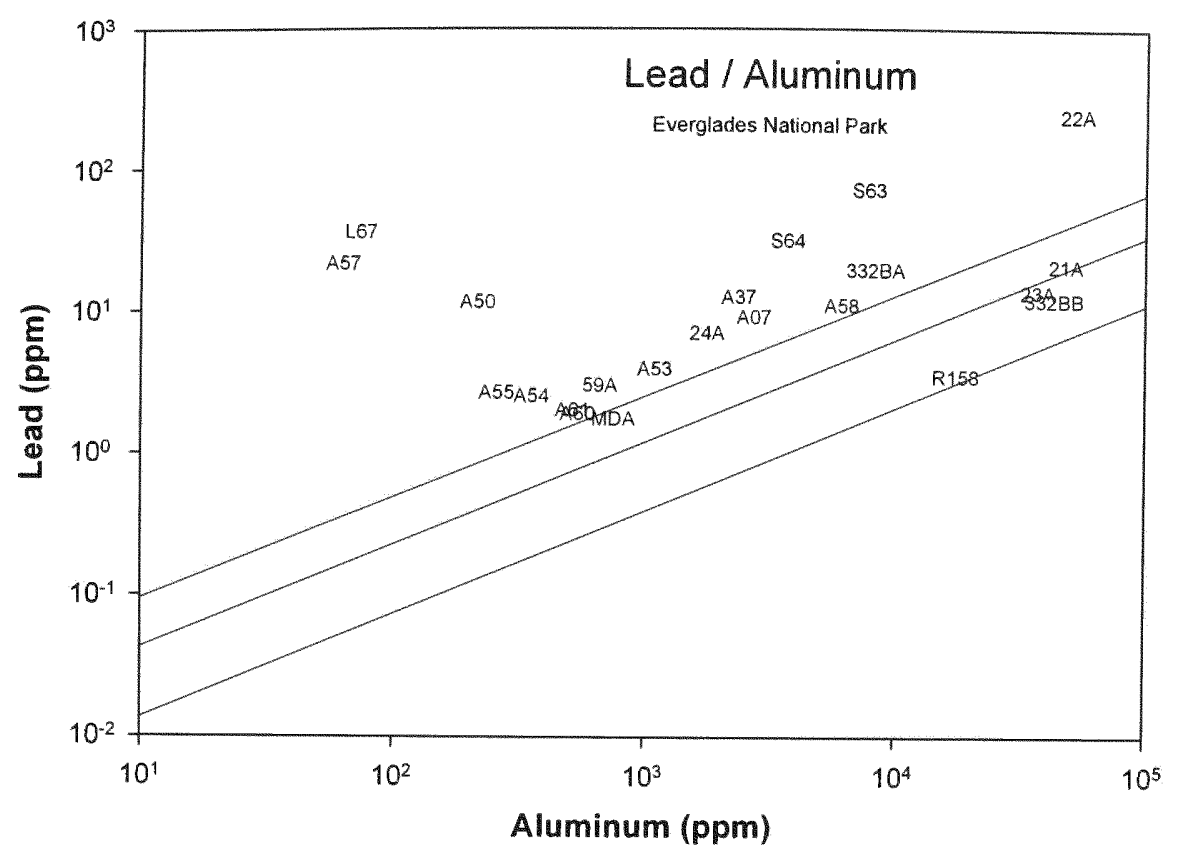

Figure 39.-Concentrations of lead vs. aluminum in ENP sediments.

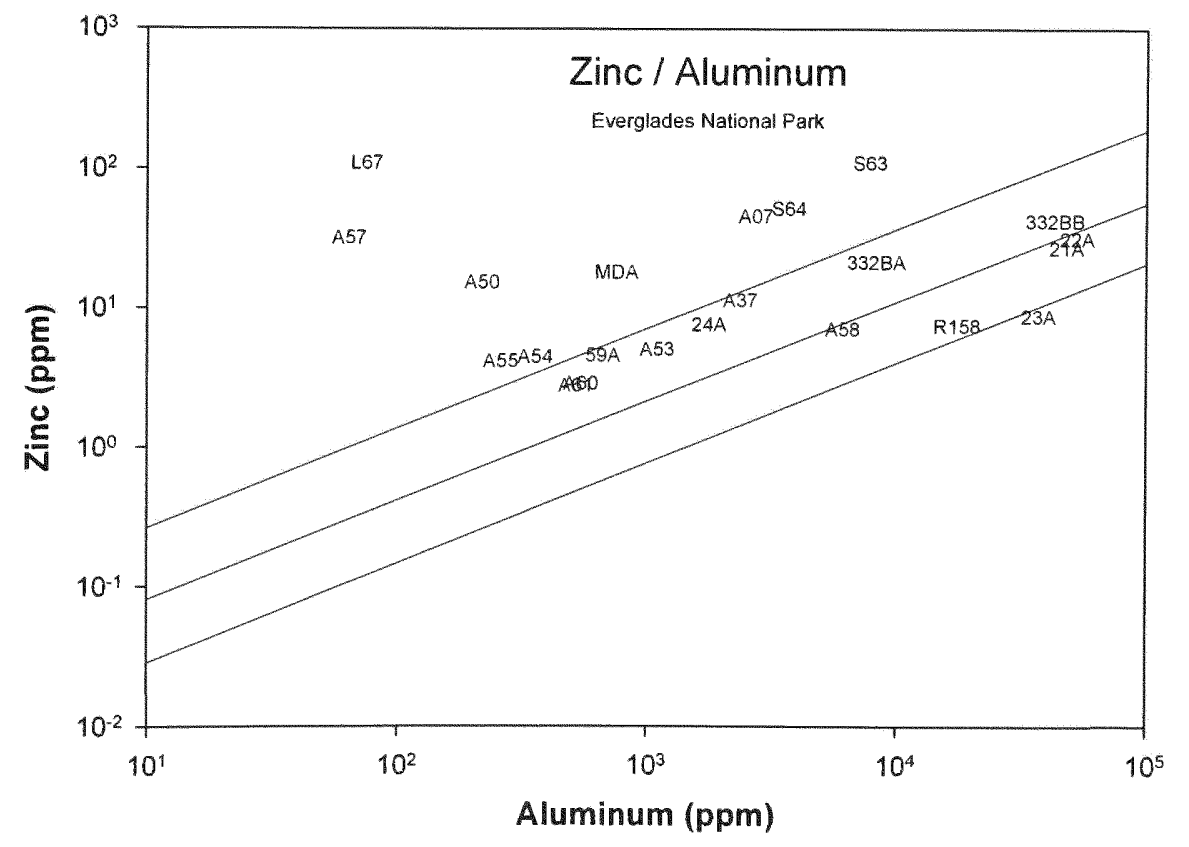

Figure 40.-Concentrations of zinc vs. aluminum in ENP sediments. 


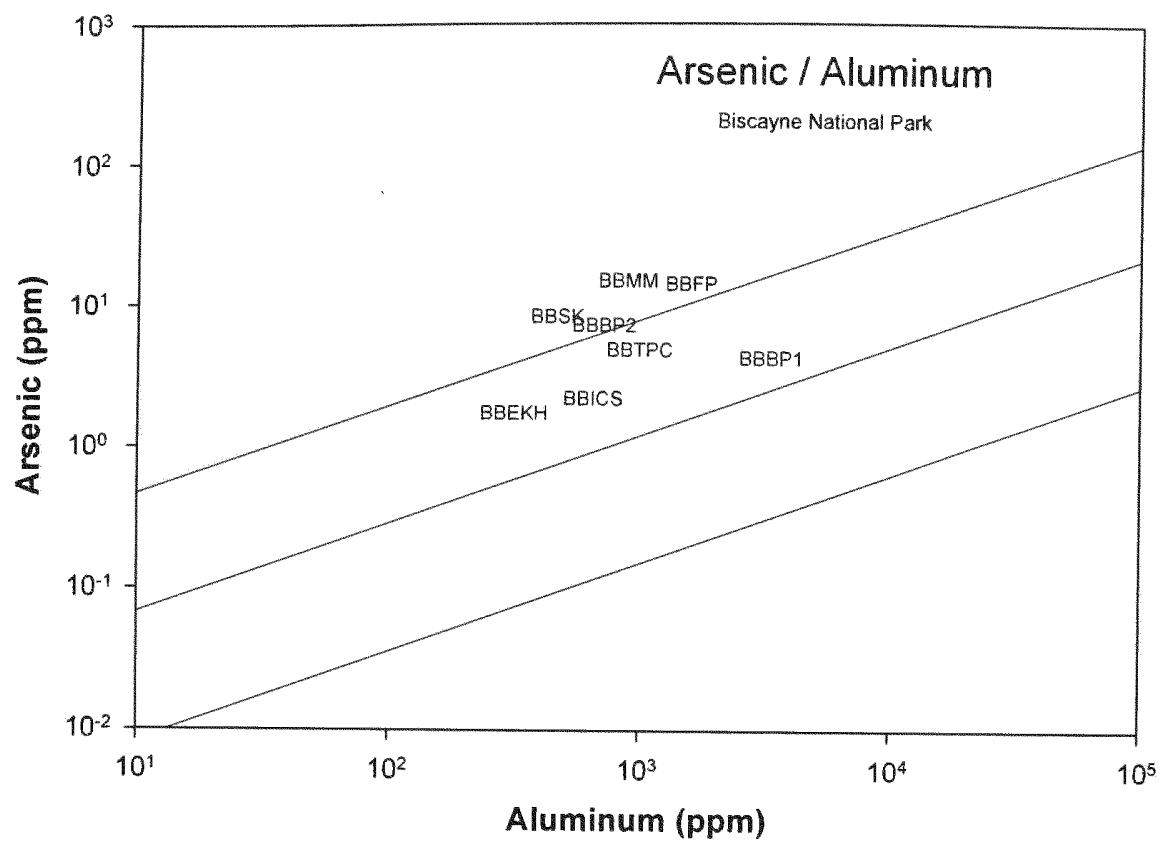

Figure 41.-Concentrations of arsenic vs. aluminum in BNP sediments.

sediments (Schropp et al. 1990) and the results revealed enrichment of cadmium, zinc, chromium, copper and lead at stations at or near the mouth of the Miami River. Although this technique was applied in this study, the results should be interpreted cautiously. Van der Weijden (2002) illustrates this using a statistical perspective as well as realistic scenarios. Specifically he describes how this method for normalization excludes realistic estimates of sedimentary phases such as organic matter, which consequently, comprises a very large fraction of the samples analyzed in this study. Furthermore, the application of Shropp's correlations is better suited to areas that have a consistent source for aluminum such as clays, which are not present in the sediments analyzed in this study. 
Some trends are apparent in the distribution of trace elements among the different regions of the study area. Figures $42-50$ show box plot graphs comparing the distribution of trace element concentrations with in the study area. These graphs indicate that the highest concentrations of beryllium, vanadium, and chromium are found in the Eastern Boundary and Shark Slough areas, while Cobalt and Nickel are highest in the Eastern Boundary, Shark Slough, and Tamiami areas. Copper, zinc, arsenic and lead all have higher concentrations in the Eastern Boundary and the Tamiami areas.

Although in many cases the variability in metal content for the different regions was not very large, it seems that the ENP East Boundary and Tamiami Trail regions suffer the greatest trace metal impacts, although, as in the case of the organochlorine compounds, Shark Slough also seems to act as a sink for trace metals.

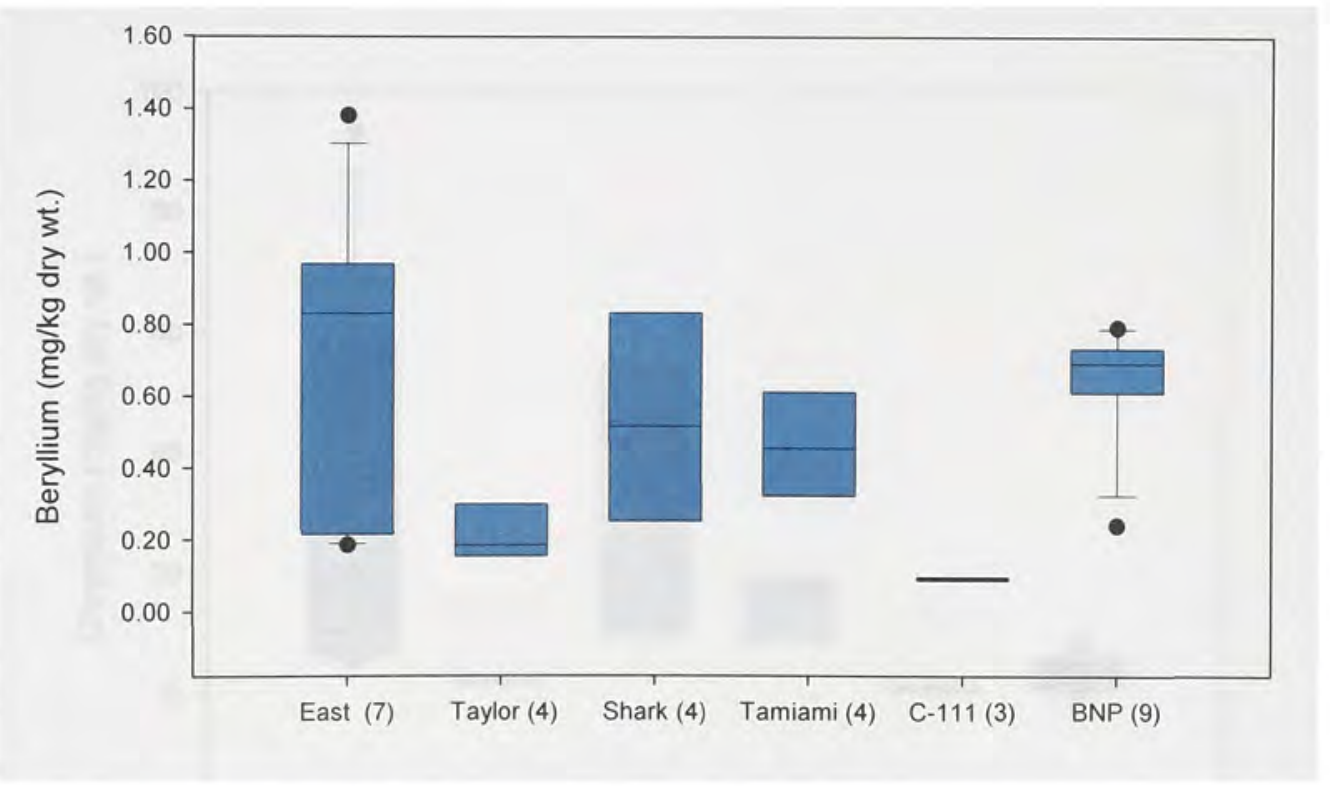

Figure 42.-Distribution of Beryllium in sediments within study area. 


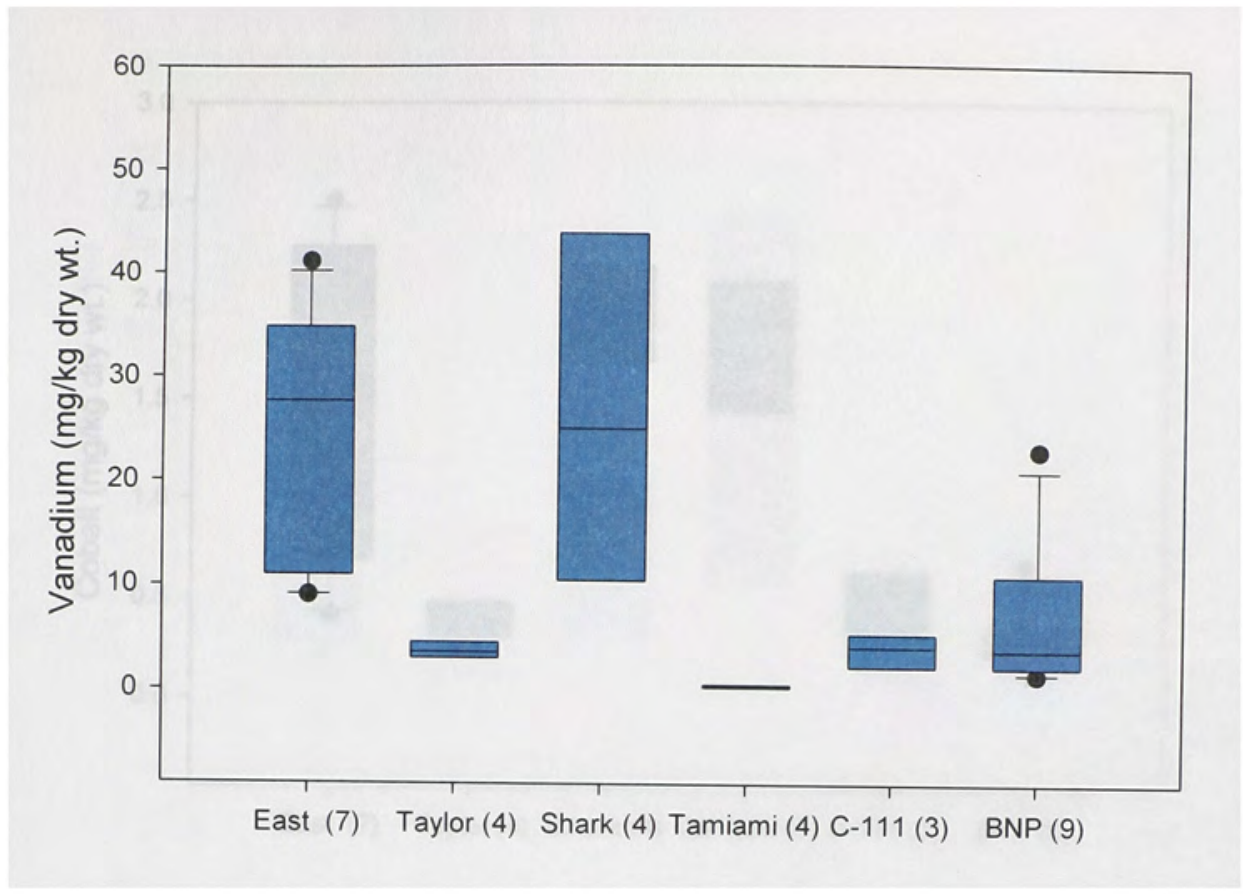

Figure 43.-Distribution of Vanadium in sediments within study area.

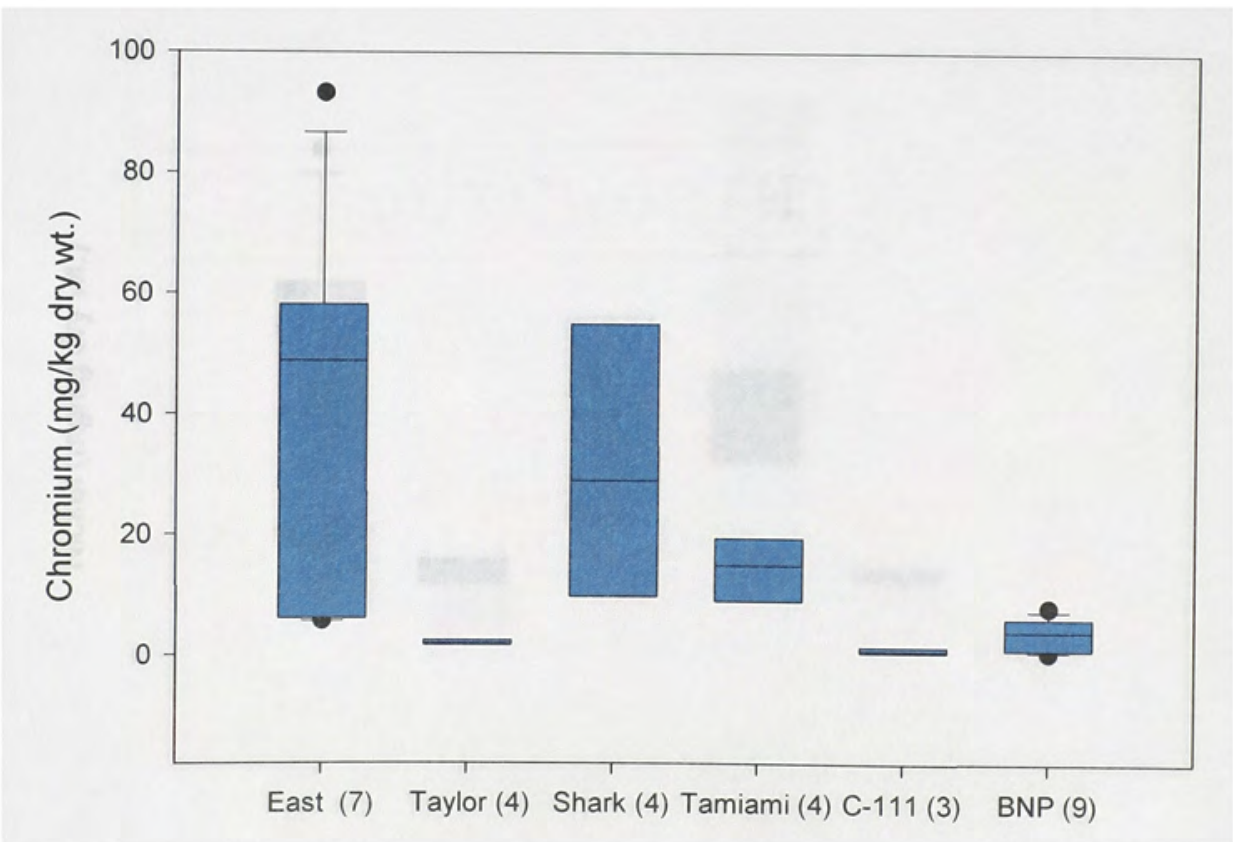

Figure 44.-Distribution of Chromium in sediments within study area. 


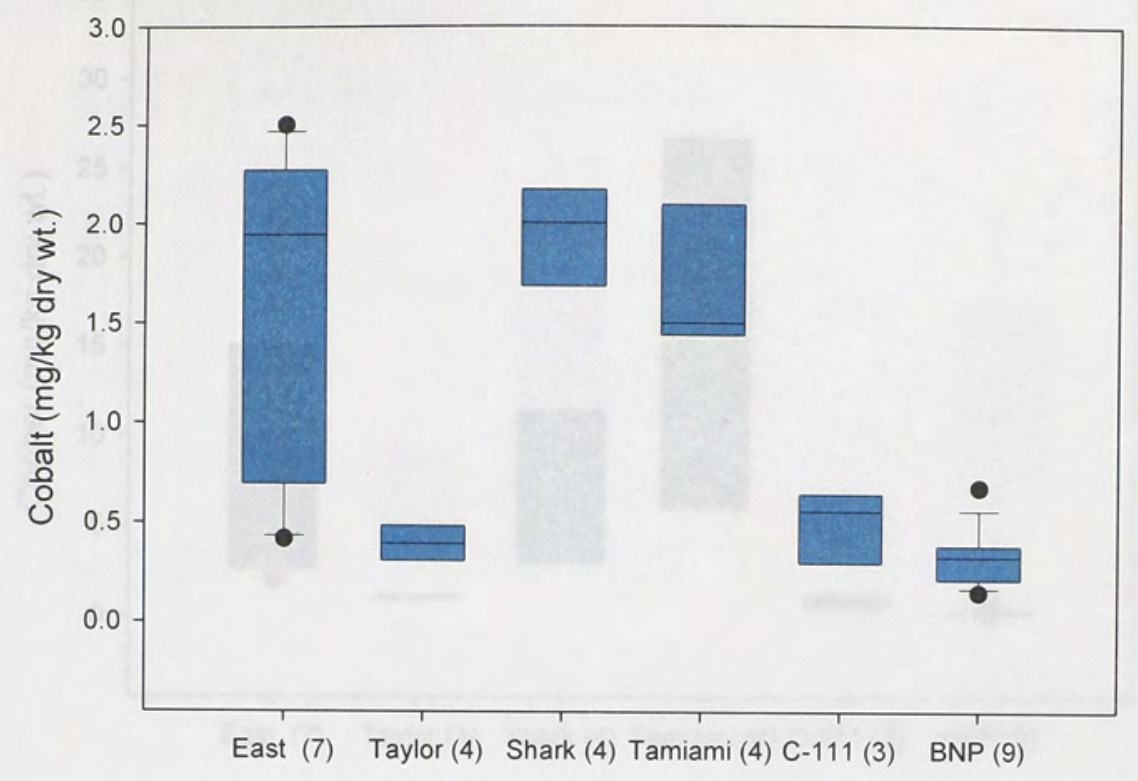

Figure 45.-Distribution of Cobalt in sediments within study area.

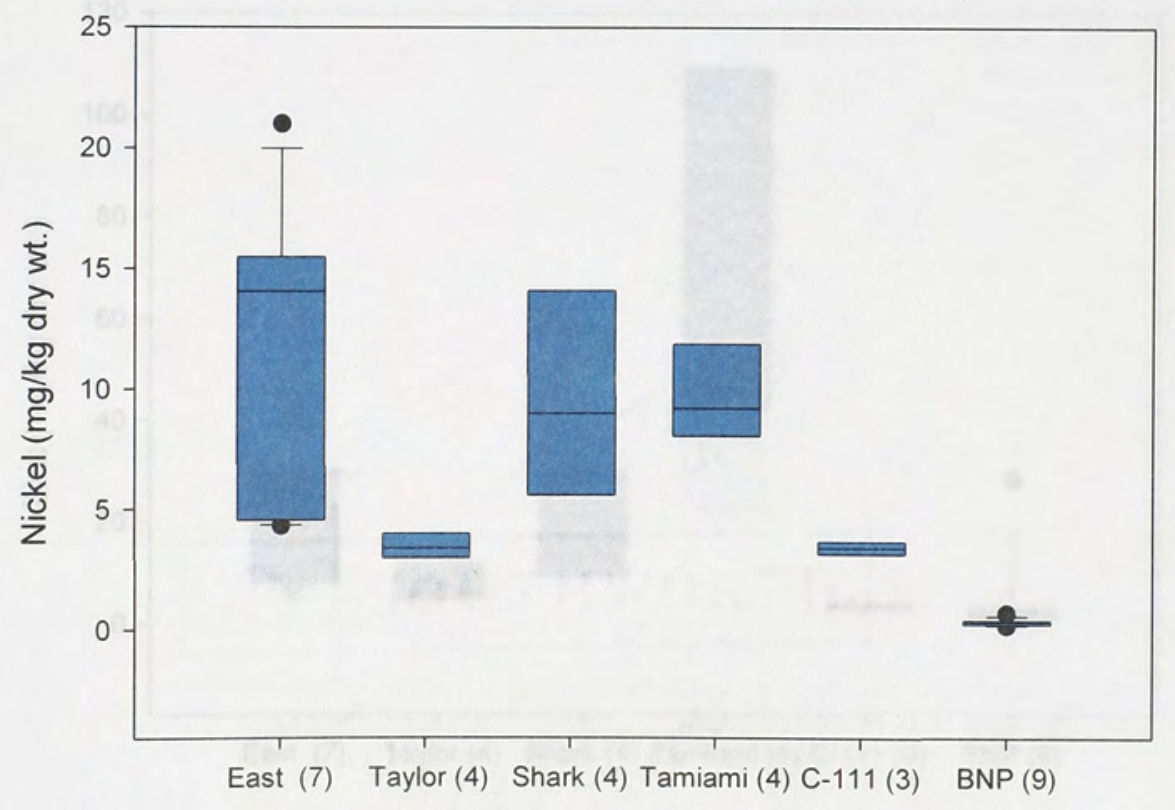

Figure 46.-Distribution of Nickel in sediments within study area. 


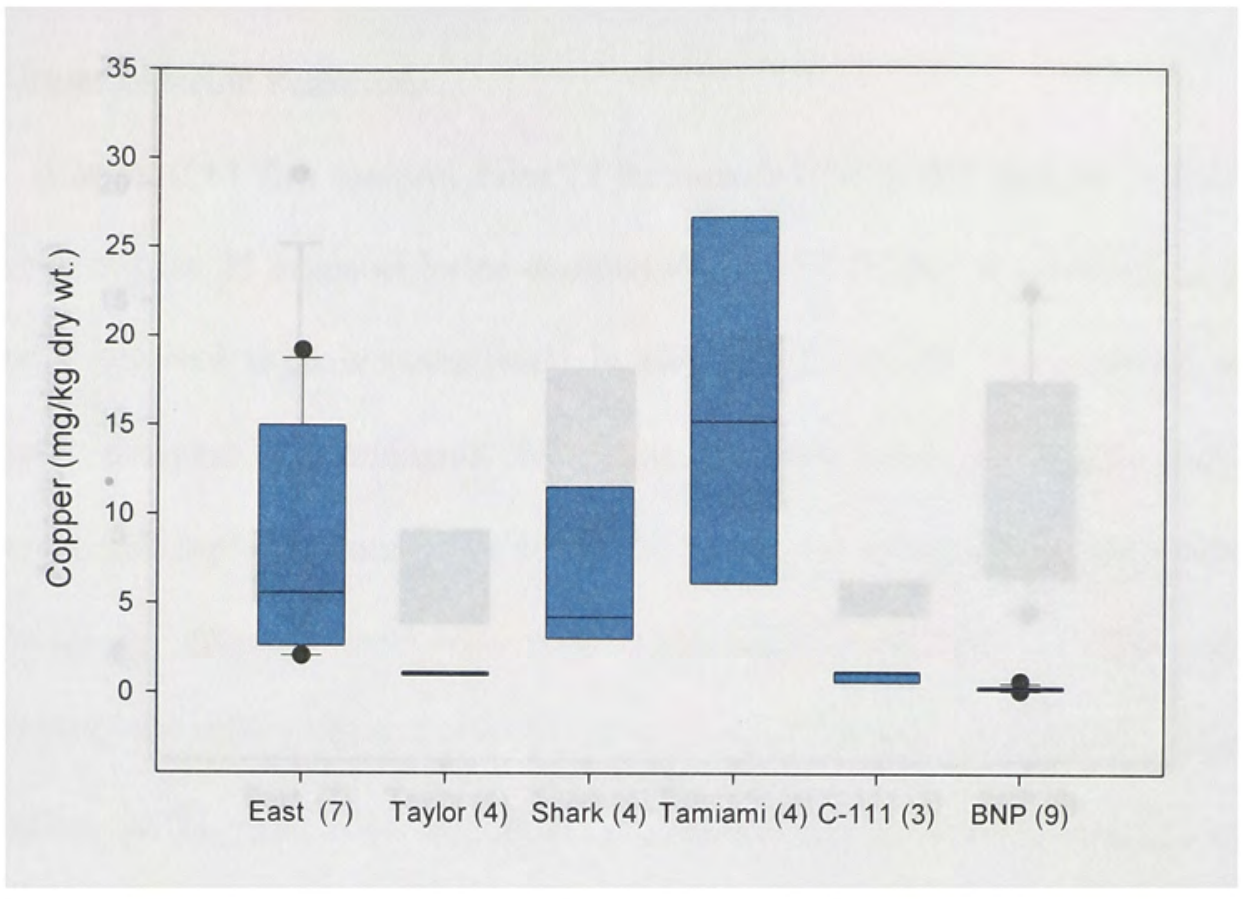

Figure 47.-Distribution of Copper in sediments within study area.

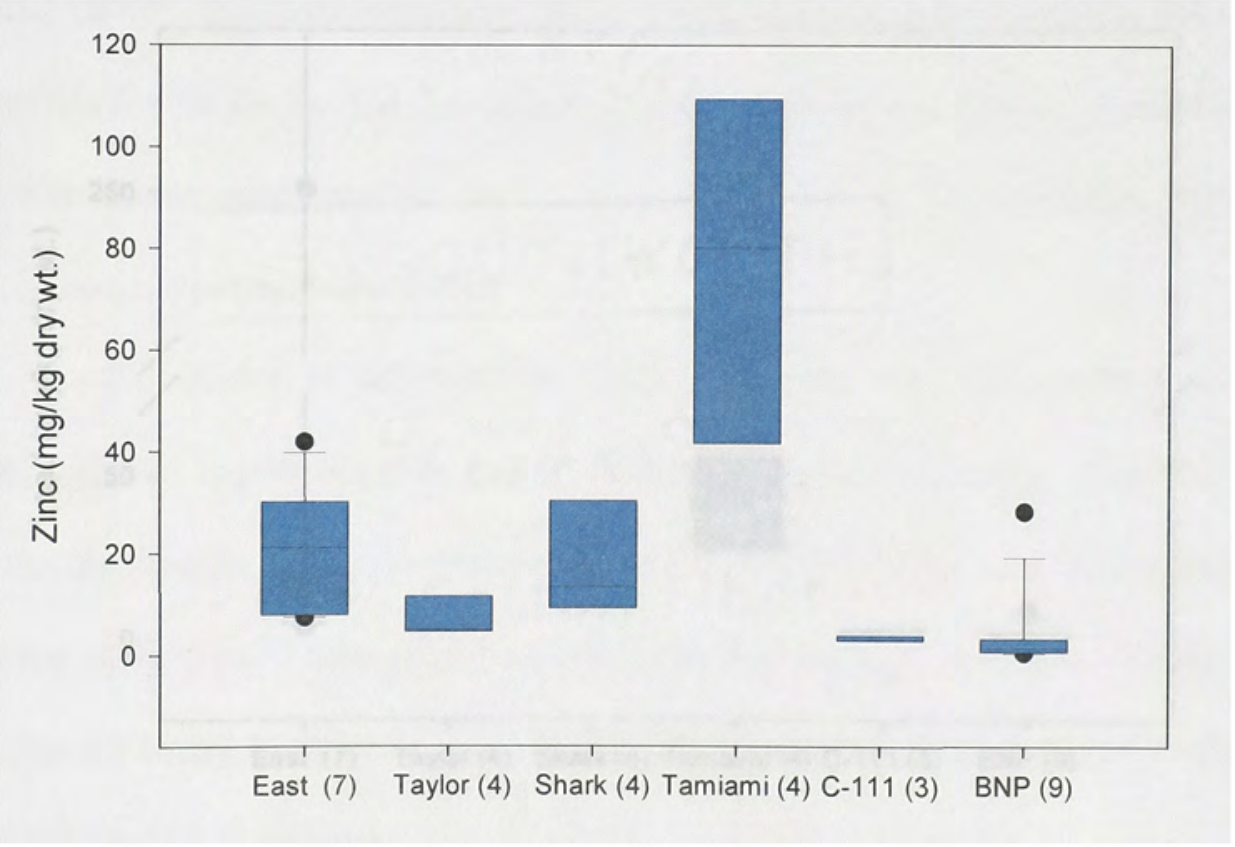

Figure 48.-Distribution of Zinc in sediments within study area. 


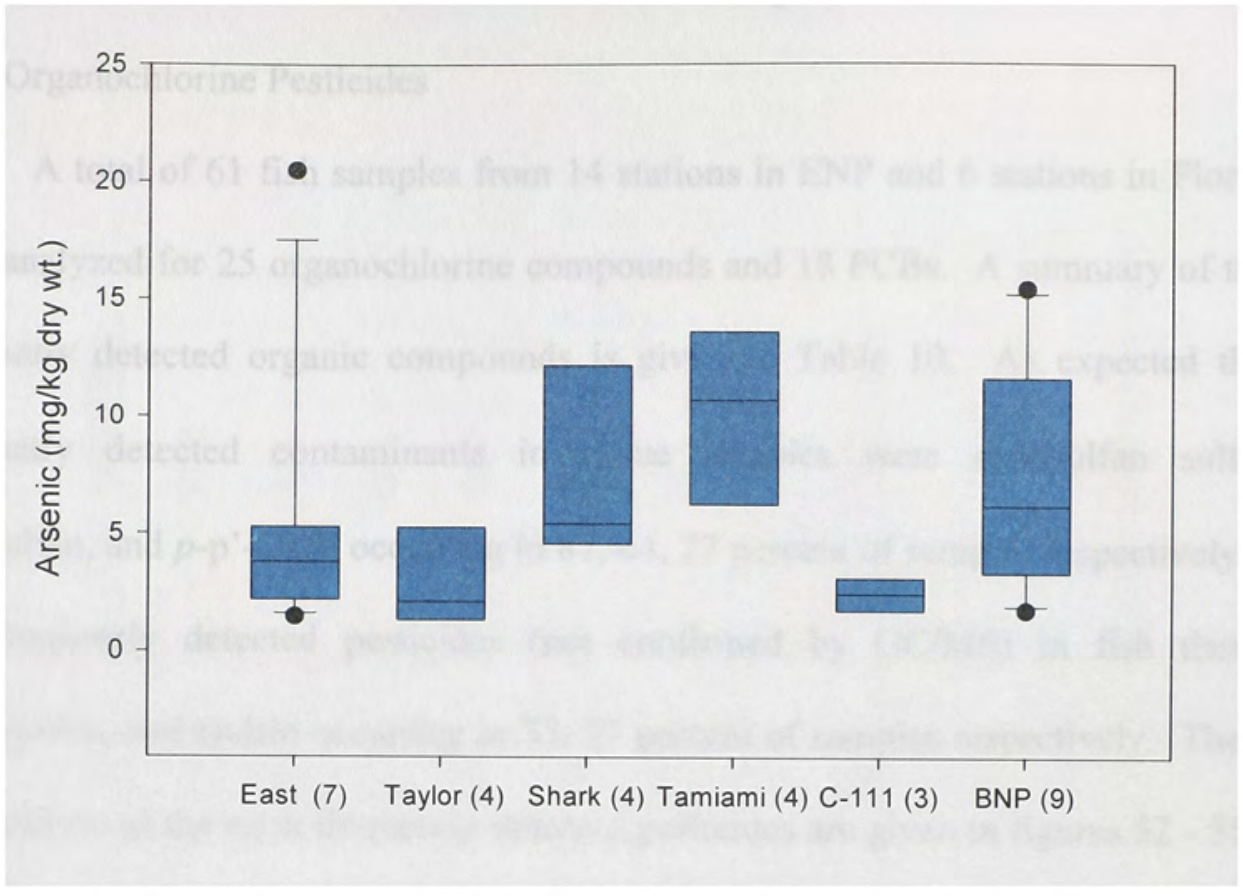

Figure 49.-Distribution of Arsenic in sediments within study area.

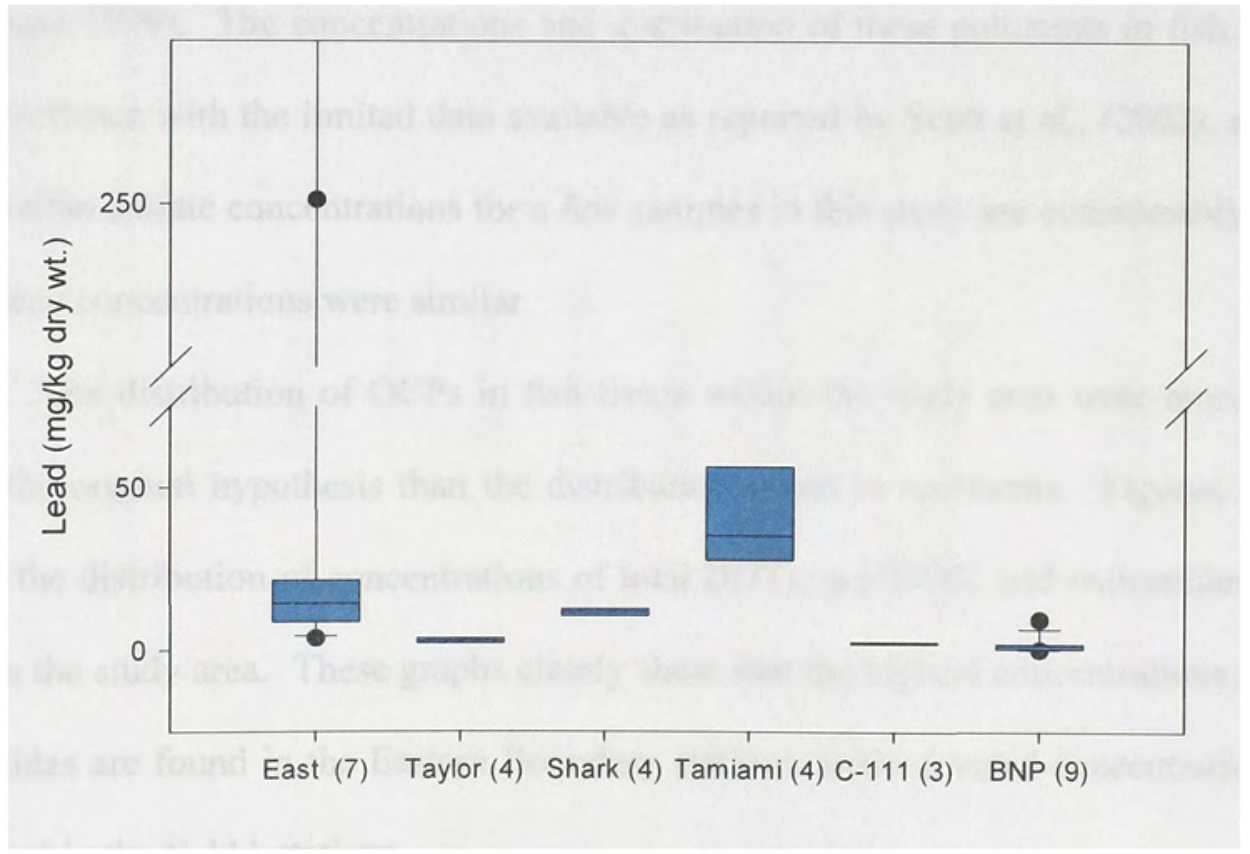

Figure 50.-Distribution of Lead in sediments within study area. 


\subsection{Organic Contaminants in Whole Fish Tissue Samples}

\subsubsection{Organochlorine Pesticides}

A total of 61 fish samples from 14 stations in ENP and 6 stations in Florida Bay were analyzed for 25 organochlorine compounds and 18 PCBs. A summary of the most frequently detected organic compounds is given in Table 10. As expected the most frequently detected contaminants in tissue samples were endosulfan sulfate, $\beta$ endosulfan, and $p$-p'-DDE occurring in $87,64,77$ percent of samples respectively. Other less frequently detected pesticides (not confirmed by GC/MS) in fish tissues are chlorpyrifos, and endrin occurring in 55, 27 percent of samples respectively. The spatial distributions of the most frequently detected pesticides are given in figures $52-55$. Here as well, a trend is apparent with the highest body burdens occurring at those stations closest to the HAA where the application of endosulfan and chlorpyrifos is still occurring (Shahane 1999). The concentrations and distribution of these pollutants in fish tissue is in accordance with the limited data available as reported by Scott et al., (2002), although endosulfan sulfate concentrations for a few samples in this study are considerably higher, the mean concentrations were similar.

The distribution of OCPs in fish tissue within the study area were more in line with the original hypothesis than the distribution found in sediments. Figures $56-58$ show the distribution of concentrations of total DDTs, p-p'DDE, and endosulfan sulfate within the study area. These graphs clearly show that the highest concentrations of these pesticides are found in the Eastern Boundary stations, with elevated concentrations also detected in the $\mathrm{C}-111$ stations. 


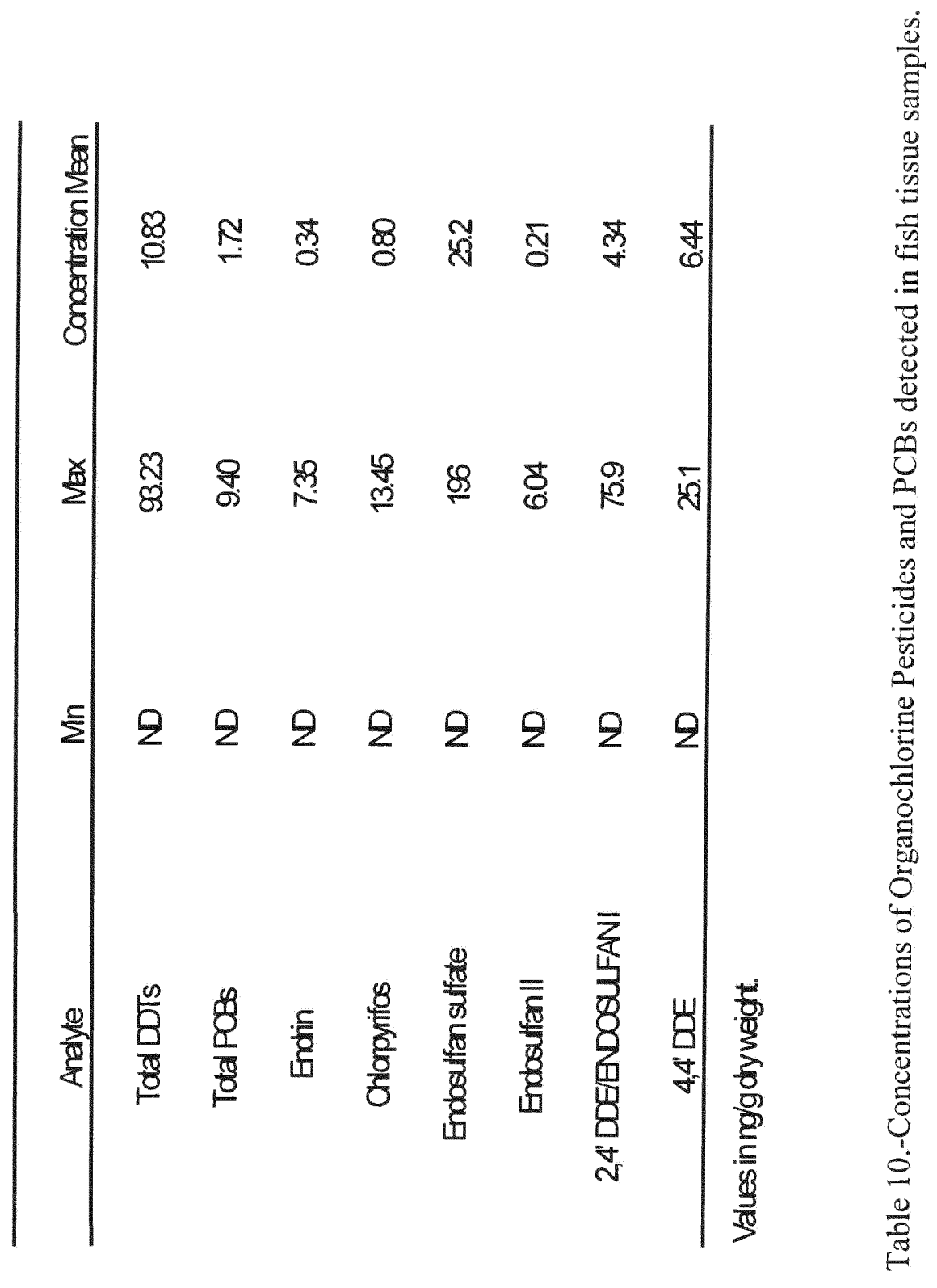




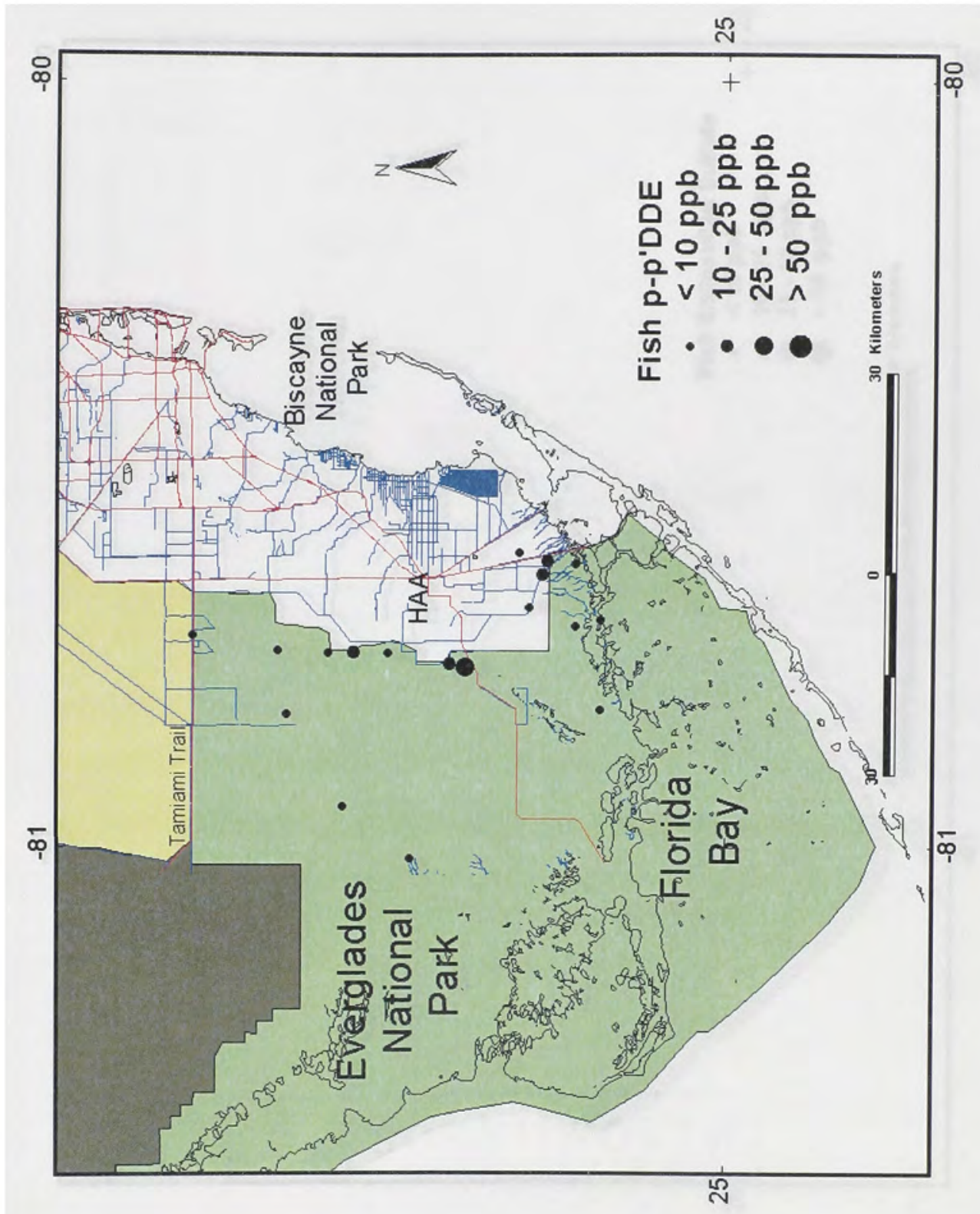

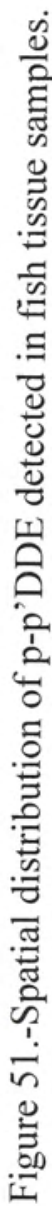




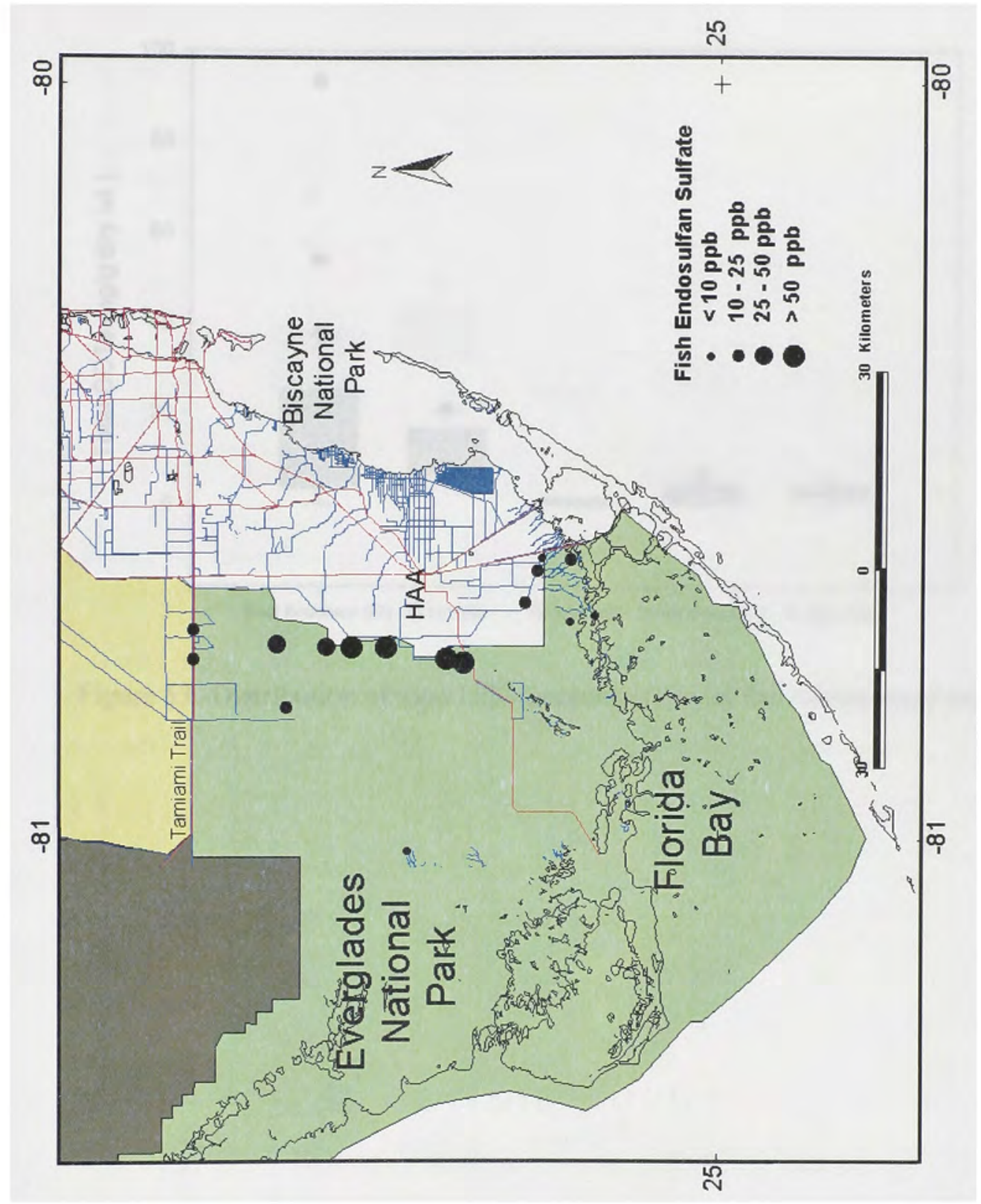

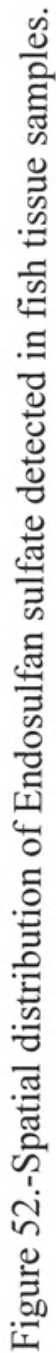




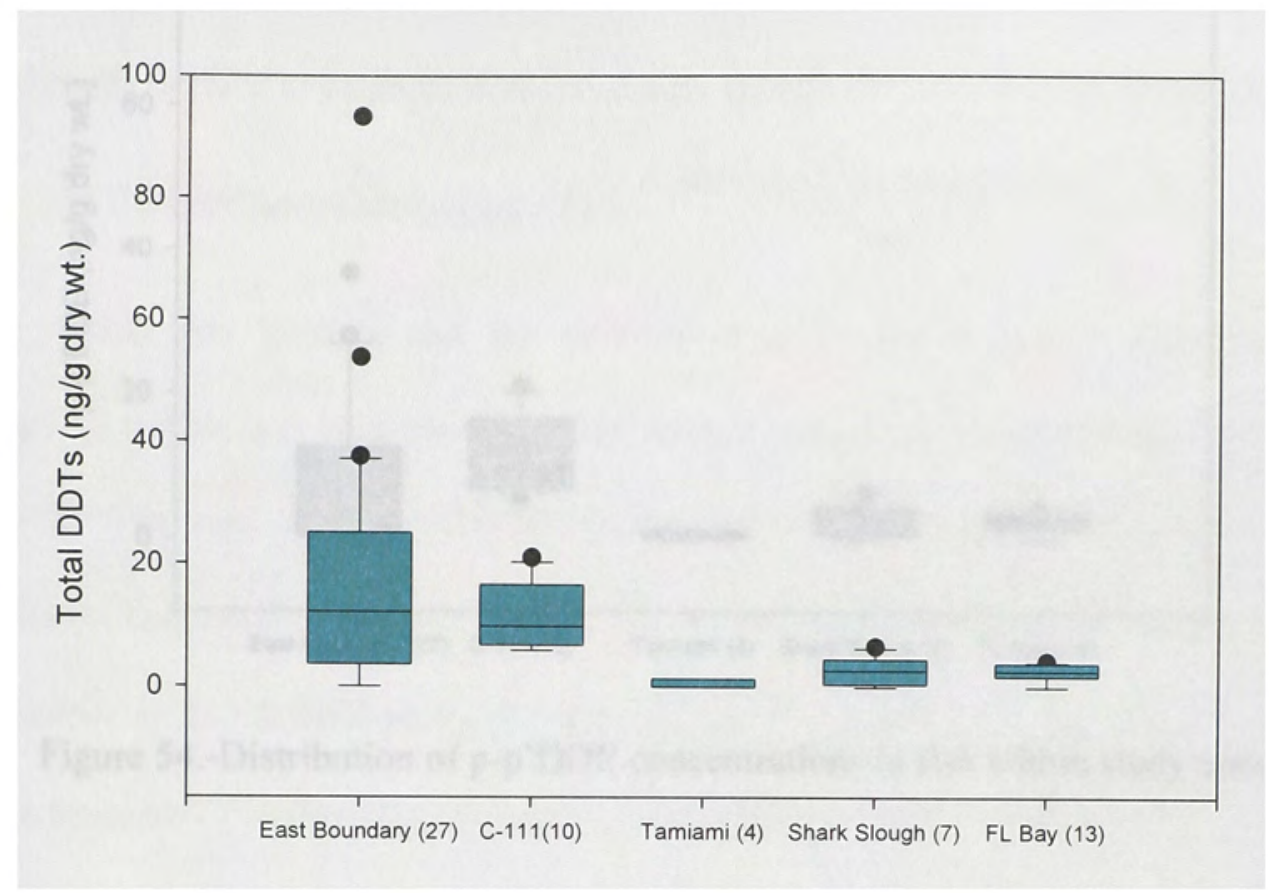

Figure 53.-Distribution of total DDT concentrations in fish within study area. 


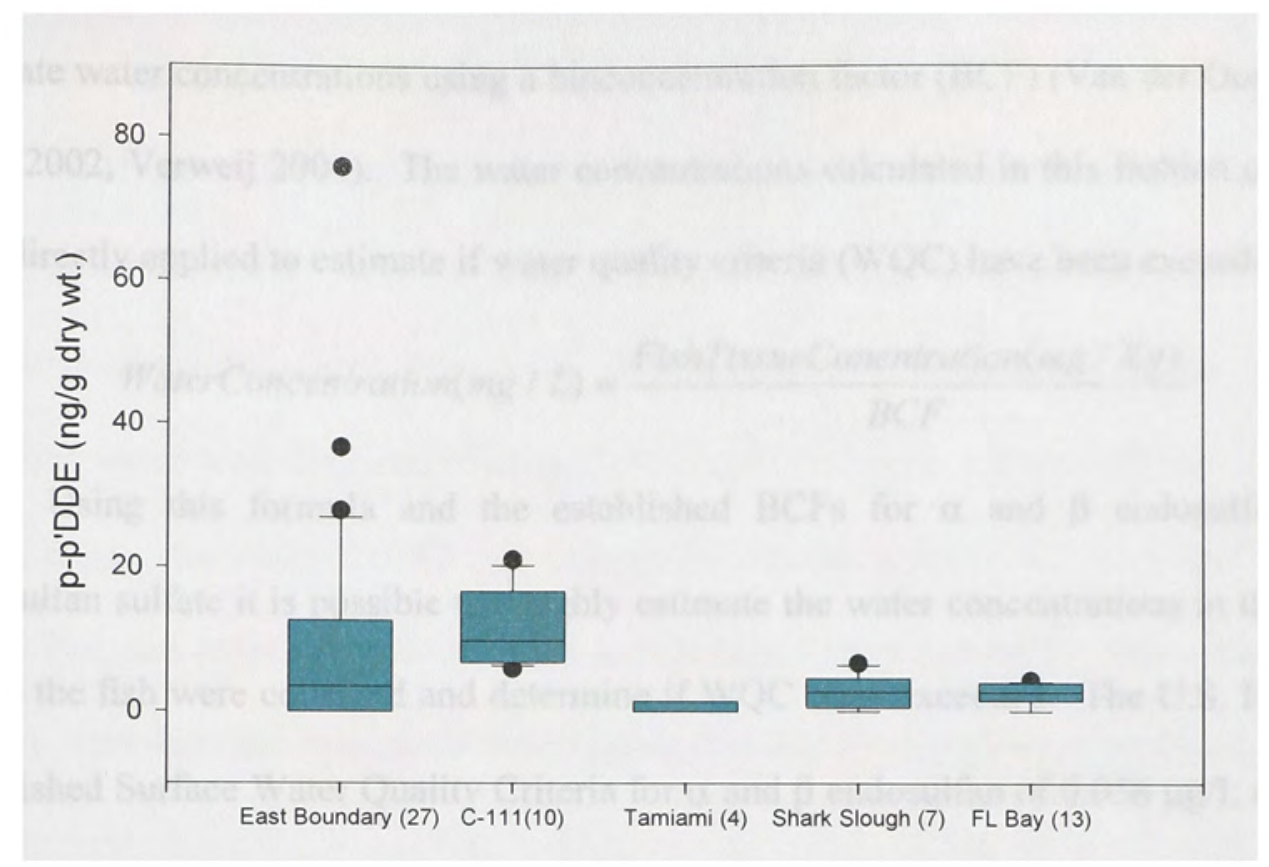

Figure 54.-Distribution of p-p'DDE concentrations in fish within study area.

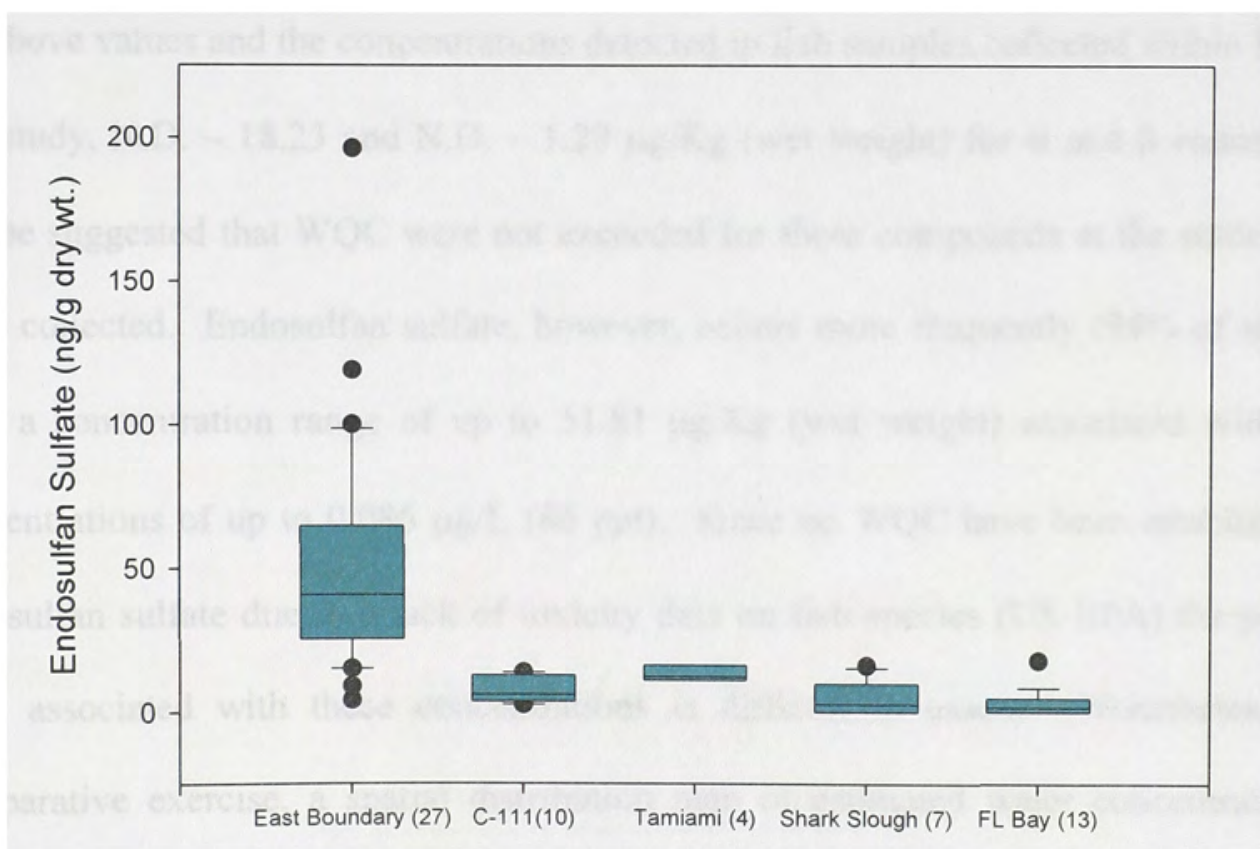

Figure 55.-Distribution of Endosulfan Sulfate concentrations in fish within study area. 
It is well documented that fish tissue concentrations (FTCs) can be used to estimate water concentrations using a bioconcentration factor (BCF) (Van der Oost 2003, Scott 2002, Verweij 2004). The water concentrations calculated in this fashion can then be indirectly applied to estimate if water quality criteria (WQC) have been exceeded.

$$
\text { WaterConcentration }(m g / L)=\frac{\text { FishTissueConentration }(m g / K g)}{B C F}
$$

Using this formula and the established BCFs for $\alpha$ and $\beta$ endosulfan, and endosulfan sulfate it is possible to roughly estimate the water concentrations in the areas where the fish were collected and determine if WQC were exceeded. The U.S. EPA has established Surface Water Quality Criteria for $\alpha$ and $\beta$ endosulfan of $0.056 \mu \mathrm{g} / \mathrm{L}$ ( $56 \mathrm{ppt}$ ) for freshwater and $0.0087 \mu \mathrm{g} / \mathrm{L}(8.7 \mathrm{ppt})$ for marine waters, and has established $\mathrm{BCF}$ values for $\alpha$ and $\beta$ endosulfan, and endosulfan sulfate of 600 (ATSDR 1991). Based on the above values and the concentrations detected in fish samples collected within ENP for this study, N.D. -18.23 and N.D. $-1.29 \mu \mathrm{g} / \mathrm{Kg}$ (wet weight) for $\alpha$ and $\beta$ endosulfan it can be suggested that WQC were not exceeded for these compounds at the stations they were collected. Endosulfan sulfate, however, occurs more frequently ( $94 \%$ of samples) with a concentration range of up to $51.81 \mu \mathrm{g} / \mathrm{Kg}$ (wet weight) associated with water concentrations of up to $0.086 \mu \mathrm{g} / \mathrm{L}(86 \mathrm{ppt})$. Since no WQC have been established for endosulfan sulfate due to a lack of toxicity data on fish species (US EPA) the potential risks associated with these concentrations is difficult to assess. Nonetheless, as a comparative exercise, a spatial distribution map of estimated water concentrations of endosulfan sulfate based on tissue residue concentrations is given in figure 55. It must be 
noted however, that the water quality criteria expressed in the figure are for $\alpha$ and $\beta$ endosulfan, not endosulfan sulfate.

Analysis of fish samples collected from Florida Bay did not reveal the presence of $\alpha$ or $\beta$ endosulfan. Endosulfan sulfate, on the other hand occurred in $54 \%$ of the samples with concentrations ranging from N.D. $-5.82 \mu \mathrm{g} / \mathrm{Kg}$ (wet weight) which correspond to estimated water concentrations of up to $0.0097 \mu \mathrm{g} / \mathrm{L}(9.7 \mathrm{ppt})$, with one station, Highway Creek barely exceeding the $8.7 \mathrm{ppt}$ criteria for marine waters. NOAAs S\&T Mussel Watch Program reports that three of the five highest concentrations for endosulfan in the country were detected in mussels from Florida Bay and Rookery Bay (Cantillo A.Y. et al. 1997) 


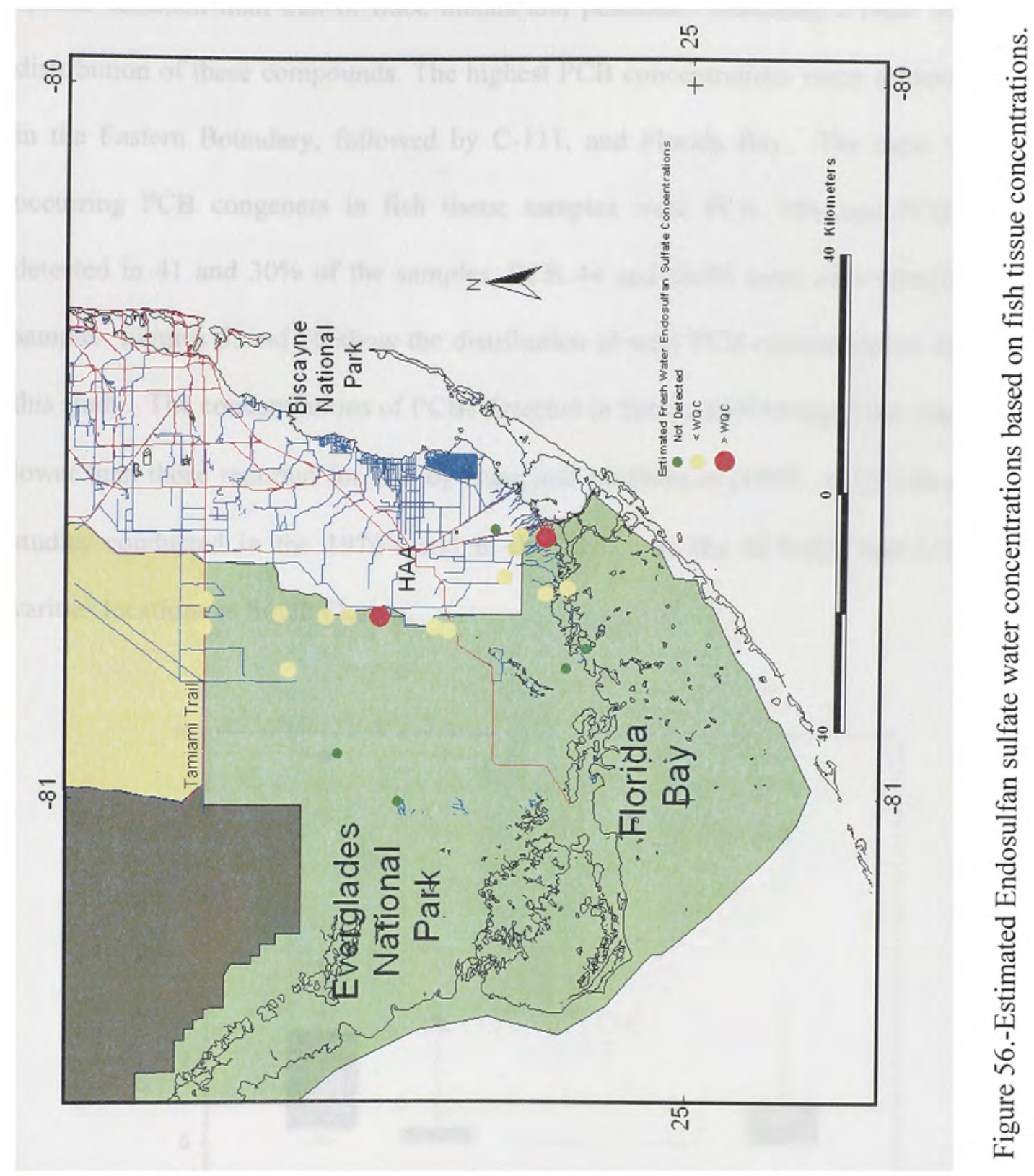




\subsubsection{Polychlorinated Biphenyls}

The concentrations of PCBs were generally low and their distributions show less spatial variation than that of trace metals and pesticides indicating a more widespread distribution of these compounds. The highest PCB concentrations occur at those stations in the Eastern Boundary, followed by C-111, and Florida Bay. The most frequently occurring PCB congeners in fish tissue samples were PCB 180, and PCB 138/160 detected in 41 and $30 \%$ of the samples, PCB 44 and 66/95 were each detected in one sample. Figures 55 and 56 show the distribution of total PCB concentrations detected in this study. The concentrations of PCBs detected in fish (1.85-9.40 ng/g) are considerably lower than those reported for fish by Haag and McPherson (1997), $(<50-140 \mu \mathrm{g} / \mathrm{kg})$ in studies conducted in the 1970's and in the 1990's by the SFWMD and U.S.G.S. in various locations in South Florida.

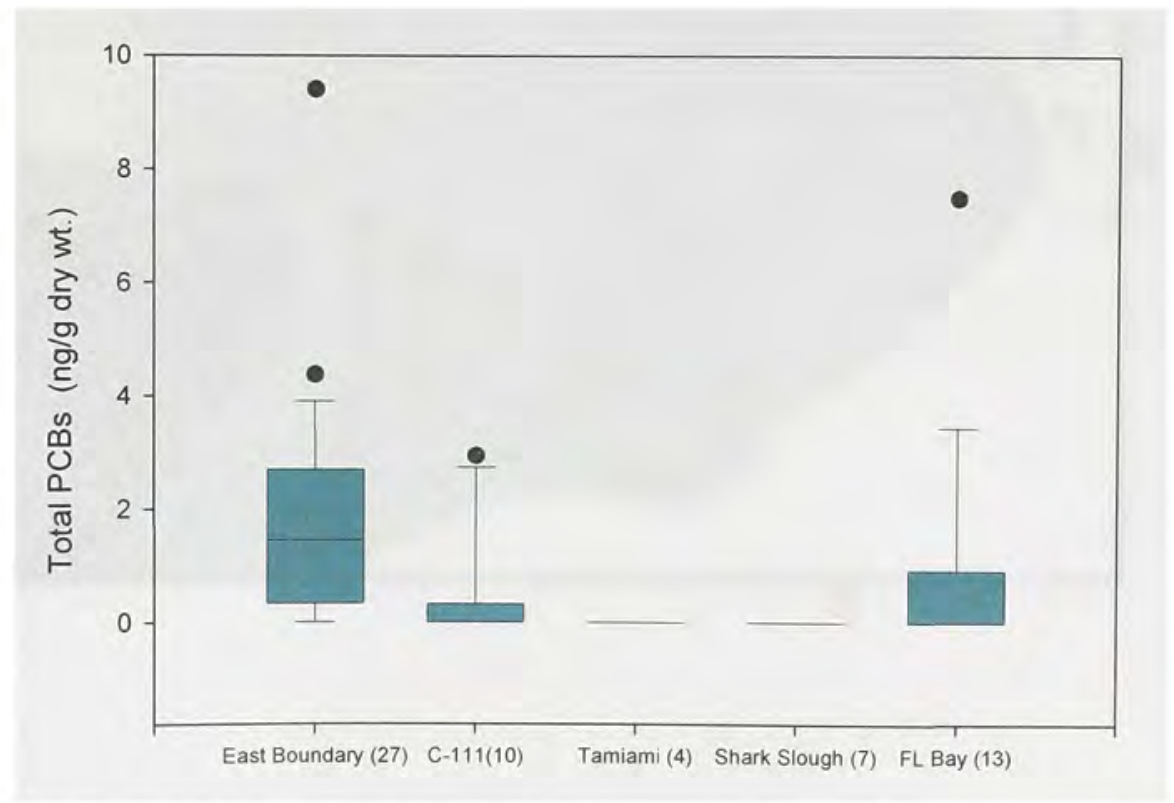

Figure 57.- Distribution of Total PCB concentrations in fish within study area. 


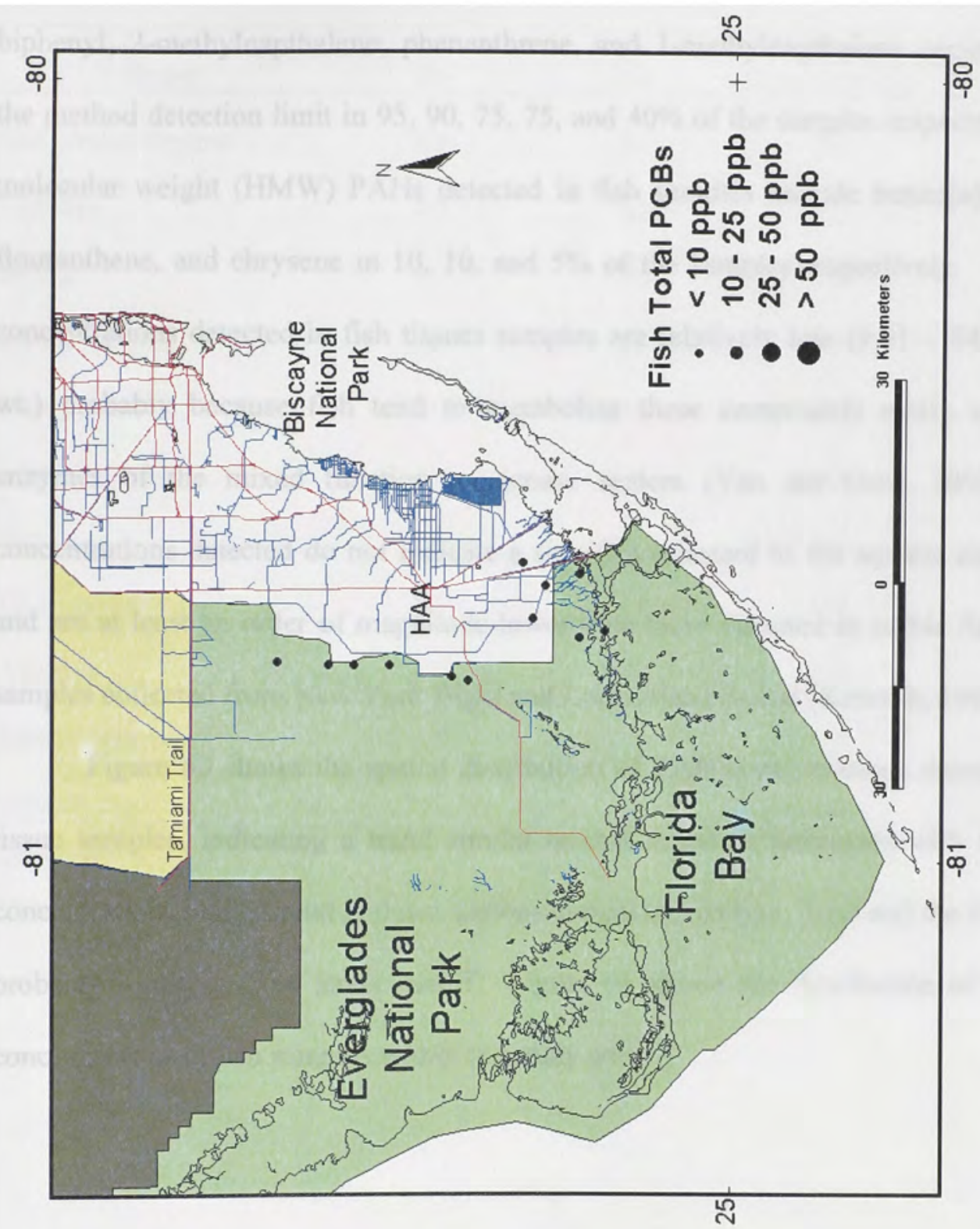

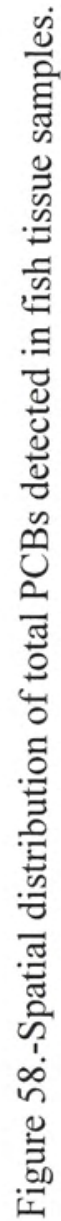




\subsubsection{Polycyclic Aromatic Hydrocarbons}

A summary of frequently detected PAHs in fish tissues is given in table 11. PAHs detected in fish include low molecular weight (LMW) PAHs such as naphthalene, biphenyl, 2-methylnapthalene, phenanthrene, and 1-methylnapthalene occurring above the method detection limit in $95,90,75,75$, and $40 \%$ of the samples respectively. High molecular weight (HMW) PAHs detected in fish samples include benzo[a]anthracene, flouranthene, and chrysene in 10,10, and 5\% of the samples respectively. Total PAH concentrations detected in fish tissues samples are relatively low $(9.01-84.8 \mathrm{ng} / \mathrm{g}$ dry wt.) probably because fish tend to metabolize these compounds easily via phase I enzymes of the mixed function oxygenase system (Van der Oost, 2003). These concentrations detected do not indicate a significant hazard to the aquatic environment, and are at least an order of magnitude lower than those detected in edible fish tissue in samples collected from New York Bight and Long Island Sound (Kennish, 1997).

Figure 60 shows the spatial distribution of PAH concentrations detected in fish tissue samples, indicating a trend similar to that found in sediments with the highest concentrations being found at those stations closest to Tamiami Trail and the HAA again, probably resulting from street runoff. Figure 61 shows the distribution of total PAH concentrations in fish samples within the study area. 
Table 11.-Concentrations of frequently detected PAHs in fish tissue samples.

\begin{tabular}{|c|c|c|c|c|}
\hline Analyte & $\mathrm{Mn}$ & Max & Concentration Mean & $>M a^{a}$ \\
\hline Tdta PAHswith Perylene & 9.01 & 85 & 269 & \\
\hline Napthelene & $N$ & 15.9 & 7.91 & $95 \%$ \\
\hline Bpheny & $N$ & 17.9 & 4.41 & $90 \%$ \\
\hline 2Mthyiradthedene & $N$ & 8.33 & 349 & $75 \%$ \\
\hline Pheneattrene & $N$ & 31.2 & 6.12 & $75 \%$ \\
\hline 1-Methyingathdene & $\mathrm{ND}$ & 4.67 & 1.43 & $40 \%$ \\
\hline Fuarene & $N$ & 10.0 & 203 & $25 \%$ \\
\hline C2-Napthelene & $N$ & 124 & 8.24 & $20 \%$ \\
\hline Antracene & $N$ & 7.02 & 3.12 & $10 \%$ \\
\hline Berzo[a/Anthraoene & $N$ & 15.7 & 4.09 & $10 \%$ \\
\hline Anysene & $\mathrm{ND}$ & 212 & 1.10 & $5 \%$ \\
\hline
\end{tabular}

Valuesinnglg dy weight.

${ }^{a}$ Percentage of toda samples $(N=20)$ above method datedion limit ( $(M C)$. 


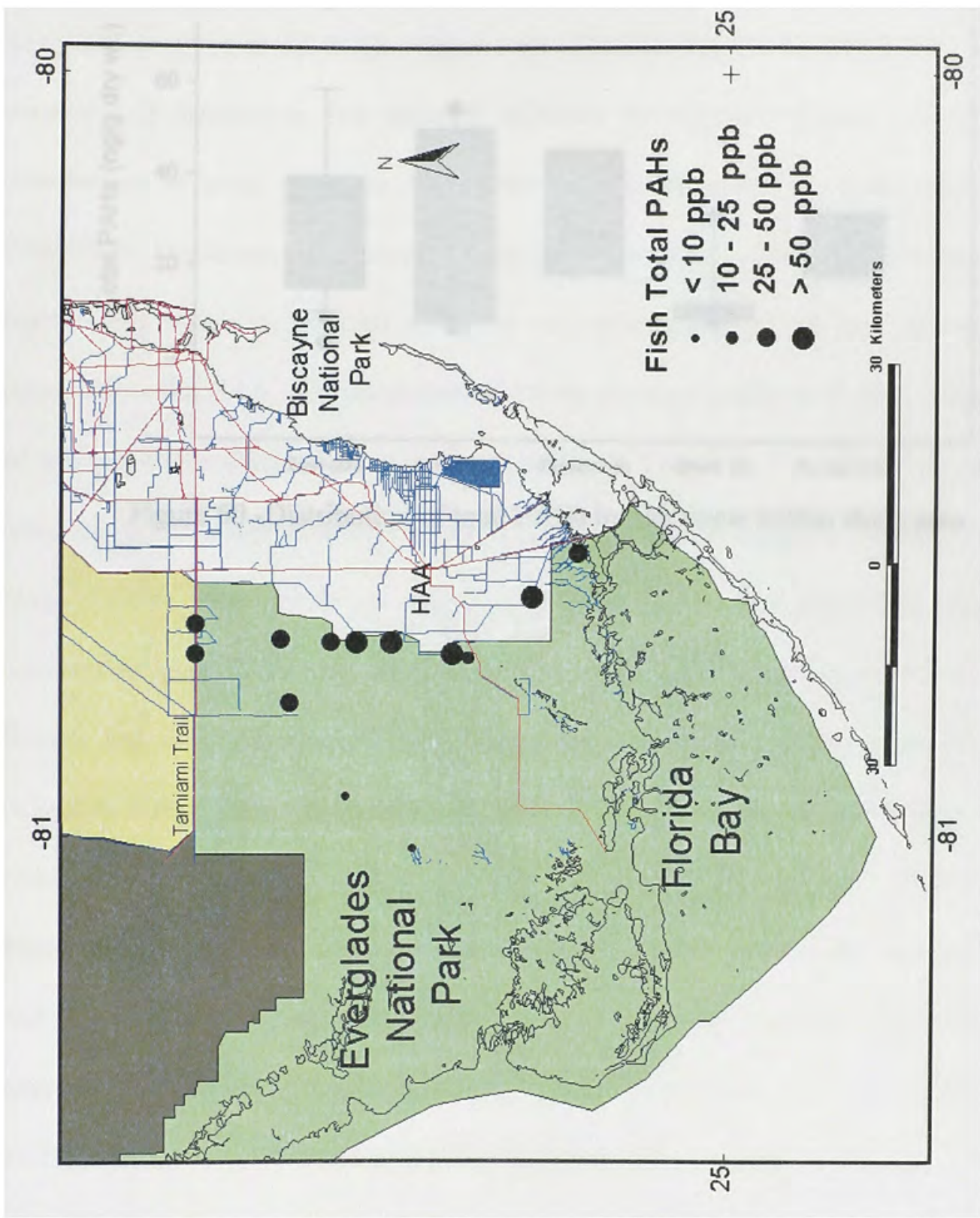

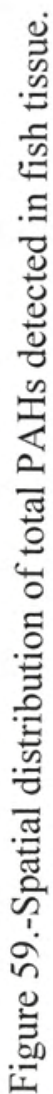




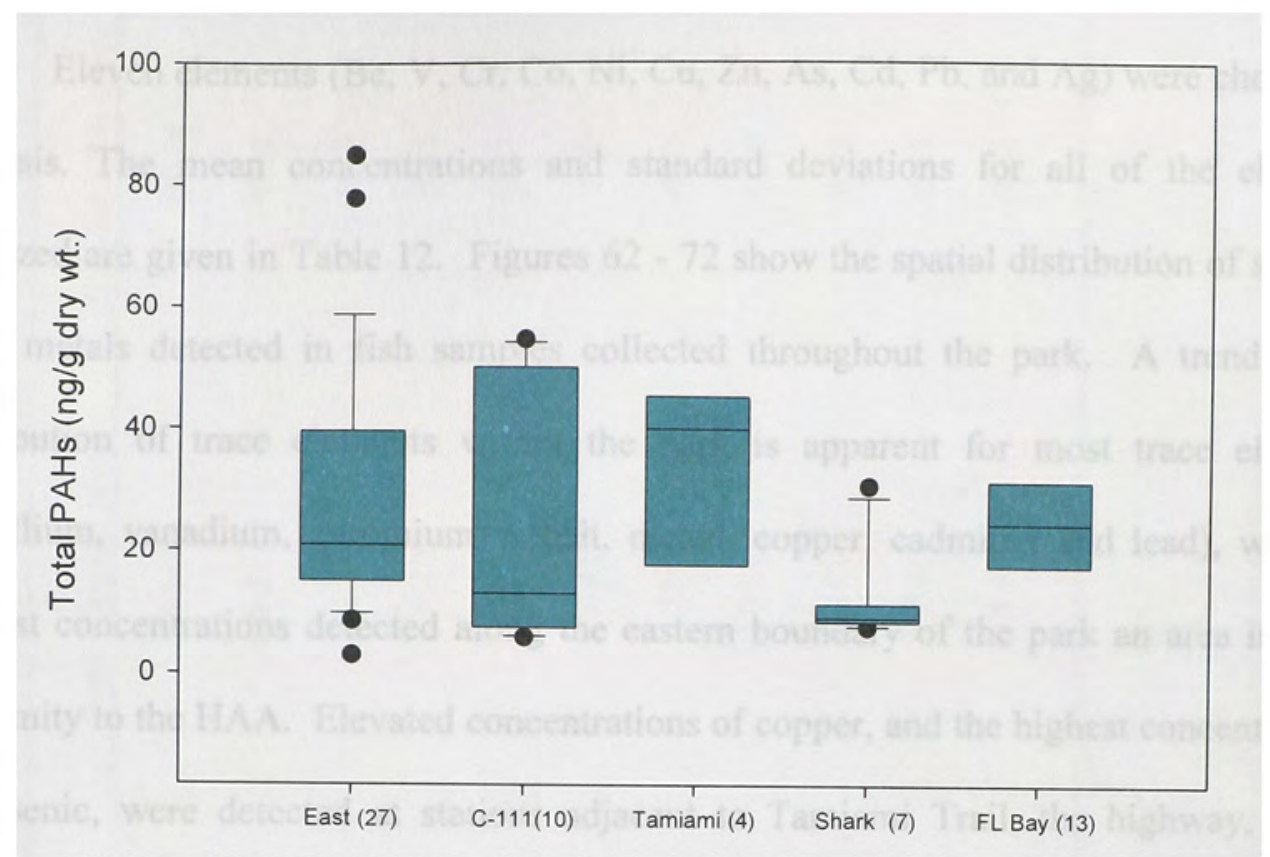

Figure 60.-Distribution of total PAHs in fish tissue within study area. 
3.4 Trace Elements in Whole Fish Tissue Samples

Eleven elements ( $\mathrm{Be}, \mathrm{V}, \mathrm{Cr}, \mathrm{Co}, \mathrm{Ni}, \mathrm{Cu}, \mathrm{Zn}, \mathrm{As}, \mathrm{Cd}, \mathrm{Pb}$, and $\mathrm{Ag}$ ) were chosen for analysis. The mean concentrations and standard deviations for all of the elements analyzed are given in Table 12. Figures $62-72$ show the spatial distribution of selected trace metals detected in fish samples collected throughout the park. A trend in the distribution of trace elements within the park is apparent for most trace elements (beryllium, vanadium, chromium, cobalt, nickel, copper, cadmium and lead), with the highest concentrations detected along the eastern boundary of the park an area in close proximity to the HAA. Elevated concentrations of copper, and the highest concentrations of arsenic, were detected at stations adjacent to Tamiami Trail, the highway, which traverses the northern boundary of ENP and connects the metropolitan area of MiamiDade County with the west coast of South Florida. Surprisingly, the highest concentrations of silver were detected in fish samples from the remote stations in Shark Slough but still below mean values detected elsewhere (0.01-1.2 ppm dry weight) (Kennish 1997). Zinc concentrations were in the range of $43-197$ ppm, which is consistent with values reported for fish in uncontaminated areas (Barwick 2003, Papagiannis 2004), but the highest concentrations were detected in the Eastern Boundary and Shark Slough. Comparisons of the concentration distributions of trace elements in whole fish tissue are given in figures $73-82$. Trace metal analysis of fish tissue in Florida Bay stations has not occurred at this time. 


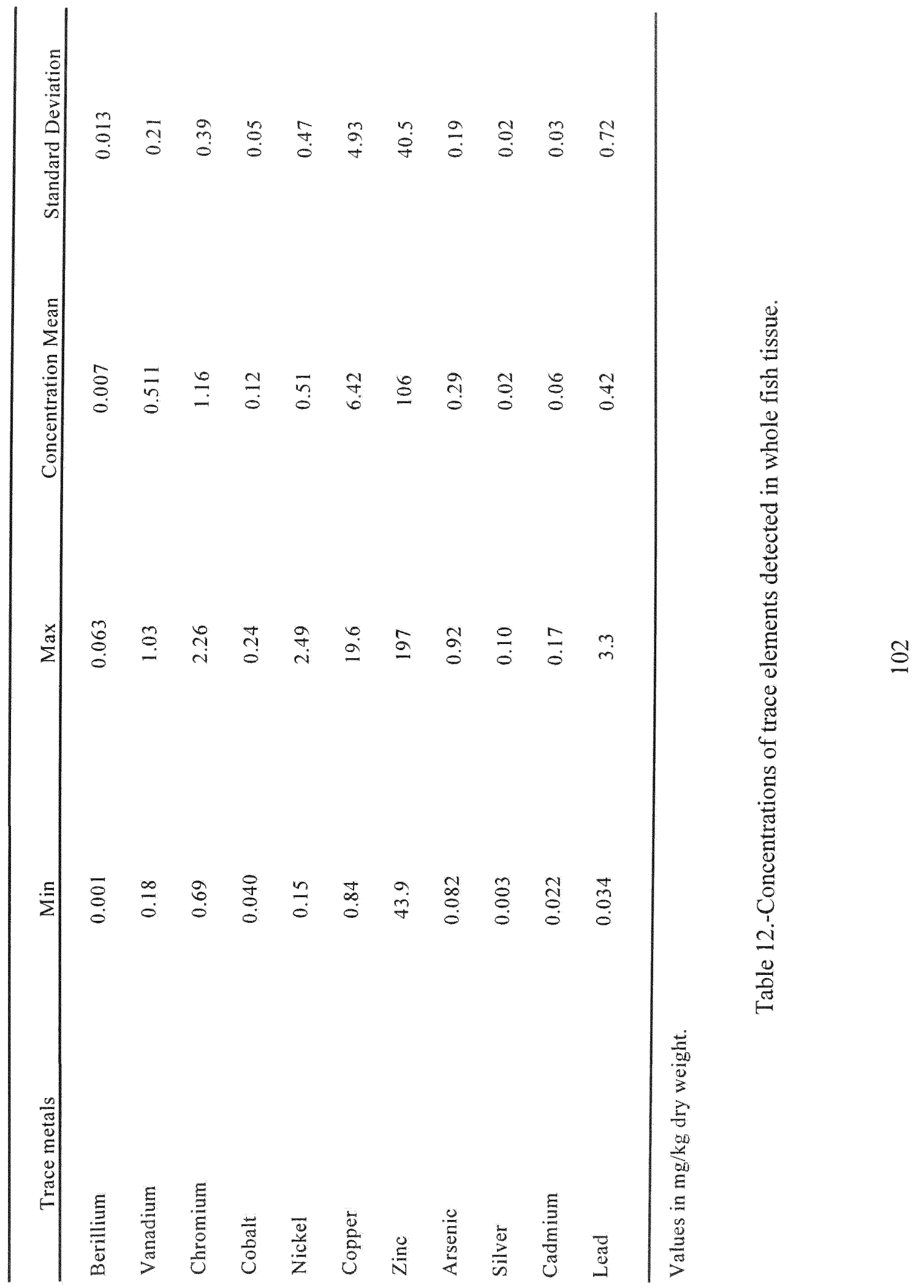




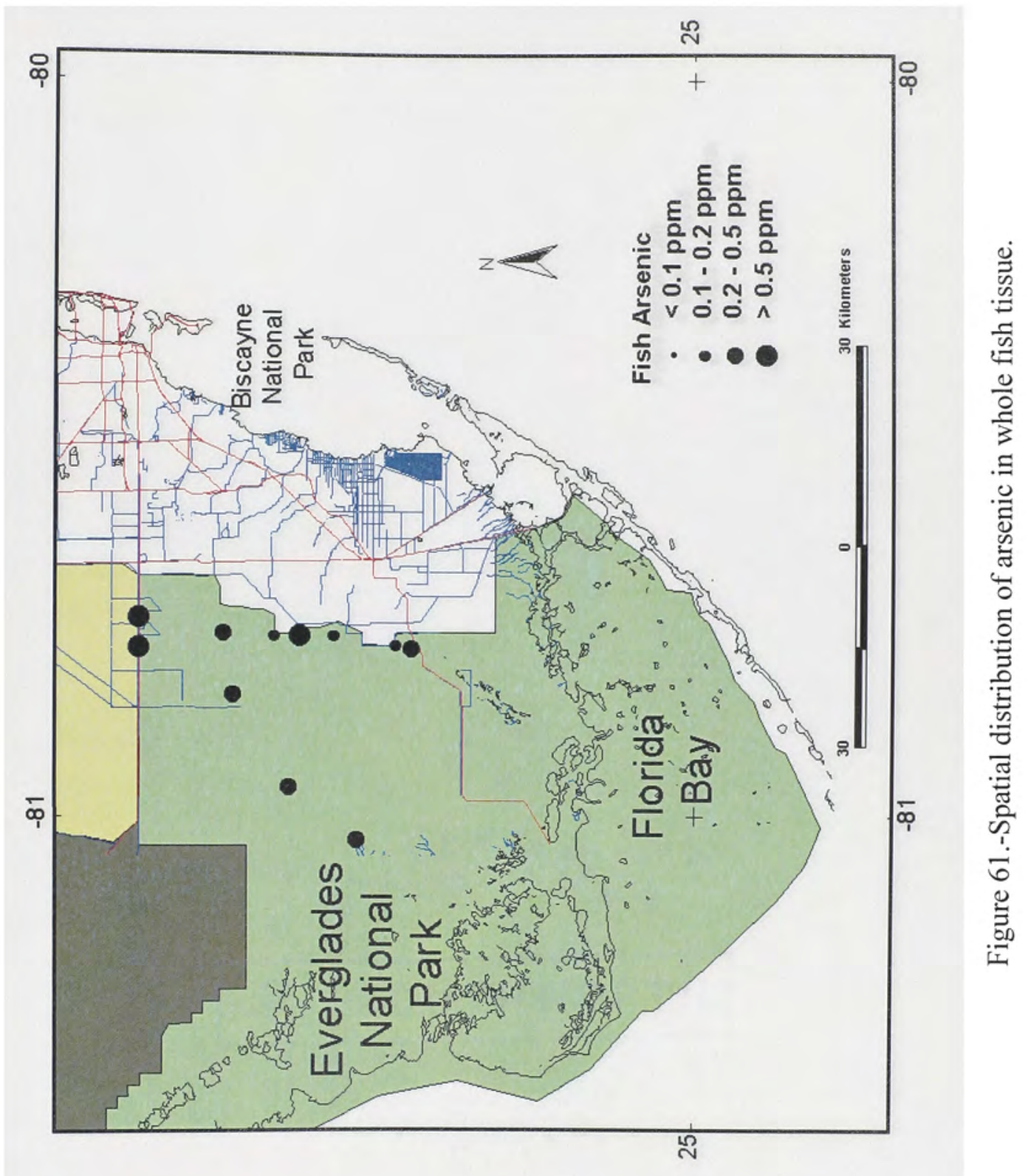

$\stackrel{9}{9}$ 


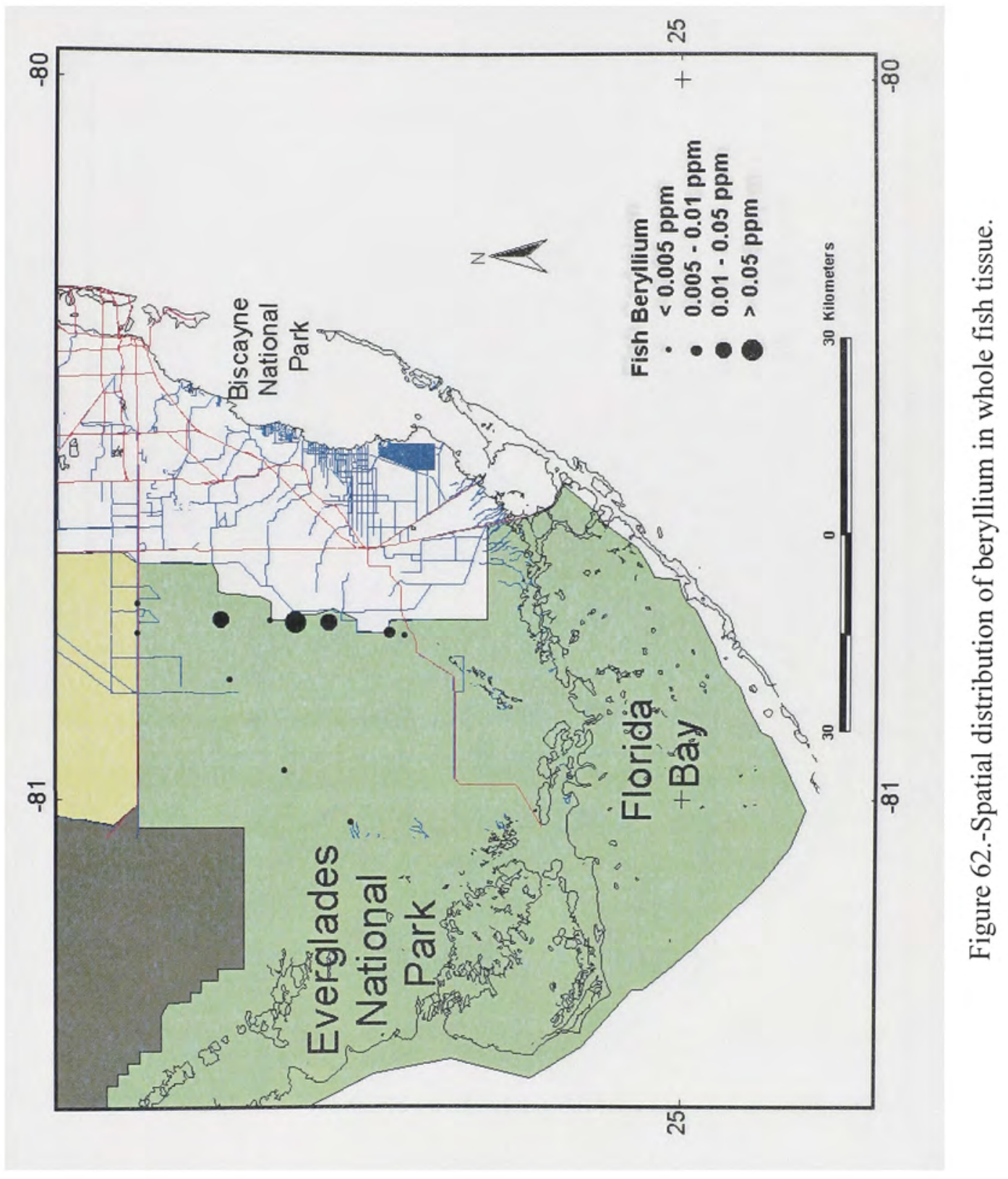




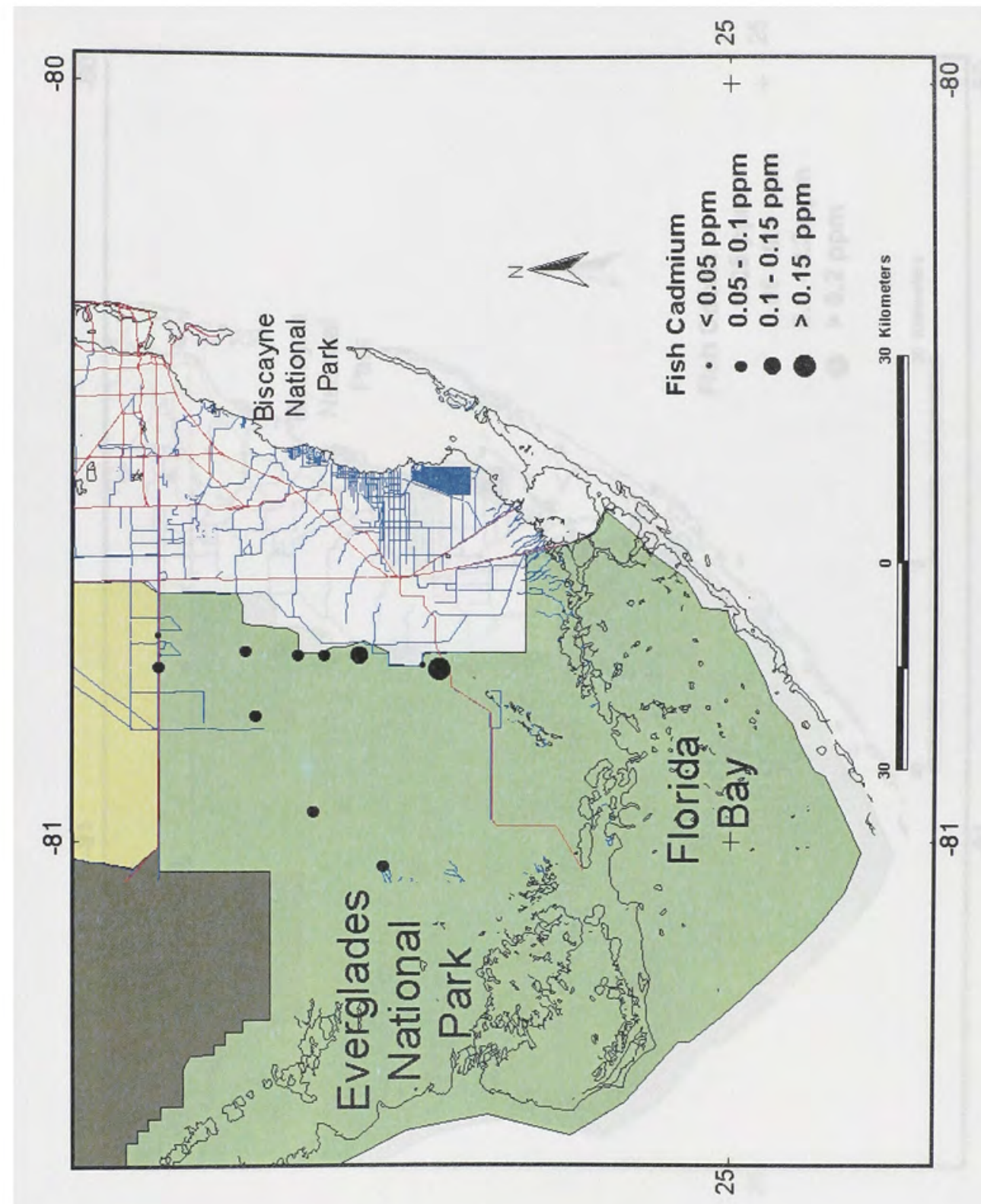

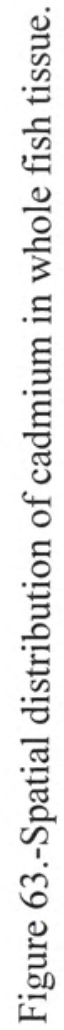




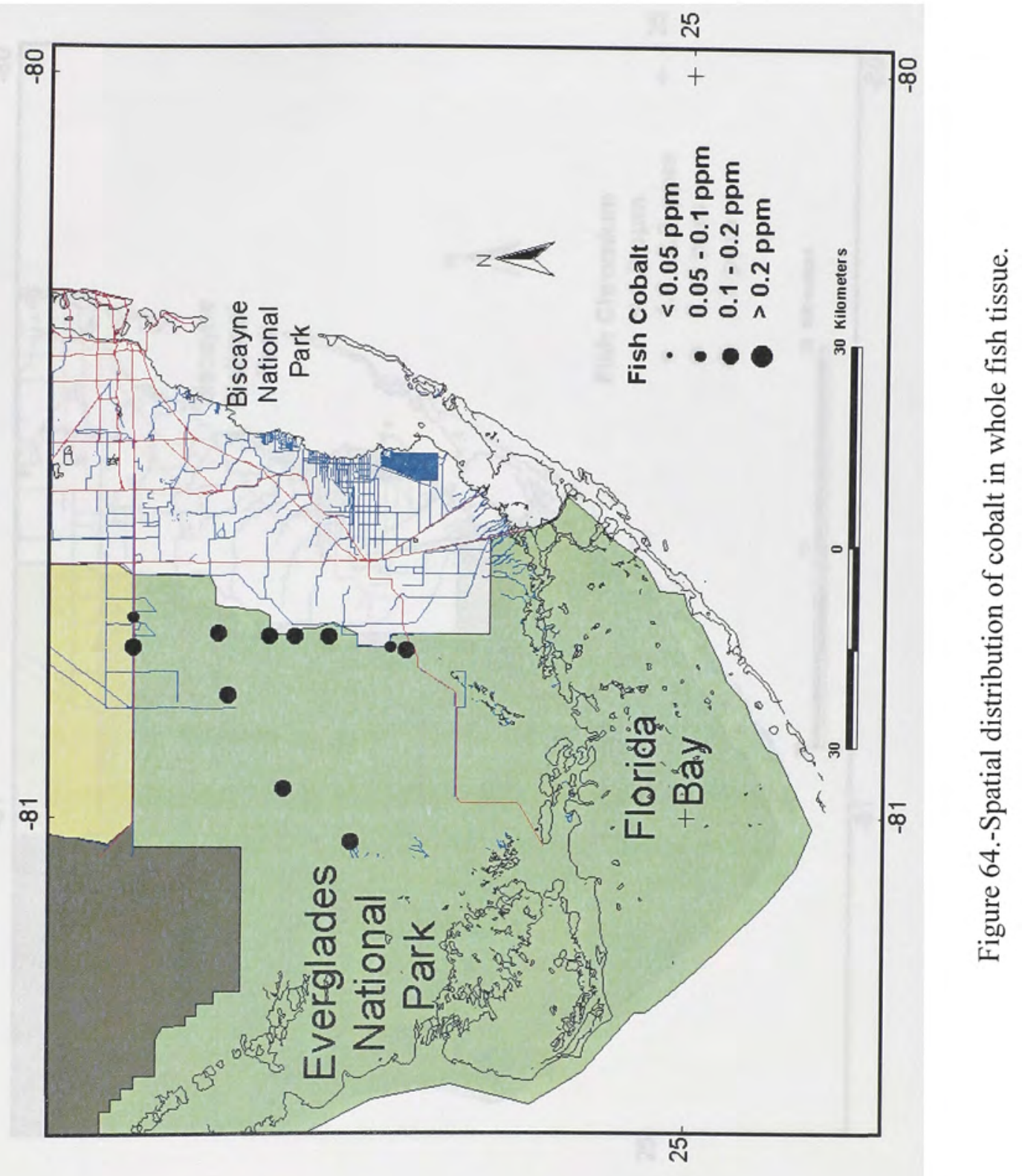




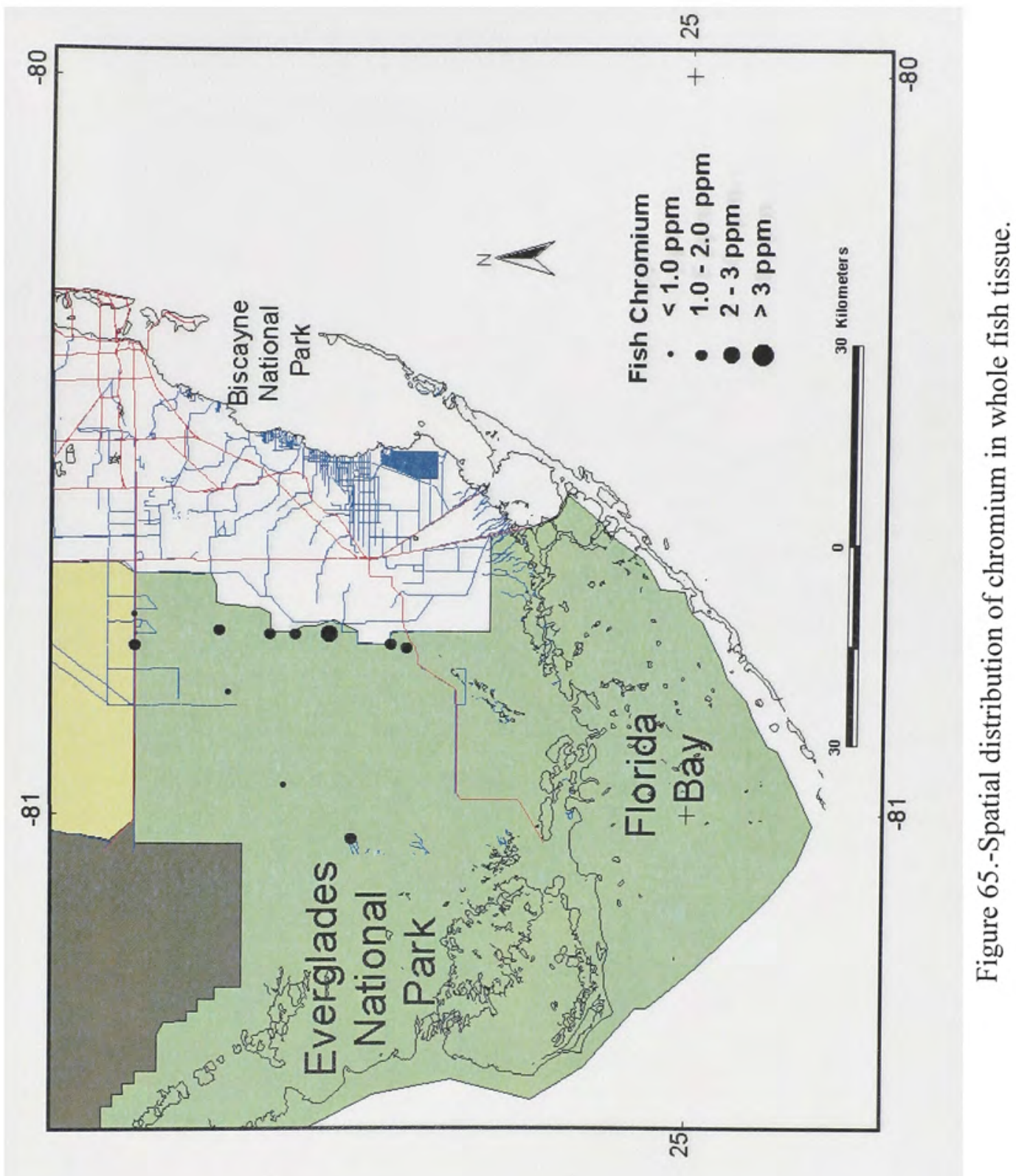

으 




$\stackrel{\circ}{9}$ 


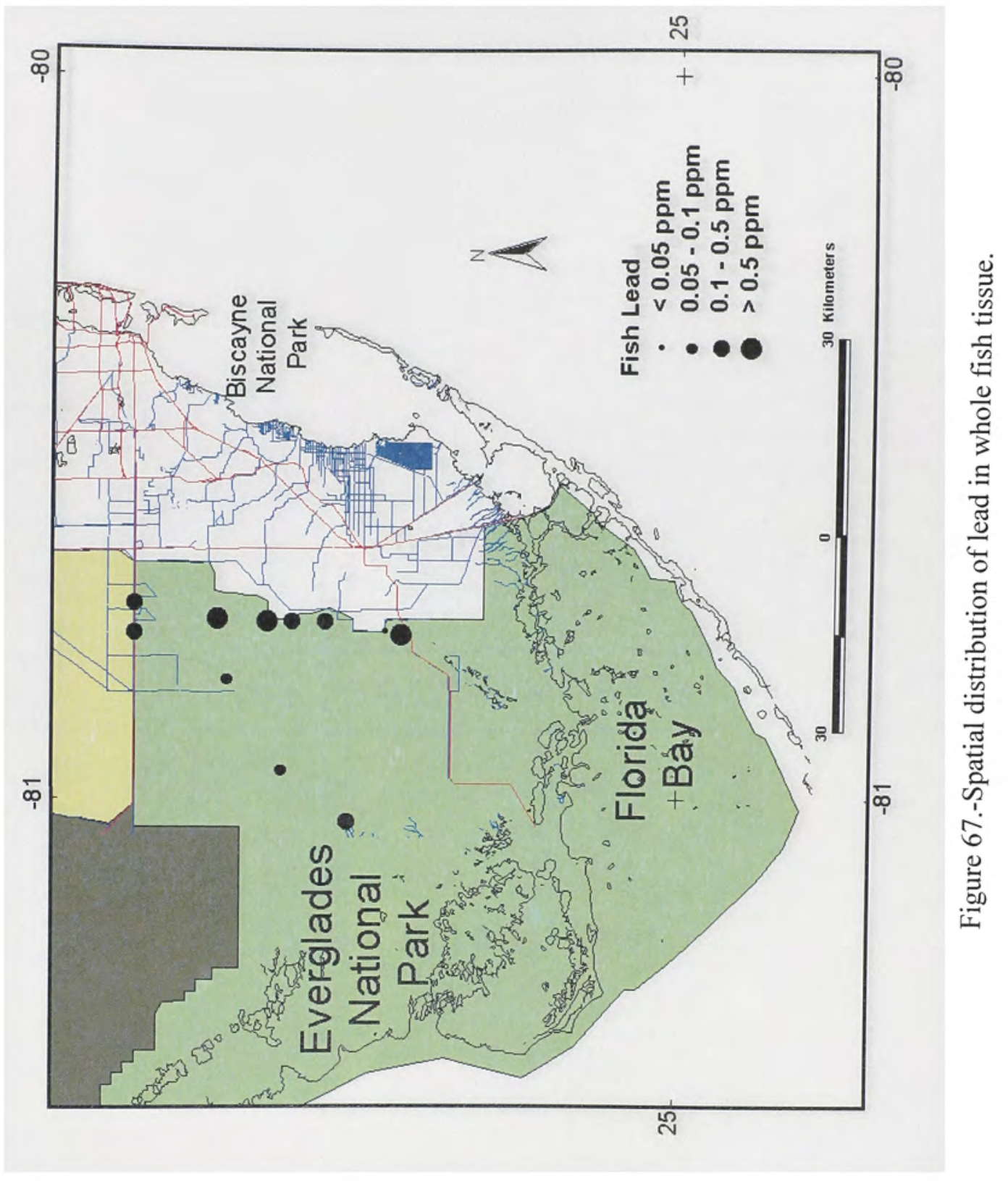




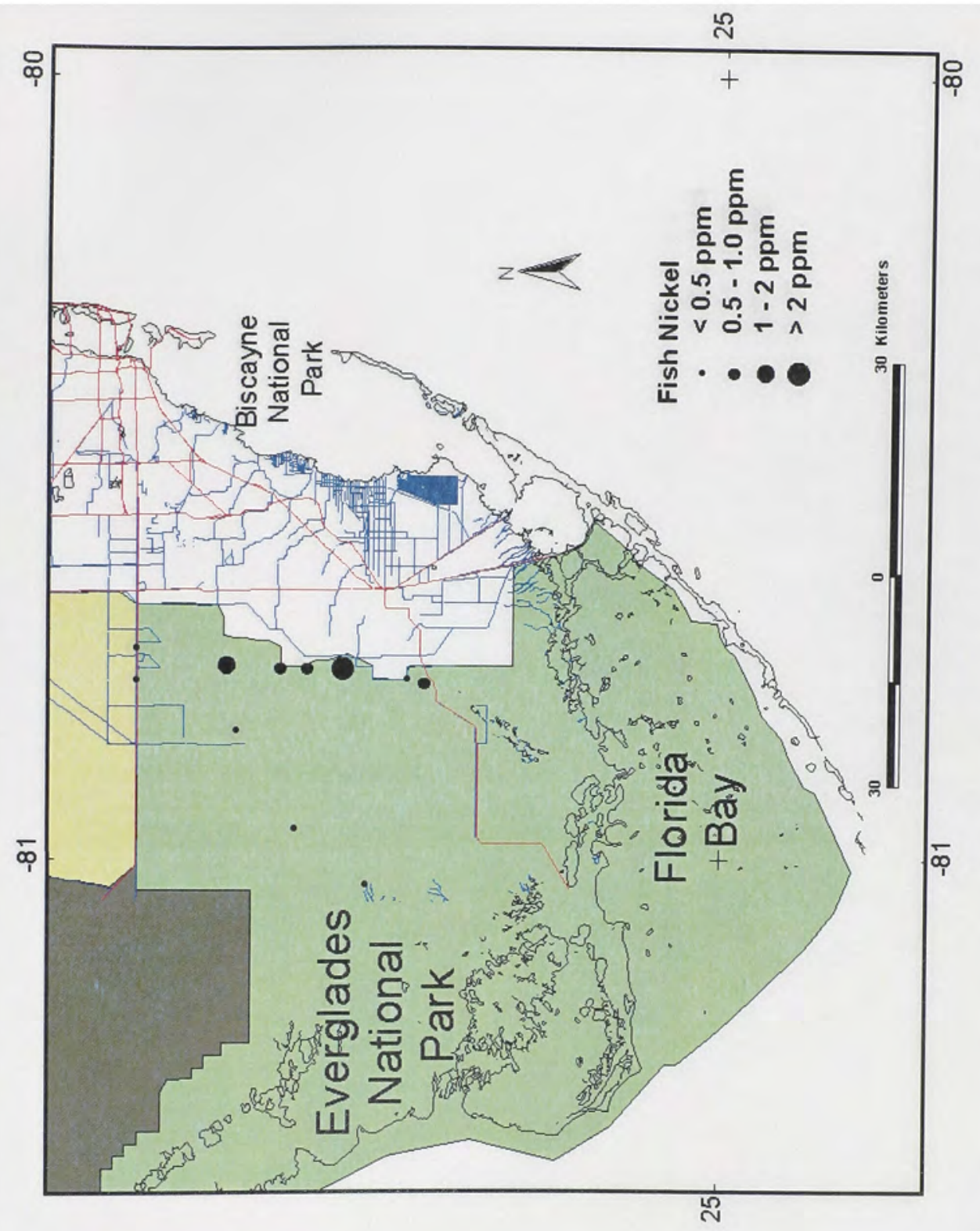

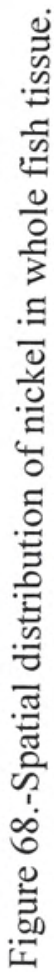




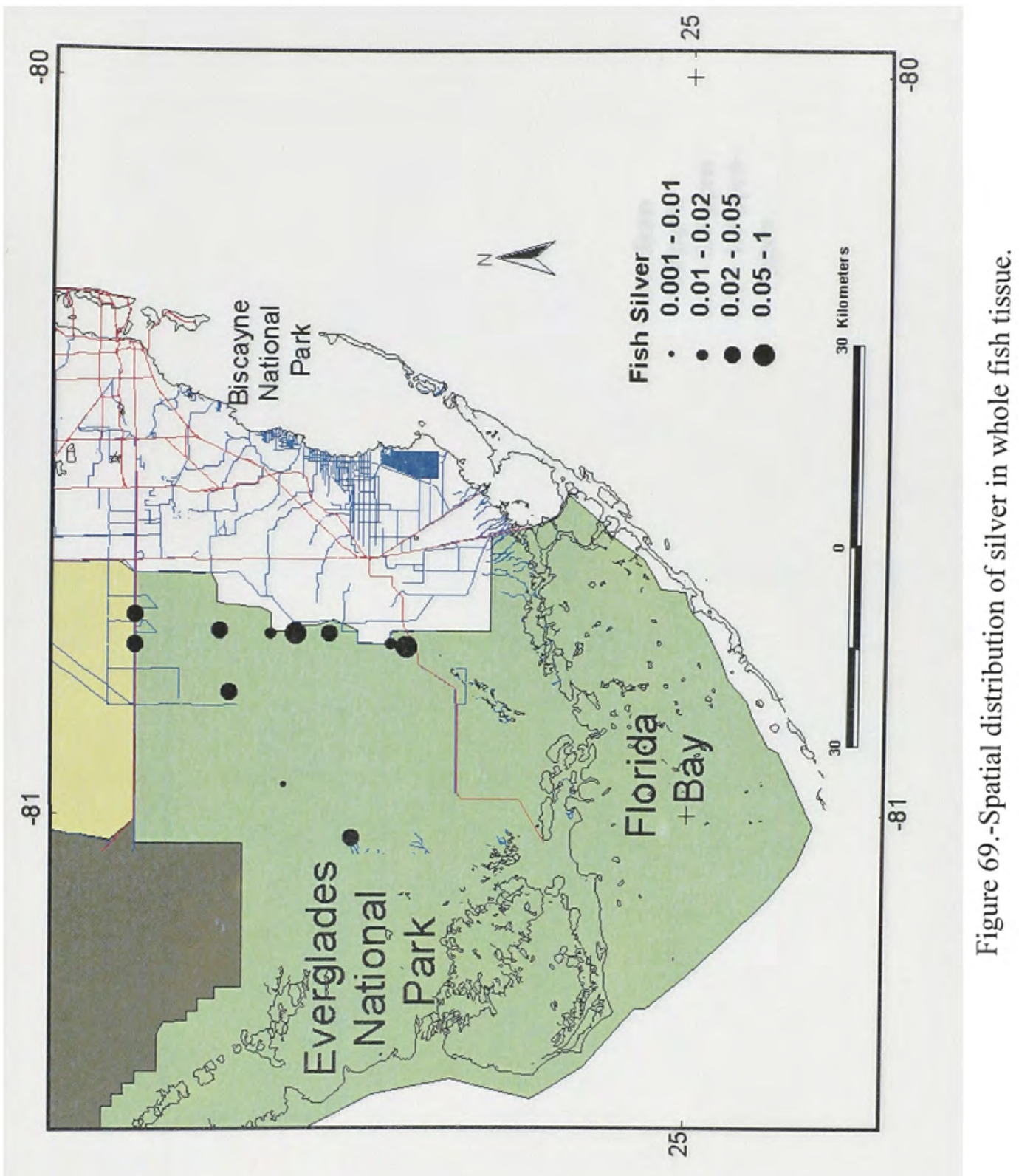









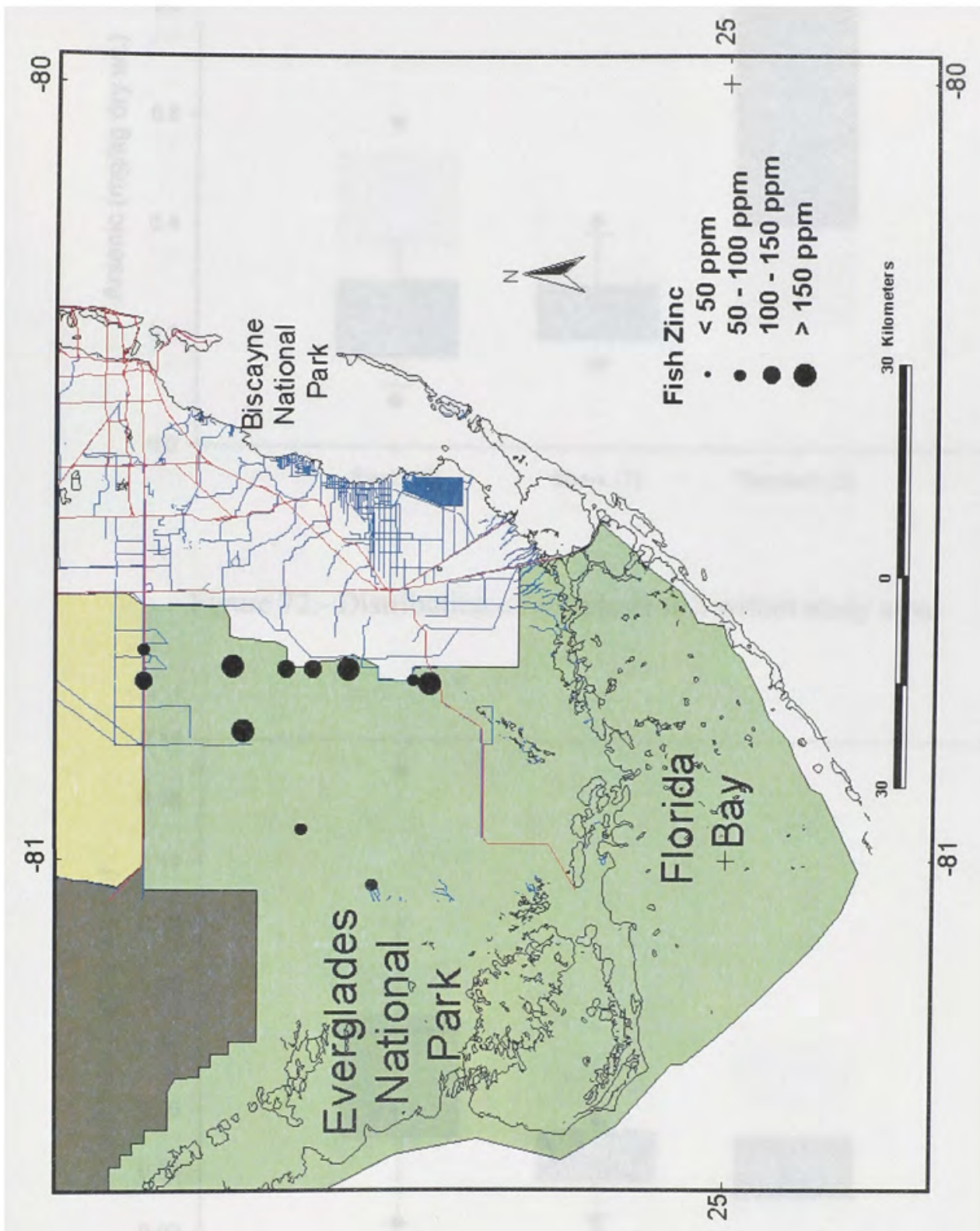






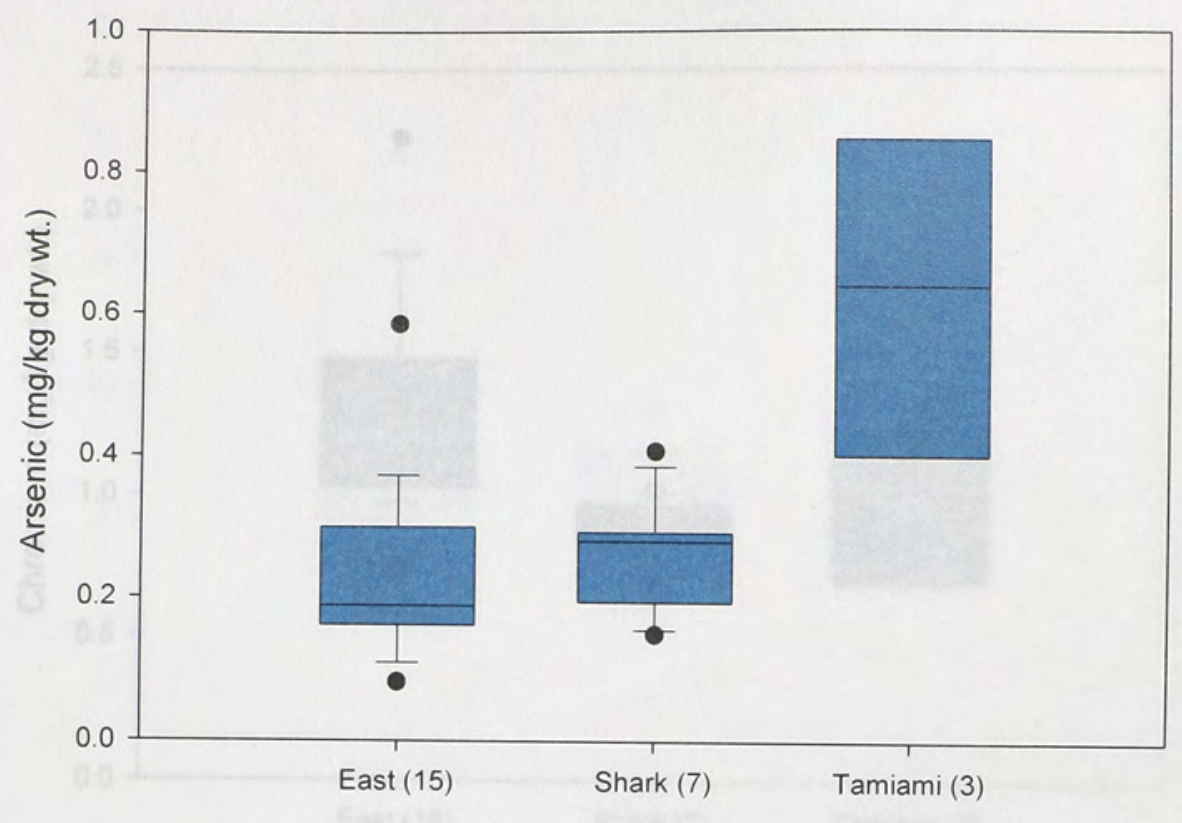

Figure 72.- Distribution of arsenic in fish within study area.

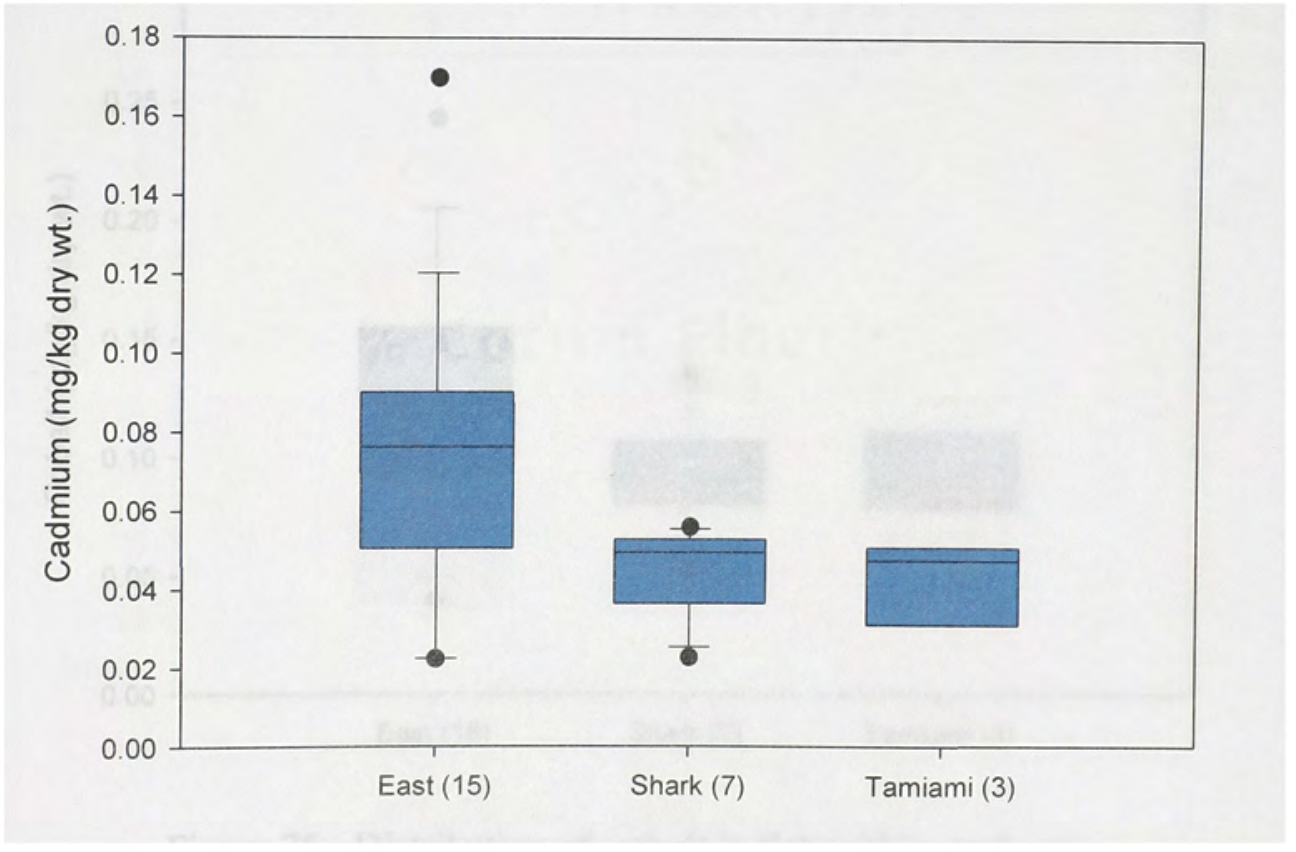

Figure 73.- Distribution of beryllium in fish within study area. 


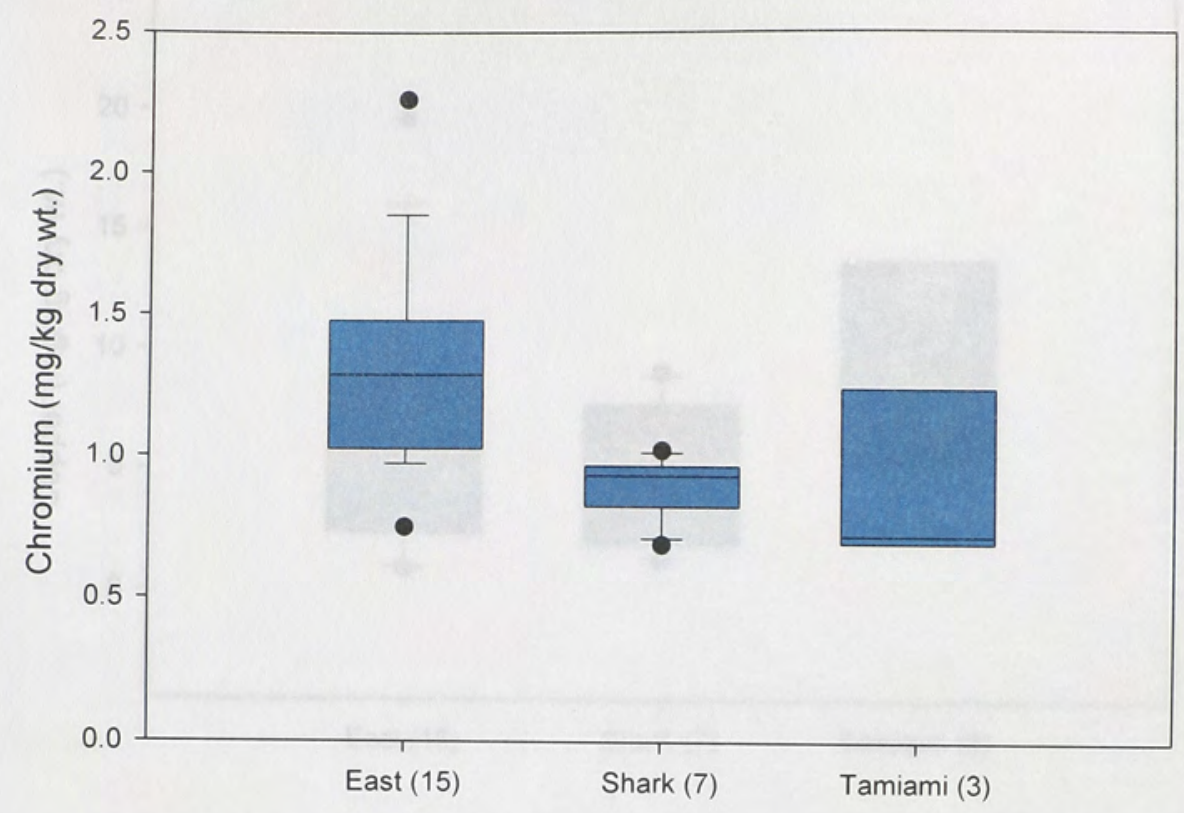

Figure 74.-Distribution of chromium in fish within study area.

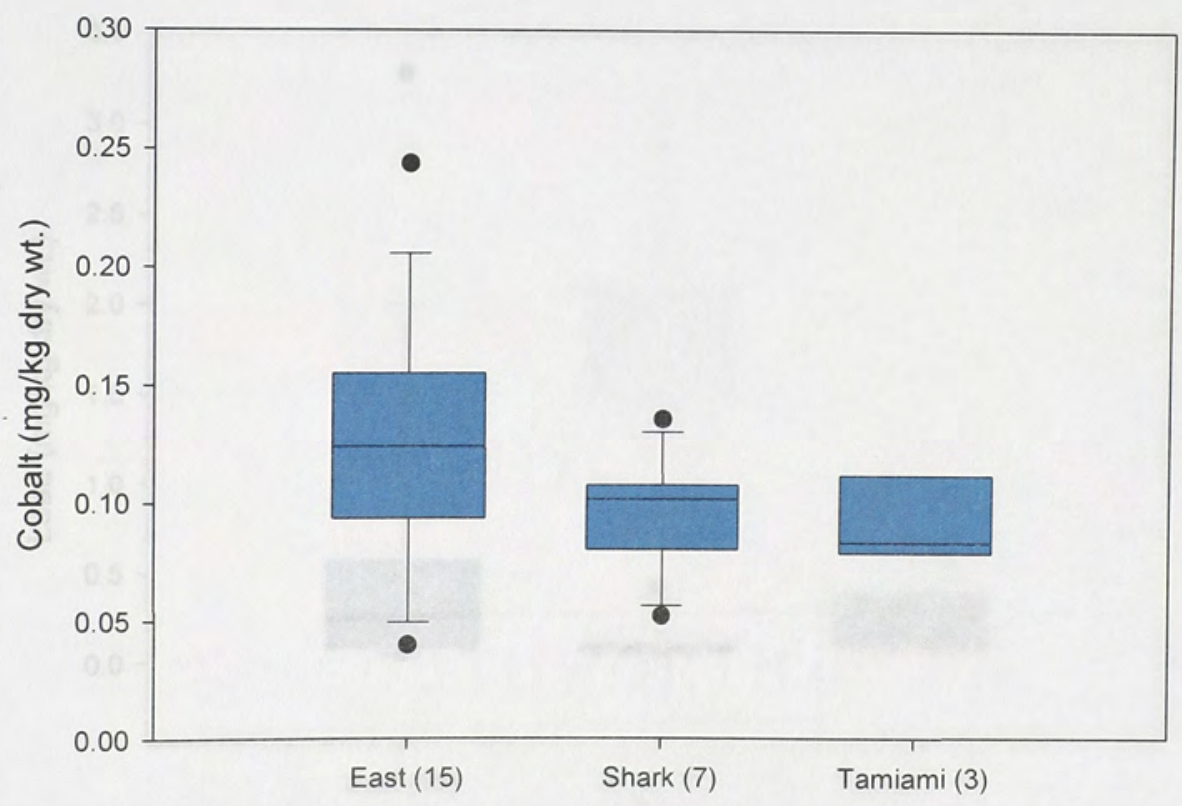

Figure 75.- Distribution of cobalt in fish within study area. 


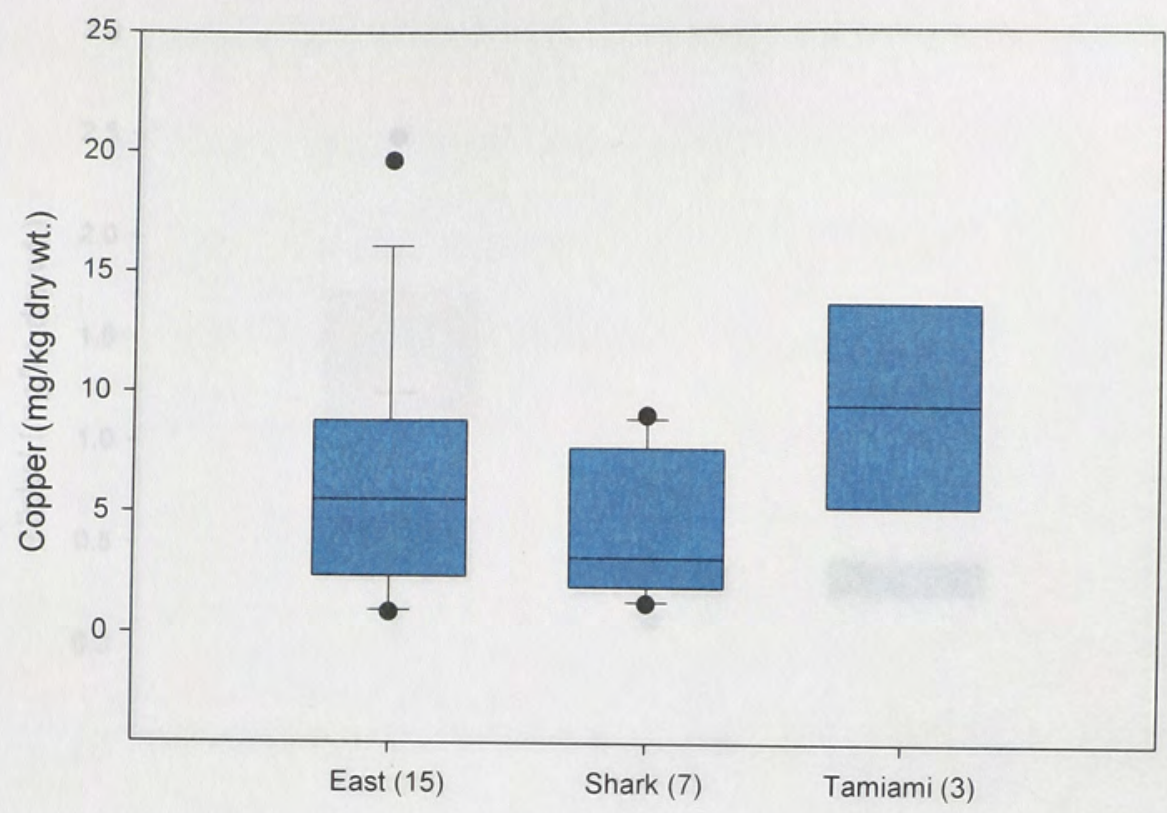

Figure 76.- Distribution of copper in fish within study area.

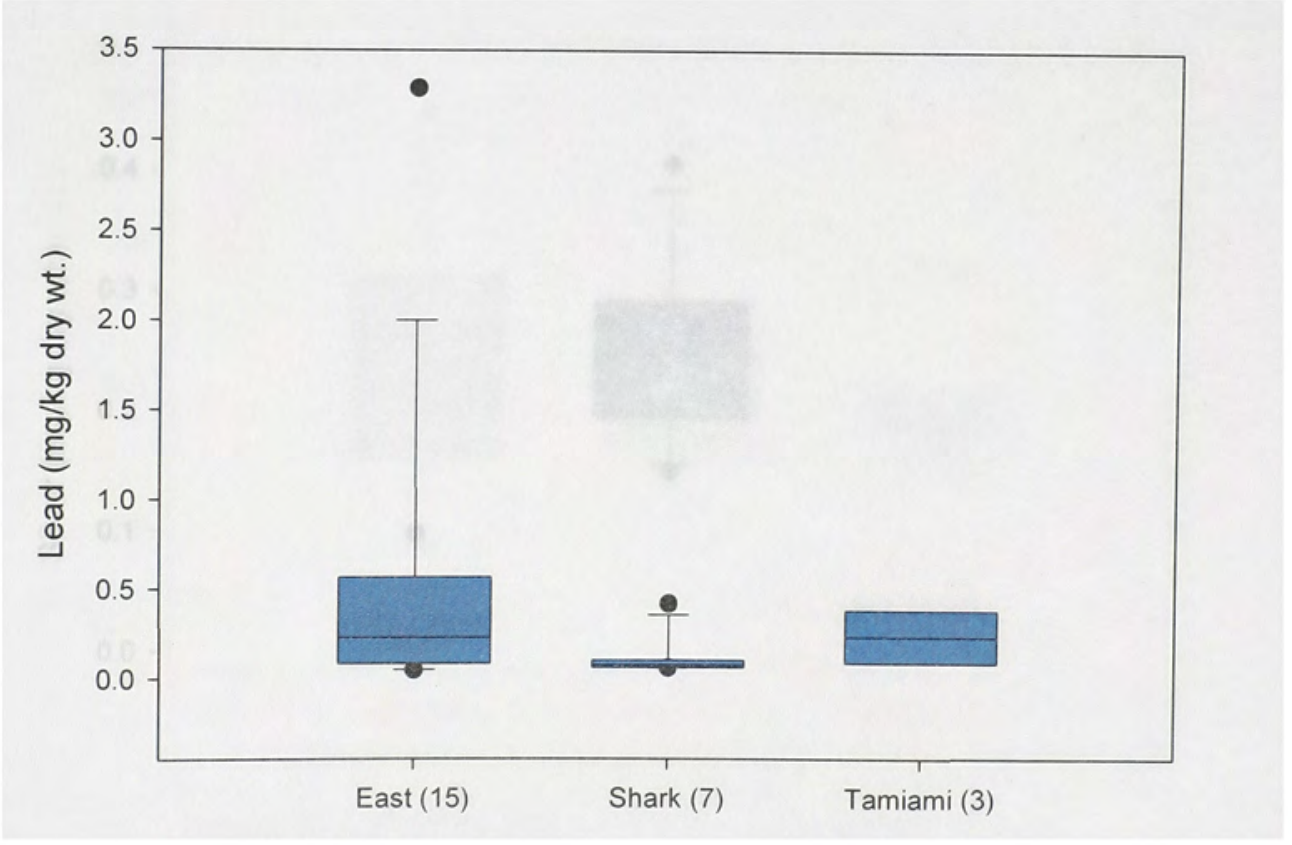

Figure 77.- Distribution of lead in fish within study area. 


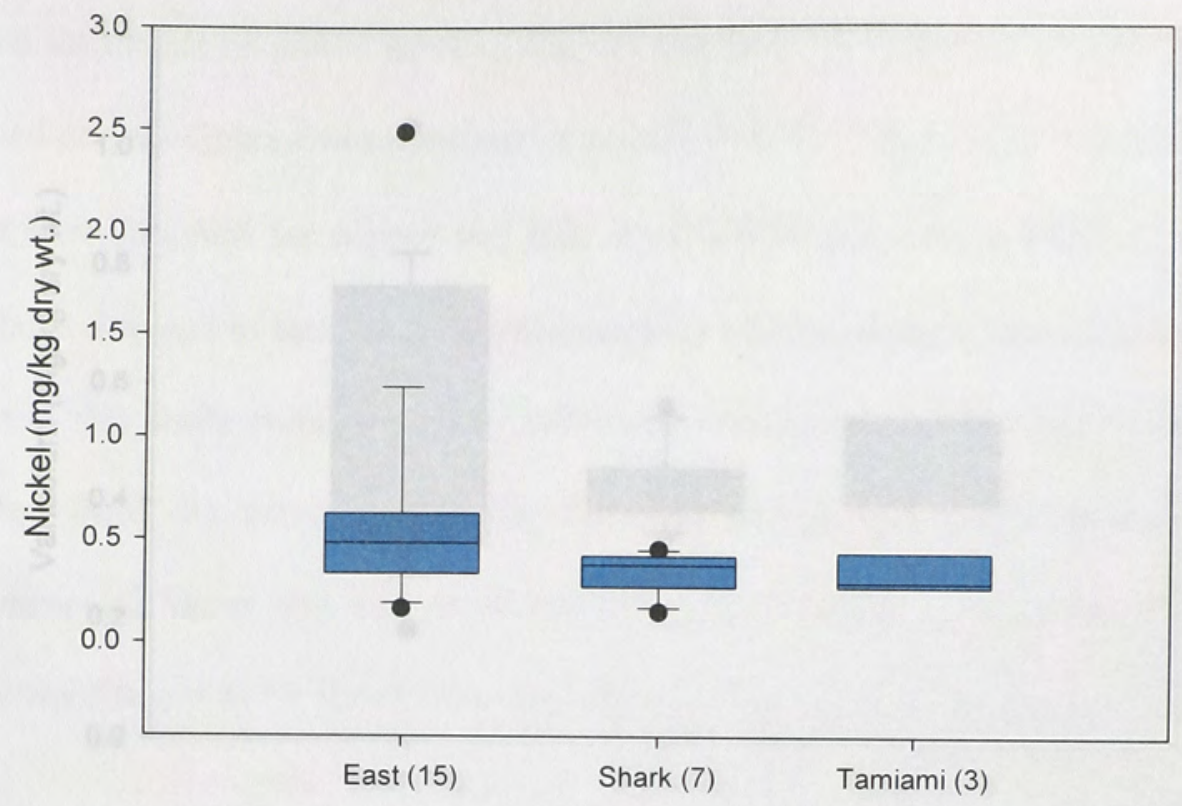

Figure 78.-Distribution of nickel in fish within study area.

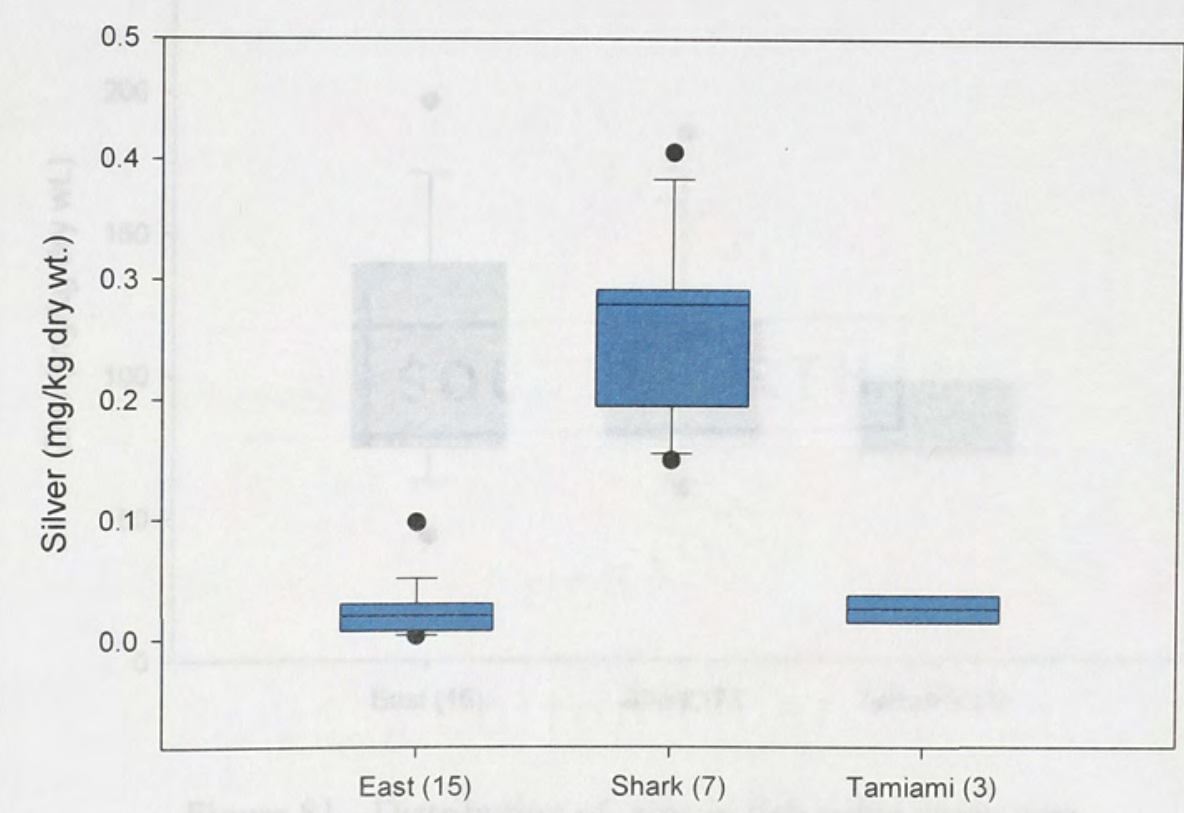

Figure 79.- Distribution of silver in fish within study area. 


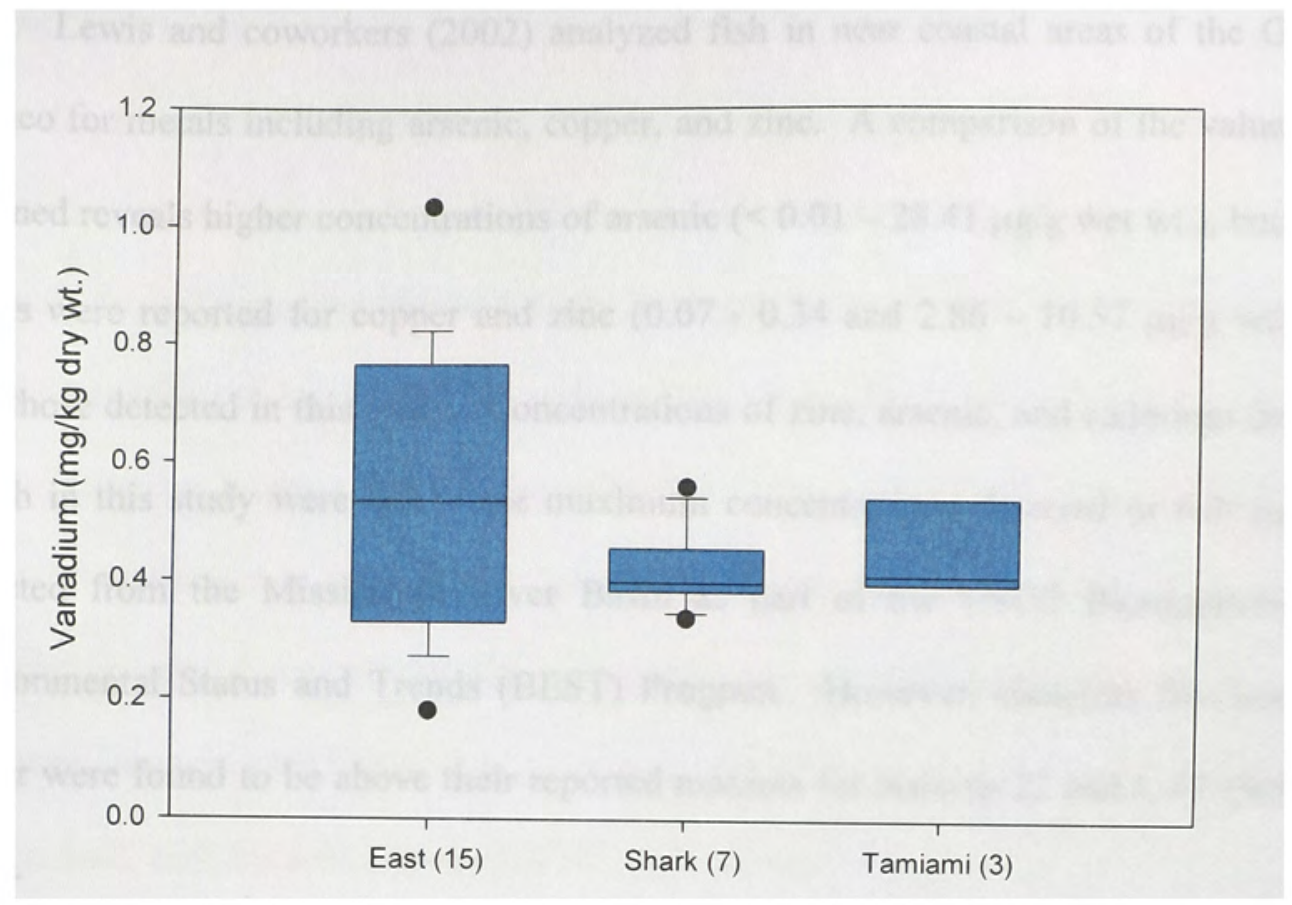

Figure 80.-Distribution of vanadium in fish within study area.

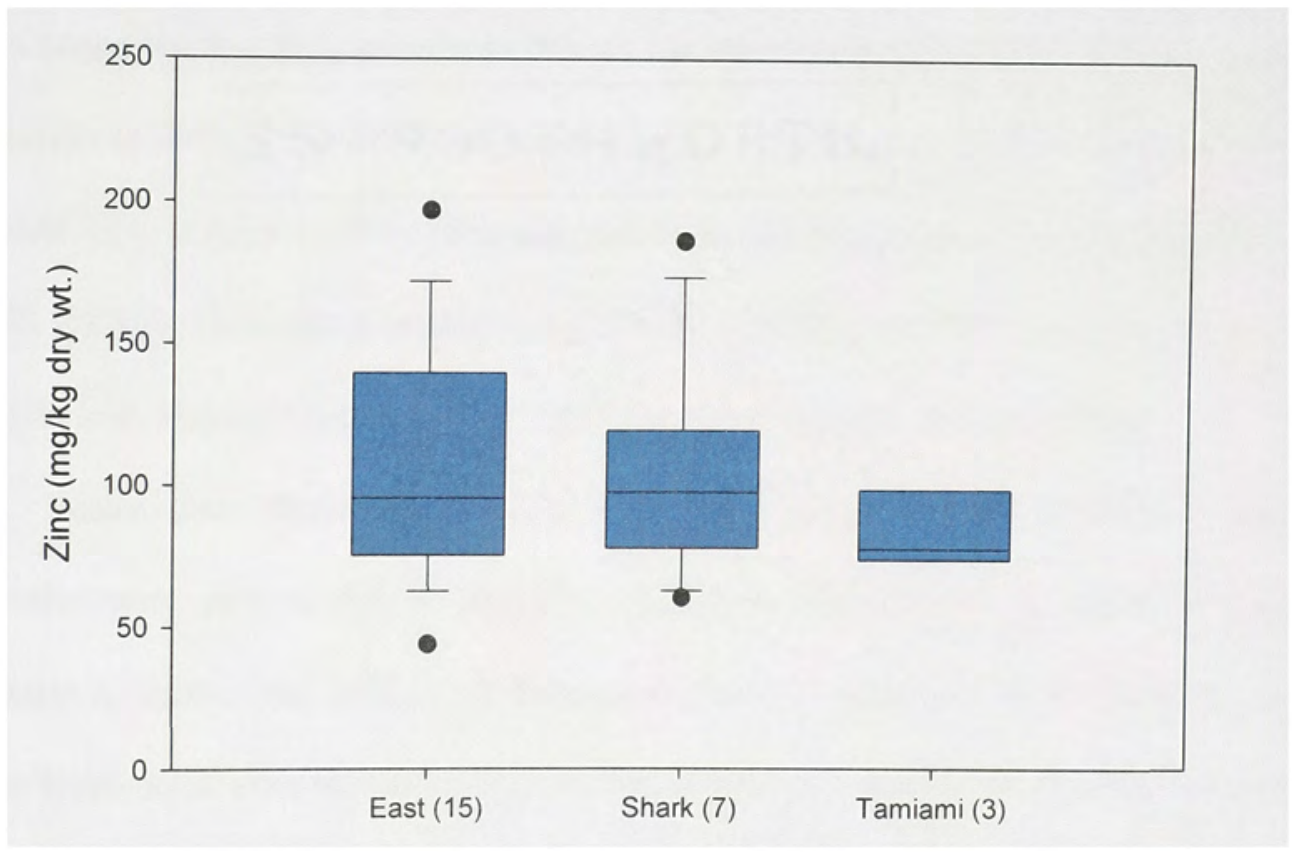

Figure 81.- Distribution of zinc in fish wthin study area. 
Lewis and coworkers (2002) analyzed fish in near coastal areas of the Gulf of Mexico for metals including arsenic, copper, and zinc. A comparison of the values they obtained reveals higher concentrations of arsenic $(<0.01-28.41 \mu \mathrm{g} / \mathrm{g}$ wet wt. $)$, but lower values were reported for copper and zinc $(0.07-0.34$ and $2.86-10.57 \mu \mathrm{g} / \mathrm{g}$ wet wt.), than those detected in this study. Concentrations of zinc, arsenic, and cadmium detected in fish in this study were below the maximum concentrations detected in fish samples collected from the Mississippi River Basin as part of the USGS Biomonitoring of Environmental Status and Trends (BEST) Program. However, elements like lead and copper were found to be above their reported maxima for stations 22 and L-67 (Schmitt, 2002). 


\section{CONCLUSIONS}

From the data obtained during the course of this study one key conclusion can be drawn: the concentrations of contaminants in both sediment and fish tissue surveyed in this study from Everglades National Park, Biscayne National Park, and Florida Bay, are low in comparison to impacted areas and similar to those found in pristine areas (Kennish 1997). However, it appears that anthropogenic activities have resulted in the enrichment of certain contaminants at various locations throughout the study area. Compounds of particular concern, based on the observed concentrations and environmental assessment guidelines, include: lead, chromium, arsenic, nickel, and DDT and its metabolites. Arsenic, lead, and chromium exceeded PEL criteria in 9, 5, and 5\% of the ENP sediment samples and exceeded TEL criteria in 32,14 and $27 \%$ of the samples respectively. Nickel exceeded the TEL criteria in 5\% of the ENP sample stations. Arsenic exceeded TEL levels in $44 \%$ of the BNP sediment samples. Dieldrin, p-p'DDT, and p-p'DDD all exceeded TEL criteria in 5\% of the samples analyzed while p-p'DDE exceeded the TEL in $14 \%$ of the sediment samples respectively. $\mathrm{PCB}$ and $\mathrm{PAH}$ concentrations were generally low, and only one station in BNP exceeded the TEL for total PCBs.

Tissue data show clear indications that currently used pesticides such as endosulfan may pose a risk to sensitive biological endpoints and further studies are necessary to assess the effects of long-term chronic exposure particularly to higher trophic level organisms where biomagnification could be important. Endosulfan, and its sulfate have been reported in multiple matrices (water, sediments and oysters) along the southern portions of Miami-Dade county and Florida Bay. Endosulfan sulfate was detected in $87 \%$ of the tissue samples and $64 \%$ of the sediment samples. 
In the case of organochlorine pesticides which are still in use, specifically endosulfan and its metabolites, a trend is apparent with the highest concentrations of these compounds in close proximity to areas of intense agricultural production such as the Homestead Agricultural Area. Other organochlorine pesticides such as DDT, and its metabolites DDD and DDD, which are no longer in use, were also detected more frequently near agricultural areas, however the presence of these compounds were also detected in more remote areas suggesting that long range transport of these compounds is occurring throughout South Florida.

The distribution of Polychlorinated Biphenyls is relatively uniform throughout the areas sampled with the exception of one station sampled in Biscayne Bay, near a municipal landfill, which may be the source of the elevated levels of PCBs detected at that station. The observed concentrations for PCBs in both sediment and fish tissue throughout most of the stations sampled are low and are not expected to be of significant environmental concern based upon available sediment quality guidelines. Overall, it appears that PCB distribution in this area is probably due mostly to atmospheric deposition from long-range global dispersion.

Polycyclic Aromatic Hydrocarbon (PAH) concentrations detected throughout the study area are relatively low in comparison to other studies. The distribution of PAHs in sediments show more elevated concentrations at stations located in close proximity to Tamiami Trail indicating street runoff as a potential source. An examination of the ratios of Benzo[a]pyrene/Benzo[ghi]perylene also indicate that automobile emissions are a predominant source of PAHs at most stations throughout the study area. The highest concentration of total PAHs detected in this study $(912 \mathrm{ng} / \mathrm{g})$ was detected at the BNP 
station (BBBP 1) located near a landfill and a marina, all other detections in BNP and Florida Bay were lower than those found in Everglades National Park.

Trace metal data indicate a potential for sediment enrichment above naturally occurring levels for elements including arsenic, chromium, copper, lead, nickel, and zinc at several of the stations sampled within ENP as well as arsenic in BNP. The trends in distribution show the highest concentrations of beryllium, vanadium, and chromium found near the east boundary of the park as well as in Shark Slough, while cobalt and nickel concentrations are highest at the Eastern boundary, Shark Slough and Tamiami Trail regions. Copper, zinc, arsenic and lead all showed elevated concentrations along the Eastern boundary, and Tamiami Trail. Trace metal distribution in fish tissue show similar trends to the sediment data with the exception of zinc, which had high concentrations at all stations. The reasons for the enrichment of this particular group of metals in ENP are not yet clear, but anthropogenic emissions from the urban areas of South Florida are the most likely source. 


\section{FUTURE WORK}

As a result of this study a snapshot view of the occurrence of a wide variety of common contaminants throughout Everglades National Park, Biscayne National Park, and Florida Bay was produced. The purpose of this study was three fold: to provide background information on the general status of National park lands with respect to contamianants, to evaluate which areas of the region are most likely impacted by anthropogenic activities and to identify which contaminants should be monitored more closely to assess future sustainability of valuable resources along ENP and BNP. Based on the results, areas that should be monitored more closely in the future include the C111 drainage basin and the east boundaries of ENP along the L31-N canal. Both regions will be targeted for major changes of water delivery that may affect future transport of contaminants to the south-eastern Everglades as a result of CERP.. Another area of concern is Shark Slough, which contains stations that had elevated concentrations of both inorganic and organic contaminants despite their remote location. More stations should be monitored along this transect in order to better assess the transport of contaminants in this region of ENP. Although this study focused on organochlorine pesticides, most of these are no longer in use, and monitoring for more currently applied pesticides such as organo-phosphates and pyrethroids should be considered in future Everglades monitoring programs.

The results of these studies will also form the basis of an ecological risk assessment study conducted at the FIU, to determine the potential consequences of the presence and distribution of these contaminants to biological resources inhabiting these parks. 


\section{REFERENCES}

ATSDR-Agency for Toxic Substances and Disease Registry (2000). Toxicological Profile for Endosulfan. U.S. Department of Health and Human Services, Public Health Service.

Baird, C., (1999) Environmental Chemistry. W.H. Freeman and Company. NY.

Barwick, M., Maher, W. (2003). Biotransference and biomagni.cation of selenium copper, cadmium, zinc, arsenic and lead in a temperate seagrass ecosystem from Lake Macquarie Estuary, NSW, Australia. Marine Environmental Research 56, 471-502.

Buehler, S. S., Basu, I., Hites, R. A., (2001). A comparison of PAH, PCB, and pesticide concentrations in air at two rural sites on Lake Superior. Environmental Science and technology 35, 2417-2422.

Cantillo, A., Lauenstein, G. and O'Connor, T. (1997) Mollusk and sediment contaminant levels and trends in South Florida coastal waters. Marine Pollution Bulletin, 34(7):51-521.

Chen, M. (2001). Arsenic background concentrations in Florida, U.S.A. surface soils: determination and interpretation. Environmental Forensics 2, 117-126.

Chirenje, T., Ma, L. Q., Reeves, M., and Szulczewski, M. (2004). Lead distribution in near-surface soils of two Florida cities: Gainesville and Miami. Geoderma $119,113-120$.

Cousins, I. T., Beck, A. J., Jones, K. C. (1999). A review of the processes involved in the exchange of semi-volatile organic compounds (SVOC) across the air-soil interface. The Science of Total Environment, 228, 2-24.

Cousins, I. T., Mclachlan, M. S., Jones, K. C. (1999). Lack of an aging effect on the soilair partitioning of Polychlorinated Biphenyls. Environmental Science and Technology, 32, 2734-2740.

Dvonch, J. T., Graney, J. R., Keeler, G. J., Stevens, R. K. (1999). Use of elemental tracers to source apportion mercury in south Florida precipitation. Environmental Science and Technology, 33, 4522-4527.

Erickson, M. D., (1997) Analytical Chemistry of PCBs. CRC Press LLC.

Gibbs, R. J., (1973). Mechanisms of trace metal transport on rivers. Science 180, $71-72$. 
Graney, J. R., Dvonch, J. T., Keeler, G. J. (2004). Use of multi-element tracers to source apportion mercury in south Florida aerosols. Atmospheric Environment $38,1715-1726$.

Haag, K. M., McPherson, B. F. (1997). Organochlorine pesticides and PCBs in Southern Florida Fishes: Then and now. U.S. Geological Survey, U.S. Department of Interior, Fact Sheet FS-110-97.

Hites, R. A.,Eisenreich, S. J. (1987). Sources and Fates of Aquatic Pollutants, Advances in chemistry series 216. American Chemical Society, Washington, DC.

Jaffe, R. (1991). Fate of hydrophobic organic pollutants in the aquatic environment: a review. Environmental Pollution 69, 237-257.

Kennish, M. J. (1997). Practical handbook of estuarine and marine pollution. CRC Press, Inc.

Lang, Q., Zhang, Q, Jaffe, R. (2002). Organic aerosols in the Miami area, USA: temporal variability of atmospheric particles an wet/dry deposition. Chemosphere 47, 427441.

Lewis M. A., Scott I. S., Bearden D. W., Quarles R. L., Moore J., Strozier E. D., Silvertsen S. K., Dias A. R., Sanders M. (2002). Fish tissue quality in nearcoastal areas of the Gulf of Mexico receiving point discharges. The Science of the Total Environment, 284, $249-261$.

Li, X., Shen, Z., Wai, O.W.H. and Li, Y., (2000). Chemical Partitioning in heavy metal contaminants in sediment of the Pearl River estuary. Chem. Spec. Bioavailability $12,17-25$.

Logananthan, B.G., and Kannan, K., (1994). Global Organochlorine contamination trends: an overview. Ambio 23, 187-191.

Long, E. R., Sloane, G. M., Scott, G. I., Thompson, B., Carr, R. S., Biedenbach, J., Wade, T. L., Presley, B. J., Scott, K. J., Mueller, C., Brecken-Fols, G., Albrecht, B., Anderson, J. W., Chandler, G. T. (1999). Magnitude and extent of chemical contamination and toxicity in sediments of Biscayne Bay and vicinity. NOAA Technical Memorandum NOS NCCOS CCMA 141, Silver Spring, Maryland.

MacDonald, D.D. (1994). Approach to the assessment of sediment quality in Florida coastal waters: Volume 1 - Development and evaluation of the sediment quality assessment guidelines. Report prepared for Florida Department of Environmental Protection. Tallahassee, Florida.

Manahan,S., E. (2000). Environmental Chemistry Seventh Edition. CRC Press LLC. 
Miles, C. J., Pfeuffer, R. J. (1997). Pesticides in canals of South Florida. Archives of Environmental Contamination and Toxicology, 32, 337-345.

Miller, R., and Mcpherson, B., (1998) Occurrence and Distribution of contaminants in bottom sediment and water of the Barron River Canal, Big Cypress National Preserve, Florida, October 1998. U.S. Department of the Interior, U.S. Geological Survey, Center for Coastal Geology. http:/sofia.usgs.gov/publications/papers/bottom sed.

National Oceanic and Atmospheric Administration-NOAA (1998). Sampling and analytical methods of the National Status and Trends Program Mussel Watch Project: 1993-1996 update. U.S. Department of Commerce, Silver Spring, Maryland.

National Oceanic and Atmospheric Administration-NOAA (1999) Magnitude and Extent of Chemical Contamination and toxicity in Sediments of Biscayne Bay and Vicinity.

Papagiannis, I., Kagalou, I., Leonardos, J., Petridis, D., Kalfakakou, V. (2004). Copper and zinc in four freshwater fish species from Lake Pamvotis (Greece). Environment International 30, 257-362.

Pfeuffer, R. J., (1985) Pesticide residue monitoring in sediment and surface water bodies within the South Florida Water Management District. South Florida Water Management District, Resource Planning Department, Water Chemistry Division. Technical Publication 85-2. West Palm Beach, Florida.

Pfeuffer, R. J., (1991) Pesticide residue monitoring in sediment and surface water bodies within the South Florida Water Management District Volume 2. South Florida Water Management District, Research and Evaluation Department, Water Quality Division. Technical Publication 85-2. West Palm Beach, Florida.

Science Subgroup, 1996. South Florida Ecosystem Restoration : Scientific Information Needs. Report to the Working Group of the South Florida Ecosystem Restoration Task Force. 487 pp.

Schmitt, C.J., ed. 2002, Biomonitoring of Environmental Status and Trends (BEST) Program: environmental contaminants and their effects on fish in the Mississippi River basin: U.S. Geological Survey, Biological Science Report 2002-0004, 241p.

Schropp S., Lewis, F., Windom, H., Ryan, J., Calder, F., and Burney, L. (1990) Interpretation of Metal Concentrations in estuarine sediments of Florida using aluminum as a reference element. Estuaries, 13(3):227-235. 
Schropp, S., and Windom, H. (1988) A guide to the interpretation of metal concentrations in estuarine sediments. Coastal Zone Management Section, Florida Department of Environmental Regulation, Tallahassee, Florida.

Scott, G. I., Fulton, M. H., Wirth, E. F., Chandler, G. T., Key, P. B., Daugomah, J. W., Bearden, D., Chung, K. W., Strozier, E. D., DeLorenzo, M., Sivertsen, S., Dias, A., Sanders, M., MaCauley, J. M., Goodman, L. R, LaCroix, M. W., Thayer, G. W., Kucklick, J. (2002. Toxicological studies in tropical ecosystems: an Ecotoxicological Risk Assessment of Pesticide Runoff in South Florida estuarine ecosystems. Journal of Agricultural and Food Chemistry 50, 44004408 .

Sheedy, B. R., Mattson, V. R., Cox, J. S., Kosian, P. A., Phipps, G. L., Ankley, G. T.(1998). Bioconcentration of polycyclic aromatic hydrocarbons by the freshwater oligochaete Lumbriculus variegates. Chemosphere 36, no. 15, 30613070 .

Thompson, S., Eglinton, G., (1978). The fractionation of a recent sediment for organic geochemical analysis. Geochimica et Cosmochimica Acta., 42, 199-207.

USACOE, (1999). Final Integrated Feasability Report and Programatic Environmental Impact Statement, Central and Southern Florida Project comprehensive review study. Jacksonville, Florida.

USEPA (2002). Proceedings and summary report: Workshop on the fate, transport, and transformation of mercury in aquatic and terrestrial environments. Mational Risk Management Research Laboratory, Office of Research and Development, U.S. Environmental Protection Agency, Cincinnati, $\mathrm{OH}$.

Valette-Silver, N. J., Riedel, G. F., Crecelius, E. A., Windom, H., Smith, R. F., Dolvin, S. S. (1999). Elevated arsenic concentrations in bivalves from the southeast coasts of the USA. Marine Environmental Research 48, 311-333.

Van der Oost, R., Opperhuizen, A., Satumalay, K., Heida, H., Vermeulen, N. P. E. (1996). Biomonitoring aquatic pollution with feral eel (Anguilla anguilla I. Bioaccumulation: biota-sediment ratios of PCBs, OCPs, PCDDs and PCDFs. Aquatic Toxicology 35, 21-46.

Van der Oost, R., Beyer, J., Vermeulen, N. P. E. (2003). Fish bioaccumulation and biomarkers in environmental risk assessment: a review. Environmental Toxicology and Pharmacology 13, 57-149.

Van der Weijden, C. H. (2002). Pitfalls of normalization of marine geochemical data using a common divisor. Marine Geology 184, 167-187. 
Van Dijk, H. F. G., Guicherit, R. (1999). Atmospheric dispersion of current-use pesticides: a review of the evidence from monitoring studies. Water, Air, and Soil Pollution 115, 21-70.

Verweij, F., Booij, K., Satumalay, K., Van der Molen, K., Van der Oost, R. (2004). Assessment of bioavailable $\mathrm{PAH}, \mathrm{PCB}$ and $\mathrm{OCP}$ concentrations in water, using Semipermeable membrane devices (SPMDs), sediments and caged carp. Chemosphere 54, $1675-1689$.

Wade, T. L., Atlas, E. L., Brooks, J. M., Kennicutt II, M.C., Fox, R. G., Sericano, J., Garcia-Romero, B., Defreital, D. (1988). NOAA Gulf of Mexico Status and Trends Program: Trace organic contamination distribution in sediements and oysters. Estuaries 11, no. 3, 171-179.

Wania, F., Daly, G. L. (2002). Estimating the contribution of degradation in air and Deposition to the deep sea to the global loss of PCBs. Atmospheric Environment, 36, 5581-5593. 
APPENDICES 
APPENDIX I. Chemical Structure of Organochlorine Pesticides

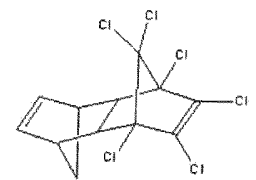

Aldrin

C12H8Cl6 M.W.364.9132<smiles>C=C(OCC)Oc1nc(Cl)c(Cl)cc1Cl</smiles>

Chlorpyrifos

$\mathrm{C}_{9} \mathrm{H}_{11} \mathrm{Cl}_{3} \mathrm{NO}_{3}$ PS M.W. 350.58356<smiles>ClC(Cl)=C(c1ccc(Cl)cc1)c1ccccc1Cl</smiles>

DDE OP

$\mathrm{C}_{14} \mathrm{H}_{8} \mathrm{Cl}_{4} \quad$ M.W. 318.0292<smiles>Clc1ccc(C(c2ccc(Cl)cc2)C(Cl)(Cl)Cl)cc1</smiles>

DDT PP

$\mathrm{C}_{1 .} \mathrm{H}_{0} \mathrm{Cl}_{5} \quad$ M.W.354.4901<smiles>O=C1COCC2C3(Cl)C(Cl)=C(Cl)C2(Cl)C1(Cl)C3(Cl)Cl</smiles>

Endosulfan-II

$\mathrm{C}_{9} \mathrm{H}_{6} \mathrm{Cl}_{6} \mathrm{O}_{3} \mathrm{~S} \quad$ M.W. 406.9226

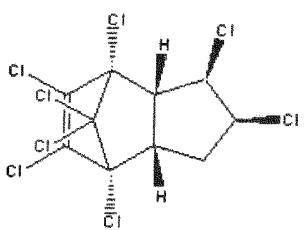

cis-chloradane

$\mathrm{C}_{10} \mathrm{H}_{6} \mathrm{Cl}_{8} \quad$ M.W. 409.7814<smiles>Clc1ccc(C(c2ccccc2Cl)C(Cl)Cl)cc1</smiles>

DDD OP

C14H10Cl4 M.W. 320.045<smiles>ClC(Br)=C(c1ccc(Cl)cc1)c1ccc(Cl)cc1</smiles>

DDE PP

$\mathrm{C}_{14} \mathrm{H}_{8} \mathrm{Cl}_{4} \quad$ M.W. 318.0292

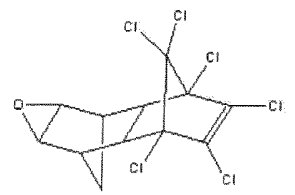

Dieldrin

$\mathrm{C}_{12} \mathrm{H}_{8} \mathrm{Cl}_{6} \mathrm{O} \quad$ M.W. 380.9126

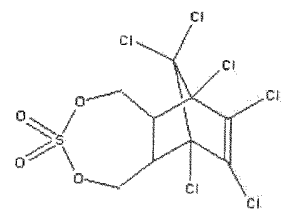

Endosulfane sulfate

$\mathrm{C}_{9} \mathrm{H}_{6} \mathrm{Cl}_{6} \mathrm{O}_{4} \mathrm{~S} \quad \mathrm{M} . \mathrm{W} .422 .922$

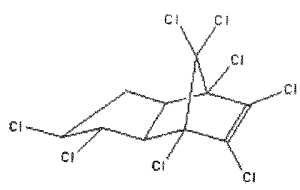

gamma-chlordane

$\mathrm{C}_{10} \mathrm{H}_{6} \mathrm{Cl}_{8}$ M.W.409.7814<smiles>Oc1ccc(C(c2ccc(Cl)cc2)C(O)Cl)cc1</smiles>

DDD PP

$\mathrm{C}_{14} \mathrm{H}_{10} \mathrm{Cl}_{4} \quad$ M.W. 320.045<smiles>Clc1ccc(C(c2ccccc2Cl)C(Cl)(Cl)Cl)cc1</smiles>

DDT OP

$\mathrm{C}_{14} \mathrm{H}_{9} \mathrm{Cl}_{5}$ M.W. 354.4901

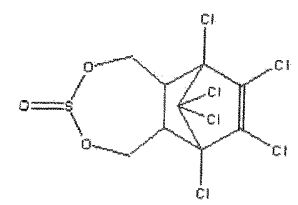

Endosulfan-I

$\mathrm{C}_{9} \mathrm{H}_{6} \mathrm{Cl}_{6} \mathrm{O}_{3}$ S M.W.406.9226

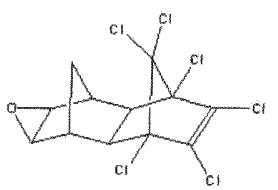

Endrin

C12H8Cl6O M.W.380.9126 


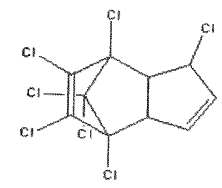

Heptachlor

$\mathrm{C}_{10} \mathrm{H}_{5} \mathrm{Cl}_{7}$ M.W. 373.3205<smiles>Clc1cc(Cl)c(Cl)c(Cl)c1Cl</smiles>

Pentachlorobenzene

C6HCl5 M.W.250.3389

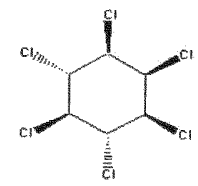

delta-Hexachlorocyclohexane C6H6Cl6 M.W. 290.8314

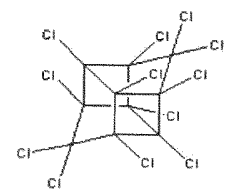

Mirex

$\mathrm{C}_{10} \mathrm{Cl}_{12}$ M.W. 545.546

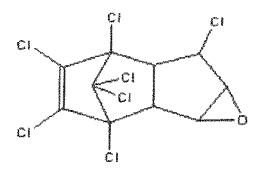

Heptachlor epoxide $\mathrm{C}_{10} \mathrm{H}_{5} \mathrm{Cl}_{7} \mathrm{O}$ M.W. 389.3199<smiles>C[C@H]1[C@H](Cl)[C@H](Cl)[C@H](Cl)[C@H](Cl)[C@H]1Cl</smiles>

alpha-hexachlorocyclohexane $\mathrm{C}_{6} \mathrm{H}_{6} \mathrm{Cl}_{6}$ M.W. 290.8314

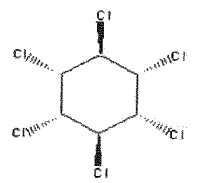

Lindane (gamma-HCH)

$\mathrm{C}_{6} \mathrm{H}_{6} \mathrm{Cl}_{6} \quad$ M.W.290.8314<smiles>Clc1ccc(Cl)c(Cl)c1Cl</smiles>

1,2,3,4-Tetrachlorobenzene $\mathrm{C}_{6} \mathrm{H}_{2} \mathrm{Cl}_{4} \quad$ M.W. 215.8938

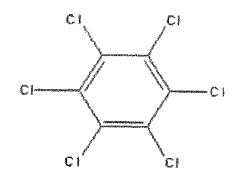

Hexachlorobenzene $\mathrm{C}_{6} \mathrm{Cl}_{6}$ M.W. 284.784<smiles>C[C@H]1[C@H](Cl)[C@H](Cl)[C@H](Cl)[C@H](Cl)[C@H]1Cl</smiles>

beta-hexachlorocyclohexane $\mathrm{C}_{6} \mathrm{H}_{6} \mathrm{Cl}_{6}$ M.W. 290.8314<smiles>COc1ccc(C(c2ccc(OC)cc2)C(Cl)(Cl)Cl)cc1</smiles>
Metoxychlor $\mathrm{C}_{16} \mathrm{H}_{15} \mathrm{Cl}_{3} \mathrm{O}_{2}$ M.W. 345.6523

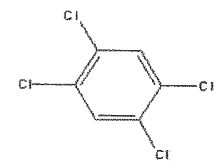

1,2,4,5-Tetrachlorobenzene $\mathrm{C}_{6} \mathrm{H}_{2} \mathrm{Cl}_{4} \quad$ M.W. 215.8938 
APPENDIX II. Chemical Structure of Polychlorinated Biphenyls

PCBs have the chemical formula $\mathrm{C}_{12} \mathrm{H}_{10-n} \mathrm{Cl}_{n}$, where $\mathrm{n}=1-10$ (Figure 1).

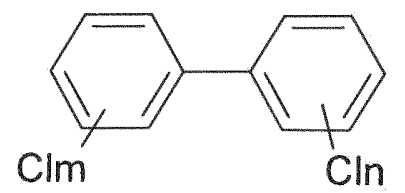

$m+n=1$ to 10 
APPENDIX III. Chemical Structure of Polycyclic Aromatic Hydrocarbons<smiles>c1ccc2ccccc2c1</smiles>

Naphthalene

C10H8 M.W. 128.2<smiles>c1cc2c3c(cccc3c1)CC2</smiles>

Acenaphthene

C12H10 M.W. 154.2

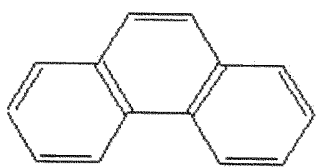

Phenanthrene

C14H10 M.W. 178.2<smiles></smiles>

Fluoranthene

C16H10 M.W. 202.2<smiles>c1ccc2c(c1)ccc1c3ccccc3ccc21</smiles>

Chrysene

C18H12 M.W. 228.3<smiles>c1ccc(-c2ccccc2)cc1</smiles>

Biphenyl C12H10 M.W. 154.2<smiles>c1ccc2c(c1)Cc1ccccc1-2</smiles>

Fluorene

C13H10 M.W. 166.2<smiles>c1ccc2cc3ccccc3cc2c1</smiles>

Anthracene

C14H10 M.W. 178.2

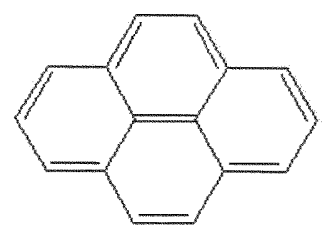

Pyrene

C16H10 M.W. 202.2

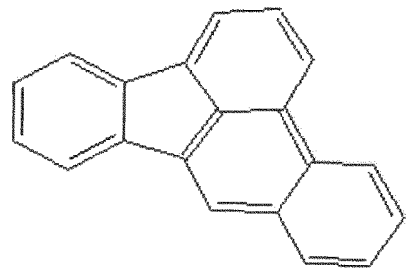

Benzo(b)fluoranthene

C20H12 M.W. 252.3<smiles>C1=Cc2cccc3cccc1c23</smiles>

Acenaphthylene C12H8 M.W. 152.2<smiles>c1ccc2c(c1)sc1ccccc12</smiles>

Dibenzothiophene C12H8S M.W. 184.2<smiles>c1ccc2c(c1)[nH]c1ccccc12</smiles>

Carbazole C12H9N M.W. 167.2<smiles>c1ccc2cc3c(ccc4ccccc43)cc2c1</smiles>

Benz(a)anthracene

C18H12 M.W. 228.2

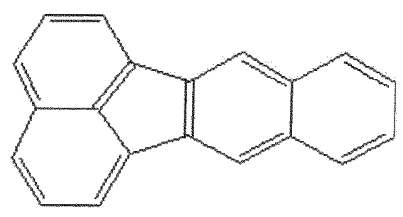

Benzo(k)fluoranthene C2OH12 M.W. 252.3 


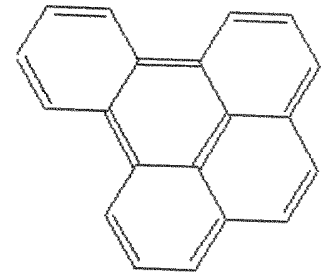

Benzo(e)pyrene

C20H12 M.W. 252.3<smiles>c1ccc2c(c1)ccc1cc3c(ccc4ccccc43)cc12</smiles>

Dibenz[a,h]anthracene

C22H14 M.W. 278.3<smiles>Cc1ccc2ccccc2c1</smiles>

2-methylnaphtalene C11H10 M.W. 142.2<smiles>Cc1cc2cccc(C)c2cc1C</smiles>

1,6,7-trimethylnapthalene C13H14 M.W. 170.2<smiles>c1ccc2c(c1)cc1ccc3cccc4ccc2c1c34</smiles>

Benzo(a)pyrene

C20H12 M.W. 252.3<smiles></smiles>

Benzo[g,h,I]perylene

C22H12 M.W. 276.3<smiles>Cc1cccc2ccccc12</smiles>

I-methylnaphtalene C11H10 M.W. 142.2<smiles>Cc1cccc2c1ccc1ccccc12</smiles>

1-methylphenanthrene C15H12 M.W. 192.2<smiles></smiles>

Indeno[1,2,3-cd]pyrene C22H12 M.W. 276.3

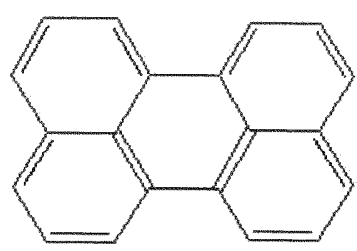

Perylene

C20H12 M.W. 252.3<smiles>Cc1ccc2cc(C)ccc2c1</smiles>

2,6-dimethylnapthalene C12H12 M.W. 156.2 